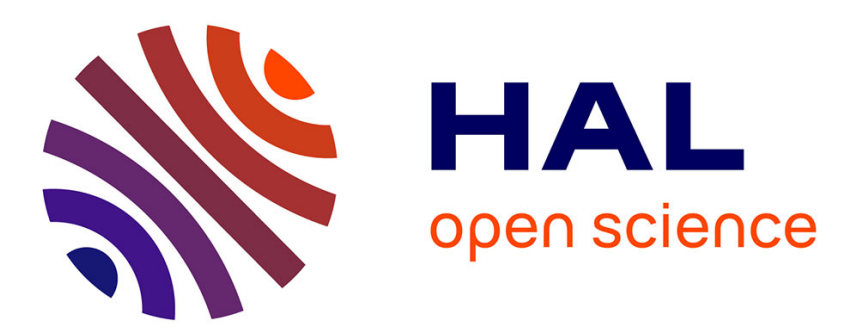

\title{
Mesozoic evolution of NW Africa: implications for the Central Atlantic Ocean dynamics
}

\author{
Rémi Leprêtre, Jocelyn Barbarand, Yves Missenard, Cécile Gautheron, \\ Rosella Pinna-Jamme, Omar Saddiqi
}

\section{- To cite this version:}

Rémi Leprêtre, Jocelyn Barbarand, Yves Missenard, Cécile Gautheron, Rosella Pinna-Jamme, et al.. Mesozoic evolution of NW Africa: implications for the Central Atlantic Ocean dynamics. Journal of the Geological Society, 2017, 174 (5), pp.817 - 835. 10.1144/jgs2016-100 . hal-01676091

\section{HAL Id: hal-01676091 https: / hal.sorbonne-universite.fr/hal-01676091}

Submitted on 5 Jan 2018

HAL is a multi-disciplinary open access archive for the deposit and dissemination of scientific research documents, whether they are published or not. The documents may come from teaching and research institutions in France or abroad, or from public or private research centers.
L'archive ouverte pluridisciplinaire HAL, est destinée au dépôt et à la diffusion de documents scientifiques de niveau recherche, publiés ou non, émanant des établissements d'enseignement et de recherche français ou étrangers, des laboratoires publics ou privés. 


\section{Mesozoic evolution of Northwest Africa: implications for the Central Atlantic Ocean dynamics}

Rémi Leprêtre ${ }^{1,2, *}$, Jocelyn Barbarand ${ }^{1}$, Yves Missenard ${ }^{1}$, Cécile Gautheron ${ }^{1}$, Rosella Pinna-Jamme ${ }^{1}$, Omar Saddiqi $i^{3}$

${ }^{1}$ Université Paris Sud-XI, Paris-Saclay, GEOPS, UMR 8148, Bâtiment 504, rue du Belvédère, F-91405, Orsay, France

${ }^{2}$ Université Pierre et Marie Curie Paris-VI, ISTeP, UMR 7193, EMBS, 4 place Jussieu, 75005, Paris, France

${ }^{3}$ Université Hassan II, Faculté des Sciences, 20000, Casablanca 20000, Morocco *Correspondence (remi.lepretre@upmc.fr, remi.lep@gmail.com)

Abbreviated title: Mesozoic Evolution of NW Africa

\section{Abstract}

The Central Atlantic Ocean opened during the Early Jurassic and represents the oldest portion of the Atlantic Ocean. Although the American margin has been well-studied, the onshore evolution of its African counterpart is poorly understood. We investigated the evolution of a 1300 $\mathrm{km}$ transect across the Reguibat Shield (Morocco, Mauritania, Algeria) in the northern West African Craton using low-temperature thermochronology. Fourteen samples were dated using apatite fission-track analysis. Nine of these samples were also dated using (U-Th-Sm)/He analysis. Fissiontrack ages range from $118 \pm 10$ to $497 \pm 61 \mathrm{Ma}$, with mean track lengths between $11.2 \pm 0.4$ and 12.5 $\pm 0.2 \mu \mathrm{m}$. (U-Th-Sm)/He single-grain ages range from $32 \pm 3 \mathrm{Ma}$ to $396 \pm 32 \mathrm{Ma}$. Through forward and inverse thermal modeling, we demonstrate that the craton underwent kilometric exhumation between the Early-Middle Jurassic and the Late Cretaceous. Based on our new results, published data on Northwest Africa and data from the conjugate eastern North American passive margin, we show that this post-rift Early-Middle Jurassic/Early Cretaceous exhumation affected both margins in a 
31 similar areal extent and simultaneously. Transient mantle dynamic support is suggested as 32 accounting for the major erosional phase recorded on both margins.

Supplementary material: methodology for thermal modeling, individual thermal modeling for all samples and the relationship between apatite chemistry and (U-Th)/He ages are available at https://figshare.com/s/05461f8ec0de274456c6

Keywords

Low-temperature thermochronology - West African Craton - Central Atlantic Ocean - post-rift evolution of passive margin - Reguibat Shield

40 


\section{Introduction}

In the past two decades, substantial evidence has been presented to show that passive margins are anything but passive. For example, the Atlantic-type margins have been thoroughly studied and show repeated uplift or burial events in the course of their post-rift history (Gallagher et al., 1998; Turner et al., 2008; Holford et al., 2009; Japsen et al., 2006, 2012; Cogné et al., 2012; Green et al., 2013; Leprêtre et al., 2015; Wildman et al., 2015). These studies have demonstrated that the precise determination of the timing of burial/uplift phase of the onshore margins can offer a better understanding of the stratigraphical record along the margins (Japsen et al., 2012). Despite the evidence that passive margins are active features in plate tectonics, these studies also highlight the poor knowledge we have on the underlying mechanisms controlling these processes (Japsen et al., 2012; Green et al., 2013 and references therein).

In order to better understand the underlying mechanisms controlling rift and post-rift evolution, it is necessary to assess the simultaneous uplift/burial events on conjugate passive margins (e.g. Turner et al., 2008; Green \& Duddy, 2010). In this study, we compare the stratigraphical record of the conjugate margins of the Central Atlantic Ocean during the Mesozoic and the vertical evolution of the onshore domains. These margins have received considerable attention in the past (eastern North America: Sheridan \& Grow, 1988; Miall, 2008; Northwest Africa: von Rad et al., 1982; Poag \& Schlee, 1984), although there have been a limited number of comparison studies focusing on their respective stratigraphical records (Jansa \& Wiedmann, 1982; von Rad \& Sarti, 1986) and no study has ever compared the two margins considering their onshore evolutions. Many lowtemperature thermochronology studies have been undertaken along the onshore eastern North American passive margin (Crowley, 1991; Wang et al., 1994; Boettcher \& Milliken, 1994; Roden-Tice et al., 2000; Roden-Tice \& Wintsch, 2002; Grist \& Zentilli, 2003; Lorencak et al., 2004; Spotila et al., 2004; Roden-Tice \& Tice, 2005; Taylor \& Fitzgerald, 2011; Roden-Tice et al., 2012). However, along the Northwest African passive margin, a similarly large coverage of onshore data is still lacking (first 
data in Leprêtre et al., 2014 and 2015) to achieve a detailed comparison of both margins and addressing this issue is a major goal of this study.

This study reports low-temperature thermochronology (LTT) data across the whole range of the northern West African Craton, which is the main continental domain of the eastern Central Atlantic Ocean (Fig. 1a). We used apatite fission-track and (U-Th-Sm)/He (AFT and AHe, respectively) LTT and thermal modeling techniques (Gallagher, 2012) to constrain the timing and amplitude of erosion/burial events for Mesozoic-Cenozoic times. Given a $40-120^{\circ} \mathrm{C}$ thermal sensitivity, these methods provide insights into the evolution of the uppermost 3-4 km of the crust (Gallagher et al., 1998; Flowers et al., 2009; Gautheron et al., 2009, Djimbi et al., 2015). We then combine our new LTT study with the wealth of LTT data on the eastern American passive margin and the sedimentary records of both conjugate passive margins. These data form the basis of our comparison between the two margins and discussion of the Mesozoic evolution of the Central Atlantic Ocean.

\section{Geological setting}

Within the northern West African Craton (NWAC), the Reguibat Shield is a flat basement domain, divided into a western Archean domain (> 2.5 Ga; Potrel et al., 1998; Schofield et al., 2012) and an eastern Eburnean domain (2-2.2 Ga; Lahondère et al., 2001; Peucat et al., 2005). Its westernmost tip is part of the Variscan Mauritanides (Villeneuve, 2008; Michard et al., 2010). North and south of the Reguibat Shield, the Tindouf and Taoudeni basins display a km-scale Paleozoic infill (Boote et al., 1998), unconformably lying on the Neoproterozoic rocks (Fig. 1b). Both basins have large-scale synclinal shapes with low $\left(5-10^{\circ}\right)$ dipping flanks, with the exception of the steeper northern flank of the Tindouf Basin, which was involved in the Variscan deformation (Burkhard et al., 2006). Most authors acknowledge the existence of a continuous sedimentary realm until the Early Carboniferous (Bertrand-Sarfati et al., 1991; Legrand-Blain \& Perret-Mirouse, 2000). On top of 
Paleozoic formations, unconformable horizontal Mesozoic-Cenozoic formations are observed. The oldest Mesozoic deposits are Early Cretaceous rocks in the Tindouf Basin (Gevin, 1960; Fabre, 2005). In the eastern Taoudeni Basin (Tanezzrouft), the oldest Mesozoic deposits are possibly Late Cretaceous (Fabre et al., 1996) (Fig. 1). This hiatus of more than 100 Myr (from Late Carboniferous/Permian to at least Early Cretaceous) differentiates the WAC from the central and eastern Sahara domains where post-Variscan deposits can be as old as Triassic in central Sahara (Busson, 1972; Boudjema, 1987).

The Tarfaya-Laayoune-Dakhla Basin (TLDB; Fig. 1b) is a NE-SW oriented basin which bounds the Atlantic Ocean. This basin formed during the opening of the Central Atlantic Ocean, with an estimated break-up in the Late Sinemurian ( 190 Ma; Labails et al., 2010). The basin is built on a 100$\mathrm{km}$ wide stretched crustal domain with a crust thickness that varies from 27 to $7 \mathrm{~km}$ oceanward (Klingelhoefer et al., 2009). The thick Mesozoic-Cenozoic infill reaches more than $10 \mathrm{~km}$ (AUXINI, 1969; Martinis \& Visintin, 1966; Ratschiller, 1968; Ranke et al., 1982; Fig. 1c) and represents a reliable record of the large-scale changes, which occurred during that time. On top of Triassic clasticevaporitic deposits, the Middle-Late Jurassic witnesses the build-up of a large carbonate platform that ended in the Neocomian (up to the Barremian). The margin was then buried under unconformable km-scale continental clastic deposits before marine conditions resumed in AptianAlbian and continued during the Late Cenomanian-Turonian times. The early Paleogene environment was still marine but characterized by shallower depths before becoming continental from the Eocene onwards. Paleogene formations lie unconformably on the Early and Late Cretaceous in TLDB. Neogene deposits are scarce, thin and usually continental.

\section{Sampling and methodology}


116 LTT transect of the NWAC from the Atlantic passive margin to the Panafrican suture in the east. Our new data adds two AFT data to the 11 existing AFT data in the western Reguibat Shield (Leprêtre et al., 2015), four new AFT and three new AHe datasets to the existing four AFT and one AHe datasets (Leprêtre et al., 2014) and eight new AFT and 6 new AHe datasets for the eastern Reguibat Shield (Fig. 1b). For the reader's information, the complete dataset encompassing samples from Leprêtre et al. $(2014,2015)$ are presented in Supplementary data (Tables S1, S2). results. With the exception of one AFT age (256 Ma from TEN1153 sample, in central Reguibat Shield), AFT age ranges largely overlap between western and central domains (Fig. 2). Mean track lengths (MTLs) are also comparable between these two domains whereas MTLs from the eastern domain are shorter (Fig. 3). Western and central Reguibat Shield domains are differentiated based on their AHe age ranges. AHe ages from western Reguibat Shield are younger than $127 \mathrm{Ma}$ (only one replicate is older) whereas they range from 38 to $191 \mathrm{Ma}$ for central Reguibat Shield (4 of 11 AL10 replicates are out of the trend) with significantly older AHe ages at eU $>20 \mathrm{ppm}$. Compared to central Reguibat Shield (AFT range: 139 to $256 \mathrm{Ma}$; AHe range: 38 to 269 Ma when excluding the two anomalously old AL10 replicate; see Table 2), eastern Reguibat Shield yielded significantly older AFT ages (237 to $497 \mathrm{Ma}$ against 139 to $256 \mathrm{Ma}$ for central Reguibat; Table 1; Fig. 2, 3) and shows a larger scattering of the AHe data ( 32 to $384 \mathrm{Ma}$ ).

Low-temperature thermochronology dating was carried out using the external detector method (Gleadow \& Duddy, 1981) for calculating the central age (Galbraith \& Laslett, 1993) using the Zeta calibration (Hurford \& Green, 1983). Zeta 
(Hurford, 1990; $\zeta=368 \pm 10$ for RL). Neutron irradiation was carried out at Garching facility

141 (Germany). Spontaneous tracks were revealed by etching in $5 \mathrm{M} \mathrm{HNO}_{3}$ for 20 seconds at $20 \pm 1^{\circ} \mathrm{C}$. The

142 size of the etch pit made between the track and polished apatite surface (Dpar) was measured and used as a kinetic parameter for fission track annealing (Carlson et al., 1999). Dpar measurements act as a proxy for compositional and structural variations in apatite (Barbarand et al., 2003). Horizontal confined track-lengths were measured using a LEICA microscope with a x1000 magnification and a digitizing tablet linked via a drawing tube to the microscope. AFT ages, lengths and Dpar measurements are given in Table 1 and figures 2-4.

AHe analysis was carried out on euhedral inclusion-free apatite crystals with a minimum of four replicates per sample. Crystal dimensions and geometry were measured along the three axes and grains were placed into a platinum basket. Ejection factors and sphere equivalent radius were determined using the Monte Carlo simulation from Ketcham et al. (2011). More details on He, U, Th and Sm content determination can been found in Gautheron et al. (2013). The analysis was calibrated using internal and external age standards (Durango: McDowell et al., 2005; Limberg Tuff: Kraml et al., 2006). The error on the AHe age at $1 \sigma$ is estimated to be a maximum of $8 \%$ reflecting uncertainty in the ejection factor (FT) correction and standard dispersion. The final He, U-Th-Sm content and AHe age are reported in Table 2. the cooling rate and on He diffusion coefficient. It has been shown that a pure apatite crystal "freedefault crystals" yield closure temperature of c.a. $30-40^{\circ} \mathrm{C}$ depending on chemical content (Djimbi et al., 2015). For natural apatite, the closure temperature is tightly linked to the alpha-recoil damage fraction (Shuster et al., 2006; Shuster \& Farley, 2009). This behavior has been incorporated into two predictive models by Flowers et al. (2009) and Gautheron et al. (2009). These models consider that recoil damage annealing follows kinetics similar to fission-tracks, after the results of Ketcham et al. 164 (2007). Different closure temperatures can be monitored through the relationship of AHe age vs. 
efficient uranium (eU). The eU represents the amount of radioactive elements contributing to the ${ }^{4} \mathrm{He}$ production and its amount controls the closure temperature for a given thermal history (Shuster et al., 2006). Thus, scattered AHe ages emphasize, at first order, differences in AHe closure temperatures between replicates in the same sample. Moreover, the damage-annealing rates can be influenced by the apatite chemistry (Gautheron et al., 2013; Djimbi et al., 2015). In particular, Gautheron et al. (2013) demonstrated that complex thermal histories in slow moving geological settings can greatly enhance the scattering in the data given the chemistry differences between grains. Also, the ${ }^{4} \mathrm{He}$ apatite content can increase through implantation from rich eU neighbors crystals in the rock (Spiegel et al., 2009; Gautheron et al., 2012) or for low eU apatite, this effect has also been observed (Kendra et al., 2013; Murray et al., 2014; Janowski et al., 2017). Helium implantation produces an artificial aging trend for the more exposed apatite crystals. In addition, the analysis of broken apatite crystals can add scattering to the data (Brown et al., 2013).

\section{Thermal modeling}

\section{Modeling procedure}

Inverse thermal modeling was performed using the software QTQt (Gallagher, 2012) while HeFTy (Ketcham, 2005) was used for forward modeling. We used the fission track annealing kinetics of Ketcham et al. (2007) and the He-trapping/diffusion model of Flowers et al. (2009). The Flowers et al. (2009) radiation damage accumulation and annealing model is empirically calibrated and is not well-representative of the physical processes of diffusion compared to the Gautheron et al. (2009) model but it gives better predictions, mainly for low-eU apatite $(<20$ ppm; majority of our samples, see Table 2). QTQt works with a probabilistic Bayesian approach for inverse modeling. It samples numerous thermal histories and from them builds a population of models selected according to the degree of agreement between data and model-this is the burn-in phase. It then proceeds with inverse modeling, which is called the post burn-in phase. For each phase, the user can choose the 
number of iterations, depending on the complexity of its own data set. In QTQt, the fit between the data and the model is defined by the Log Likelihood (LL; details are given in Gallagher, 2012).

\section{Strategy for thermal modeling}

The strategy for the thermal modeling of the LTT data relies on the geological context of the study. Importantly for this study, we consider, following Burov (2011), that deformation of old lithospheres (> 1Ga) is mostly controlled by the rheology of the lithosphere which is dependent on its age. The Reguibat Shield is an old lithosphere (> 2 Ga; Potrel et al., 1998; Lahondère et al., 2001; Peucat et al., 2005; Schofield et al., 2012; Bea et al., 2013) and as such, its deformation will involve the whole lithosphere with wavelengths $>500 \mathrm{~km}$. We thus infer that samples separated from each other by less than few hundred kilometers should behave coherently and share similar thermal paths. Furthermore, it implies that stratigraphical unconformities located on the boundaries of the Reguibat Shield can give precious information for the evolution of its basement since the latter is rarely wider than $400 \mathrm{~km}$ (Fig. 1).

For eastern Reguibat Shield, two major stratigraphical constraints were used: (1) unconformable Cambrian deposits on the NWAC basement (Trompette, 1973; Deynoux, 1980 for Taoudeni Basin; Boote et al., 1998 for Tindouf Basin); (2) unconformable poorly-dated upper Cretaceous deposits on the eastern boundary of the Reguibat basement. We used a large temperature box $\left(20-180^{\circ} \mathrm{C}\right)$ for the $470-230 \mathrm{Ma}$ interval as no constrain exists for this period. Firstly, a general thermal path was modeled with inverse modeling for eastern Reguibat shield samples that have both AFT and AH data (Fig. 6a-c, 7a; Fig. S2-7). By combining AFT and AHe datasets, we can achieve a better resolution of the thermal history path. The important temperature/time (or $(T, t))$ nodes obtained in this first modeling were used as constraints for other eastern Reguibat Shield samples where only AFT data were available ( $\mathrm{CH} 2$ and DEG6, Fig. S2-3). Only final models are presented in the results (Fig. 6a, 7a). Considering the old LTT ages of samples from eastern Reguibat 
Shield (> $237 \pm 21 \mathrm{Ma}$ ), we only used the constraint that rocks were at surface during Cambrian. In the course of thermal modeling, no stable solutions were obtained for samples GH20 and IG3. on the basement in the east of the TLDB (Fig. 1b). This Lower Cretaceous unconformity is distant from the samples by less than $400 \mathrm{~km}$. We suggest that it likely implies that even samples from the interior of the Reguibat Shield were at or close to the surface at this time. We used here a two-step approach for thermal modeling.

Firstly, we carried out a phase of forward modeling to explain the AHe age-eU positive correlation (Fig. 5b, 8). In this phase, we consider the AHe data of all samples as these data should behave coherently given that they are restricted to cratonic areas and the entire AHe dataset samples a larger eU range than any one sample. Various thermal paths were tested to check their AHe predictions and compare them to the measured data. Given that the AFT ages are all younger than $250 \mathrm{Ma}$, the tested thermal history paths are chosen in order to display cooling initiated by the Early Jurassic. Using the initial forward modeling step, we have identified the scenarios that best explain the observed AHe data. These scenarios yield $(T, t)$ constraints, i.e. compulsory nodes in the $(T, t)$ space through which the thermal path must go to fit the AHe age-eU relationship. Secondly, we then performed inverse modeling that included these $(T, t)$ constraints, so as to investigate the degree of freedom left to fit the AFT data. The same stratigraphic constraint was used for all samples. All detailed individual models are presented figures $\$ 8-15$ and only the final thermal paths are presented in figure $7 \mathrm{~b}$.

The two new samples from the western Reguibat Shield were modeled using the $(T, t)$ constraints determined in Leprêtre et al. (2015) (Fig. S16-17 and Text S1). One detailed thermal modeling is presented in figure $6 \mathrm{c}$ and all thermal paths for the western Reguibat Shield are shown in figure $7 c$. 
2009; Gautheron et al., 2009), we advocate that for a given thermal history path, single-grain AHe ages are expected to display a correlation with eU. As a methodological consequence for our thermal modeling, we removed the single-grain AHe ages that were outliers from the mean AHe age-eU correlation, i.e. in our samples, being outliers by more than 50-100 Ma or a very different eU value (e.g. Flowers and Kelley, 2011). Using these "outlier" replicates would impede the thermal modeling as the model would attempt to fit out-of-trend data and lead to either no acceptable solutions being found (in the case of HeFTy) or to a thermal model with bad fit for many replicates (e.g. QTQt, Fig. S1). A clear assumption is made here that favors an acceptable goodness of fit for the majority of replicates, which belong to a common AHe age-eU trend, instead of trying to explain all the replicates resulting in a poor fit between predicted and observed data. Following this criteria, one single-grain $\mathrm{AHe}$ age of nine was removed in sample $\mathrm{CH} 1$ and TL3 for being too far from the mean AHe age-eU correlation (Fig. 5d, i; Table 2). Also, 3 of 11 replicates were removed in sample AL10 for the same reason (Fig. S1).

\section{Results}

The new and published AFT and AHe ages presented for 29 samples give the first comprehensive dataset across the whole Reguibat Shield. Based on the data location and their thermal histories, the studied area has been divided into western, central and eastern domains. Published data from the western and central Reguibat Shield (Leprêtre et al., 2014; 2015) are only briefly summarized, but the complete Reguibat dataset is presented together in Tables S1 and S2. 
and $12 \pm 0.2 \mu \mathrm{m}$ (Fig. 3). Track length disributions (TLDs) are largely unimodal and spread around the mean (Fig. 4). Dpar measurements range from $1.7 \pm 0.2$ to $2.1 \pm 0.2 \mu \mathrm{m}$. AHe ages corrected from alpha ejection range from $32 \pm 3$ to $384 \pm 31 \mathrm{Ma}$ with eU contents that range from 2 to $32 \mathrm{ppm}$. No clear trend in the AHe age vs. eU plot exists (Fig. 5a) and the very variable AHe ages for similar eU contents suggest that process other than a variable diffusion coefficient. This process will be discussed later.

In the central Reguibat Shield, new AFT ages range from $150 \pm 8$ to $202 \pm 14 \mathrm{Ma}$ (Table 1 ) and are in agreement with published data (139 \pm 9 to $256 \pm 21$ Ma; Leprêtre et al., 2014). New MTLs range from $11.4 \pm 0.3$ to $12.0 \pm 0.2 \mu \mathrm{m}$ and are undistinguishable from the $11.9 \pm 0.2$ to $12.4 \pm 0.2 \mu \mathrm{m}$ range for published data (Fig. 3, 4). Dpar measurements range from $1.6 \pm 0.2$ to $2.1 \pm 0.5 \mu \mathrm{m}$. AHe ages corrected from alpha ejection range from $38 \pm 3$ to $396 \pm 32 \mathrm{Ma}$ (Table 2) with eU content ranging from 7 to $83 \mathrm{ppm}$. Overall, they are younger than AFT ages with the exception of some replicates from samples AL10 and TGH3163. AHe age vs. eU plot shows a general positive correlation (Fig. 5b).

In the western Reguibat Shield, the two new samples yielded AFT ages of $137 \pm 12 \mathrm{Ma}$ and $118 \pm 10$ Ma with no measurable confined lengths (Table 1). Published AFT ages range from $107 \pm 8$ to $175 \pm 16 \mathrm{Ma}$, with mean track length (MTL) ranging from $11.8 \pm 0.2 \mu \mathrm{m}$ to $12.5 \pm 0.2 \mu \mathrm{m}$ (Leprêtre et al., 2015). Track length distributions (TLDs) are largely unimodal, slightly spread around the mean with some complex shapes but for samples with few confined lengths (Fig. 3, 4). Dpar measurements range from $1.5 \pm 0.2$ to $1.8 \pm 0.3 \mu \mathrm{m}$. Overall, AFT ages are quite homogenous, with a mean around 130-140 Ma. All AFT ages are younger than the 190 Ma rifting (Labails et al., 2010). AHe ages corrected from the alpha-ejection range from $14 \pm 1 \mathrm{Ma}$ to $185 \pm 15 \mathrm{Ma}$, with an eU content ranging from 7 to $71 \mathrm{ppm}$. AHe age vs. eU plot shows positive correlations when samples are grouped by region (Fig. 5c) and these $\mathrm{AHe}$ age-eU relationships reflect thermal histories with successive reheating/cooling events (Leprêtre et al., 2015). Lepretre et al. (2015) demonstrated that AHe age 
scattering within each data set could be explained by radiation damage effects with a secondary role played by variations in apatite chemistry.

\section{Thermal modeling results}

For each domain of the Reguibat Shield, we present one representative thermal model with all predicted vs. measured AFT and AHe data (Fig. 6). All individual models are presented in detail in the supplementary data (Fig. S2-S17).. A synthesis with all the thermal paths is given in figure 7. The models for western Reguibat Shield are highly dependent on the constraints determined by Leprêtre et al. (2015) as neither AHe nor length data are available for the two new samples (Fig. 6g-h).

Sample GH3 illustrates the general shape of the thermal paths for the eastern Reguibat Shield (Fig. 1b, 6a-c). Thermal paths obtained from the inverse modeling for 6 of the 8 samples of this domain are presented in figure 7a. For the best constrained, double LTT dated samples (TL3, GH3, $\mathrm{CH} 1$ and $\mathrm{CH} 3$ ), thermal paths show a major cooling episode during the Early Cretaceous. This cooling is variable among samples. At the very end of the Jurassic, samples were generally at temperatures higher than $60^{\circ} \mathrm{C}$ (except for TL3) and were not undergoing cooling. Results are similar for AFT-dated samples $\mathrm{CH} 2$ and DEG6. Whereas the western and central domains suffered post-Early Cretaceous reheating, samples from the eastern domain cooled by $30 \pm 10^{\circ} \mathrm{C}$ and stayed at relatively low temperatures up to the present-day.

For the central Reguibat Shield, the forward modeling with AHe datasets clearly favored the scenario involving the occurrence of a Jurassic-Early Cretaceous cooling event followed by a lowamplitude reheating step (Fig.8; Table S3). Five forward scenarios were tested: a small Middle Jurassic-Lower Cretaceous cooling with stable thermal conditions during Late Cretaceous (HT1); a large Jurassic-Early Cretaceous cooling $\left(>40^{\circ} \mathrm{C}\right)$ bringing samples close to the surface (HT2 and HT3) before reheating episode; a continuous slow cooling (HT4); a major cooling between Early and Late 
Cretaceous (HT5). HT1, HT4 and HT5 all provide too young AHe ages compared to the HT2 and HT3.

313 This preliminary treatment confirms the necessity to set a constraint related to the Lower Cretaceous unconformity in the Tindouf Basin and the TLDB. It is also in line with our consideration regarding the wavelength of cratonic deformation at large wavelength. The inverse modeling was conducted using the Lower Cretaceous unconformity and constraints deduced from the forward modeling. The latter suppose that samples were (1) at temperatures higher than $80^{\circ} \mathrm{C}$ before Early-Middle Jurassic and (2) reheated after the beginning of the Early Cretaceous by $20-40^{\circ} \mathrm{C}$. We let the inverse modeling determine the temperature before the Jurassic, between 0 and $200^{\circ} \mathrm{C}$. Samples with double LTT datings display similar thermal paths (Fig. $6 \mathrm{~d}$-f, $7 \mathrm{~b}$ ). A significant cooling event $\left(\Delta T>40^{\circ} \mathrm{C}\right.$ ) is recorded between the beginning of the Jurassic (220-190 Ma) with minimum temperatures reached in the Early Cretaceous (150-140 Ma) ranging from 55 to $45^{\circ} \mathrm{C}$. Samples underwent a small reheating event (by $20-25^{\circ} \mathrm{C}$ ) until the beginning of the Late Cretaceous (with the exception of a later and stronger reheating for sample TEN1153). Afterwards, samples cooled down to present-day temperature. samples (Fig. 6g-h, 7c). Their thermal path shows an important cooling from Early-Middle Jurassic to Early Cretaceous, from temperatures higher than $100^{\circ} \mathrm{C}$ to $35-40^{\circ} \mathrm{C}$. A reheating phase occurred until the beginning of Late Cretaceous (between $100-80 \mathrm{Ma}$ ), reaching temperatures as high as $65-70^{\circ} \mathrm{C}$. It is followed by a rapid cooling event until early Cenozoic up to $35-40^{\circ} \mathrm{C}$ before a slow cooling until present. 

display more scattering eastwards (Fig. 2). From the LTT data and our thermal modelings one can clearly see that samples stayed in the Partial Retention Zone (PRZ)/Partial Annealing one (PAZ) for a long time. This more or less protracted stay within the PRZ strongly impacts the distribution of AHe ages with respect to the eU (Fig. 5). For example, the curved positive trend of the AHe age-eU plot in figure $5 \mathrm{~b}$ can be explained by low-eU apatites experiencing greater diffusive loss of He (causing younger AHe ages) than high-eU apatites during a short time in the PRZ during Early Cretaceous (1030 Myrs at T>50-60 $\mathrm{C}$; Fig. 7b). This short stay within the PRZ was sufficient to partially reset the low$\mathrm{eU}$ AHe ages in the case of the central Reguibat Shield. We consider for now that the best explanation for anomalous replicates behavior (mostly showing older AHe than what is expected) lies in process of implantation of He from minerals neighbouring apatite in the rock (Spiegel et al., 2009). Up to $>300 \%{ }^{4} \mathrm{He}$ excess has been estimated in most extreme cases by Gautheron et al. (2012). Moreover, low-eU apatites are logically more sensitive to implantation than high-eU apatite and this can dramatically distort the AHe ages (Janowski et al., 2017). With this hypothesis, we propose that implantation and a long residence in the PRZ might explain the larger dispersion of the AHe ages for the eastern Reguibat Shield compared to the central Reguibat Shield. In the case of the western Reguibat Shield, Leprêtre et al. (2015) demonstrated that the apatite crystal chemistry was responsible for an enhanced scattering around a mean AHe age-eU trend (their Fig. 5-7). In addition to $\mathrm{eU}$ and equivalent sphere radius, the influence of apatite composition may also explain some of the scattering seen here given the range of Dpar measurements for the central and eastern Reguibat Shield samples (Tables S1, S2; further discussion in Text S2; Fig. S18).

The NWAC in the Mesozoic Early-Middle Jurassic and the Late Cretaceous. This cooling occurred between Early-Middle Jurassic and Early Cretaceous for western and central Reguibat Shield whereas it happened later, by the end 
of the Early Cretaceous, for the eastern Reguibat Shield. Elevated temperatures during the Early Jurassic can have two origins: (1) a thermal perturbation, linked either to the emplacement of the Central Atlantic Magmatic Province (CAMP, Verati et al., 2007) or to thermal flux increase in connection with rifting; (2) a burial under a sedimentary cover which has been removed only after the break-up. Importantly, the CAMP rocks do not crop out within the Reguibat Shield (Marzoli et al., 1999; Verati et al., 2005). Basal heat flow might have been higher during CAMP magmatism and/or rifting, but would not be anymore anomalous during Cretaceous (Fig. 7b-c). LTT data from borehole samples in the cratonic Anti-Atlas domain, north of the Tindouf Basin (Sehrt, 2014) estimate an average $40^{\circ} \mathrm{C} \cdot \mathrm{km}^{-1}$ palaeogeotherm during the Early-Middle Jurassic/Early Cretaceous without measurable changes afterward. We thus favor the hypothesis of burial of the Reguibat Shield by a Paleozoic sedimentary cover. This cover was removed during Lower-Middle Jurassic/Lower Cretaceous erosion in the western and central Reguibat Shield and fed the clastic deposits of the

372 TLDB during the Early Cretaceous. Similarly, the reheating in the western and central domains 373 between 150 and $100 \mathrm{Ma}$ is interpreted as a re-burial of the samples as no large magmatic anomaly 374 is recorded (Matton \& Jebrak, 2009). The timing and, to a lesser extent, the amplitude of the reburial differs slightly to that proposed in Leprêtre et al. (2014). This can be attributed to the additional AHe datasets used for thermal modeling in the present study. The models differ in the onset and duration of the heating after the Upper Jurassic/Lower Cretaceous transition for models of the central Reguibat (Fig. 7b; Leprêtre et al., 2014, their figure 5). Our present study refines the

379 Leprêtre et al. (2014) models and adds more consistency to them. The heating phase occurred from 380 the end of Early Cretaceous up to the beginning of Late Cretaceous (Fig. 7b) when the major 381 Cenomanian-Turonian flooding is recorded. Plus, the beginning of cooling occurred at the beginning 382 of the Late Cretaceous when the Africa-Europe convergence began. We assert that AHe datasets 383 have helped to better constrain the post-Jurassic evolution of central Reguibat Shield, in comparison 384 with our previous investigations using only AFT analysis. 
Assuming a palaeogeotherm of $30-50^{\circ} \mathrm{C} . \mathrm{km}^{-1}$ during the cooling and reheating and using the duration and amplitude of the thermal changes predicted by our thermal models, we estimated the eroded/deposited rock thicknesses for each event. The ranges of Jurassic/Cretaceous erosion are between $0.8-2.1 \mathrm{~km}$ and 1-1.6 $\mathrm{km}$ from western to eastern Reguibat Shield respectively. The amplitude of re-burial reaches 0.4 to $1.7 \mathrm{~km}$ for the western and central domains, with no re-burial in the eastern Reguibat Shield (Fig. 7a). During the re-burial, the southern TLDB record Albian-Turonian thicknesses that can reach $1 \mathrm{~km}$ (AUXINI, 1969), which are compatible with our estimates. Moreover this cover might have been even thicker given the subsequent Late Cretaceous erosion. In comparison with western and central domains, the eastern Reguibat Shield shows a late cooling event, mostly occurring at the Lower/Upper Cretaceous transition (Fig. 7a). Whether this cooling can be linked to the one recognized in western and central domains is challenging; however, we believe that cooling in the eastern domain represents another phenomenon. There is no significant time lapse between the cooling phase recorded in the western and central Reguibat Shield. If all three domains were cooled by the same process we would then expect the timing of cooling in the eastern Reguibat Shield to be approximately the same as the west and central domains, which is not the case. As there is a significantly delay before the eastern Reguibat Shield cools, this cooling could better be related to the Austrian phase recognized in the Sahara platform (Boudjema, 1987), occurring in Aptian-Albian times. The former N/S Panafrican faults separating the WAC from the Tuareg Shield were reactivated as the northern Tuareg Shield underwent anticlockwise rotation resulting from the opening of the South Atlantic Ocean. The cooling in the eastern Reguibat Shield might stem from the large-scale tectonic reorganization at that time.

Few other studies have dealt with the evolution of cratonic domains on the NWAC. In the Anti-Atlas north of the Tindouf Basin, Ruiz et al. (2011) and Oukassou et al. (2013) demonstrated using LTT data that the northern tip of the craton also underwent uplift and erosion during Jurassic/Early Cretaceous times before a reheating step. Further east (Ahnet-Reggane-Timimoun basins), based on organic matter maturity, AFT and zircon fission-tracks from several wells, Logan \& 
Duddy (1998) proposed a general cooling from Triassic to Early Cretaceous. They also show that the

Variscan erosion is highly reduced in most of the area, in agreement with our results. Eastward, in

413 the central and eastern Sahara, the evolution becomes more diverse. In the Illizi Basin, LTT and organic matter maturity were used by English et al. (2016) to support Cenozoic uplift undergone by the Tuareg Shield. However, their borehole data are not able to resolve the Mesozoic history since they found various likely scenarios for the Jurassic-Cretaceous period, with one scenario involving a small cooling event in the Early Cretaceous. A limited number of LTT studies have been undertaken on the Hoggar basement and they are focused on the Cenozoic exhumation without being able to properly address the Mesozoic history given their poor confined length contents and the abundance of Cenozoic AFT ages (Carpéna, 1988; Cavellec, 2006; Rougier, 2012; Rougier et al., 2013).

\section{Evolution of the conjugate passive margins of the Central Atlantic Ocean}

Several lines of evidence testify to the existence of common processes on each side of the northern Central Atlantic Ocean during Jurassic-Cretaceous times. We present them in the following section.

LTT record on the onshore eastern American passive margin Boettcher \& Milliken, 1994; Roden-Tice et al., 2000; Roden-Tice \& Wintsch, 2002; Grist and Zentilli, 2003; Lorencak et al., 2004; Spotila et al., 2004; Roden-Tice \& Tice, 2005; Taylor \& Fitzgerald, 2011; Roden-Tice et al., 2012). We have collated all of the existing AFT data along eastern North America 
slightly older samples along the Nova Scotia segment in the north. AFT ages become progressively older landward (up to $600 \mathrm{Ma}$, beyond $600-700 \mathrm{~km}$ off the hinge line). The spatial pattern of AFT age is strikingly similar to the NWAC (Fig. 9b-c; after the data of Ghorbal et al., 2008; Saddiqi et al., 2009; Ruiz et al., 2011; Oukassou et al., 2013; this study), with ages being younger (c.a. 100-220 Ma) from the coast to $600 \mathrm{~km}$. AFT-MTL plots are given for both margins (Fig. 9c-d) and show that there is no relationship between the age of rifting and length datasets. This significant observation means that for samples within the $600 / 700-\mathrm{km}$ proximal land strip, the effects of the Lower Jurassic rifting (c.a. $190 \mathrm{Ma}$ ) are barely distinguishable. Both margins seem coherently affected by a more regional event.

\section{Along-strike variations of the passive margin stratigraphical record}

Passive margin sedimentary infills have been studied along both passive margins and can be compared to identify the similarities in their evolution. For this comparison, we use the regional studies of Jansa \& Wiedmann (1982) for Northwest Africa, Grew \& Sheridan (1988) and Miall (2008) for eastern North America. In the following, we present only the stratigraphical records from EarlyMiddle Jurassic to the end of Early Cretaceous.

From north to south along the eastern American passive margin, four segments have been well-documented: Nova Scotia, the Georges Bank, the Baltimore canyon Trough and the Blake plateau (Fig. 10). On the African counterpart, we will present the Essaouira, Tarfaya and Senegal segments.

The Nova Scotia and Georges Bank basins and the Baltimore Canyon Trough are defined by similar stratigraphical formations. The Early Jurassic witnessed the deposition of dolomite and anhydrite layers. These unconformably overlie Triassic formations and gradually became clastic deposits moving laterally and upward in the section. On top of the Early Jurassic rocks, a large carbonate platform aggraded and prograded seaward although a clastic influx still occurred during Middle- Late Jurassic. During Early Cretaceous, carbonate platforms were buried under a thick clastic 
influx of coarse sandstones, which even bypassed the platform edge (Jansa \& Wiedman, 1982; Wade \& MacLean, 1990). By the end of the Early Cretaceous, clastic sedimentation was still ongoing but with a lower influx during the Aptian-Turonian interval when a major transgressive period occurred. South of these three basins, the Blake Plateau has received little attention. Its Middle Jurassic stratigraphy is less known but the Late Jurassic witnessed the formation of a mixed terrigenouscarbonated platform and the build-up of a massive carbonate platform occurred during the Early Cretaceous. The platform was drowned during the Late Cretaceous due to the high-stand sea-level which brought carbonate facies up to the Appalachian range with the deposition of deep-marine marls on the former carbonate platform (Poag \& Valentine, 1988).

On the northwest African passive margin, Jansa \& Wiedmann (1982) described very similar successive facies. In the Essaouira Basin, middle-upper Liassic (Lower Jurassic) records the early postrift transgression with the deposition of dolomites and evaporites, subsequently covered during lower-middle Dogger (Middle Jurassic) by clastics with features characteristic of a marine regression. A stable carbonate platform was built afterwards up to the end of the Late Jurassic. Carbonate deposition was interrupted by some clastic deposition before a last regression in Berriasian times. The Lower Cretaceous formations buried the former platform under kilometer-thick clastics with large prograding deltas until the Aptian. Marine conditions resumed during Aptian with carbonate deposition. From the Cenomanian-Turonian onwards, deeper marine conditions prevailed with outer-shelf to slope type deposit. In the TLDB, the sedimentary record is similar to that in the Essaouira Basin. Finally, in the southern segment of the Senegal Basin, a large carbonate platform formed during the Middle-Late Jurassic to the end of Early Cretaceous. In contrast to the northern segments, deposition of the carbonate platform was not interrupted and small volumes of clastic sediments deposited in the Senegal Basin (Brownfield \& Charpentier, 2003). A carbonate platform even prevailed until the Late Cretaceous in the southern part of the basin. 

similar for the considered period. It becomes increasingly different afterwards in the Late Cretaceous

486 (Jansa \& Wiedmann, 1982) during the convergence climax of Africa and Europe. For the whole margin, the Jurassic witnessed the build-up of an almost continuous carbonate platform, which ended in the beginning of the Early Cretaceous for the north Central Atlantic Ocean whereas this build-up persisted until the Late Cretaceous for the southern segments of the margin. Given the LTT record for both sides of the northern Central Atlantic Ocean described previously, we consider that process which will be discussed in the next section.

\section{Evolution of the Central Atlantic Ocean}

The Central Atlantic Ocean underwent break-up during the Sinemurian ( 190 Ma; Labails et al., 2010). During rifting and the early post-rift stage, a shared stratigraphical record is observed predictably on both sides of the ocean (Jansa \& Wiedmann, 1982; Fig. 10). The spreading rate of the young Atlantic has been estimated by various authors (Cogné \& Humler, 2006; Schettino \& Turco, 498 2009; Labails et al., 2010; Kneller et al., 2012) for the Jurassic period. We present in figure 11 a compilation of these rates. Even if slight differences exist between the different models, all authors agree with a significant increase of this rate during Middle and Late Jurassic before a dramatic decrease in the Early Cretaceous.

One must remember that LTT studies only give the simplest thermal paths between 503 constraint points that can reproduce the data. As such, the Jurassic-Early Cretaceous cooling we 504 obtained could alternate between discrete phases of accelerations and decelerations of the cooling 505 rate from the Early-Middle Jurassic to the Early Cretaceous. Considering the regression and clastic burial of the Jurassic carbonate platforms, we think that an acceleration of the cooling rate would have occurred during the Late Jurassic/Early Cretaceous because of enhanced exhumation. This process can also be suggested for the symmetrical clastic feeding on the conjugate American passive 
margin. Indeed, LTT studies on eastern North America suggest that a significant cooling occurred over large areas during the Middle-Late Late Jurassic to the Early Cretaceous (Fig. 12a-c). This cooling event is partially hidden in the northern Appalachian domain (central transect, the portion close to the Atlantic Ocean in figure 9) where, a strong Early-Late Cretaceous cooling event is attributed to the passage over/close to the Great Meteor hotspot (Taylor \& Fitzgerald, 2011), which could have disrupted the record of the earliest cooling phase (Fig. 12d).

Valid explanations for this Jurassic-Lower Cretaceous uplift must consider the following: (1) the uplift event affected the onshore domains of either side of the conjugate passive margins and over a longer wavelength than it is typically the case usually for other passive margins settings (up to $600 \mathrm{~km}$ landward compared to less than 200-300 km; see Gallagher et al., 1998); (2) in spite of a shared spreading history (Labails et al., 2010), the Central Atlantic Ocean behaved differently at that time and was split into a northern domain, whose margins were uplifted and a southern domain, which experienced the continuous build-up of carbonate platforms (Fig. 10); (3) it must be followed by a significant burial stage during the Early Cretaceous on the western and central Reguibat Shield, with decreasing intensity landward. This burial is not evidenced on the American conjugate margin and thermal stability has been retained after these changes (e.g. Taylor \& Fitzgerald, 2011, their fig. 8; Roden-Tice et al., 2012, their fig. 6-7).

The exhumation recorded on both margins peaked during the post-rift phase, interrupting the classical subsidence post-rift phase, associated with the carbonated platform build-up. It is difficult to argue that early post-rift geomorphological models like scarp retreat or pinned-divide (Gallagher et al., 1998) could be responsible for the distribution of the AFT ages and the evolution of the margin. The NW African passive margin is characterized by a low-elevation profile which does not seem to indicate any erosion retreat and that these rift-related processes usually exert themselves on more restricted geographical scales $(<300 \mathrm{~km}$ inland). Moreover, huge erosion on the coastal plain (and commonly ONLY studied for high-elevation passive margins) is classically explained by 
primary controls such as the geometry of the rifting and the flexural rebound (see Bishop, 2007 and Green et al., 2013 for contrasted reviews). In our studied case, the asymmetrical mechanism of rifting and the different crust-lithosphere geometries of the conjugate margins do not argue for both margins to behave in such a similar way (Maillard et al., 2006; Labails et al., 2009). We also discard an explanation involving regional compression to account for these results in the western and central domains of the Reguibat Shield and the American conjugate passive margin. Bertotti \& Gouiza (2012) proposed this tectonic hypothesis for northern Morocco over the Late Jurassic/Early Cretaceous. However, their arguments are based on limited structural evidence that is focused on their study area. These features could also be explained as being halokinesis features (e.g. Saura et al., 2014). Additionally, pre-Late Cretaceous compressional features have never been described on the Moroccan-Mauritanian passive margin during this period, before the onset of Africa-Europe convergence (Rosenbaum et al., 2002).

We propose a hypothesis that involves mantle-related dynamic processes to account for the symmetrical uplifts on both sides of the northern Central Atlantic. The geographical extension of the eroded area points to a large-scale process, which could be attributed to ascending hot mantle material below the northern Central Atlantic Ocean. During Late Jurassic-Early Cretaceous, magmatism is absent across both margins (see the review by Matton \& Jebrak, 2009). Scarce basic magmatic outcrops exist in northern Morocco (Frizon de Lamotte et al., 2008) and in North America (McHone \& Butler, 1984) from this period. Their absence over most of the NWAC can be explained by lack of structural pathways that allow the magma to pierce through the cratonic domain of the Reguibat Shield. Spreading of a large shallow plume head below the northern Central Atlantic Ocean lithosphere is thus not discarded but it would have to have impacted the base of the lithosphere at a lower temperature than typical plume heads or at great sub-lithospheric depths, which therefore prevent the development of a large volume of magmatism. Such a large hot mantle would have had wide reaching effects at this time and would have impacted Northwest Africa and eastern North America (this study), and even Iberia (e.g. Grobe et al., 2014). The timing of the mantle plume is 
concomitant with the second phase of the rifting between Iberia and Newfoundland (Tucholke et al., 2007). The delay between the increase in Middle-Upper Jurassic spreading rates in the Central Atlantic Ocean and the Lower Cretaceous clastic influx to the margins (Fig. 10,11) is consistent with the lag time for the thermal mantle anomaly to reach the surrounding continents and create uplift. On a smaller scale, such a mechanism, as proposed here, could be similar to the "hot pulses" linked to the Icelandic plume that spread out radially beneath the lithosphere as proposed by Hartley et al. (2011) to explain various Cenozoic uplifts in this area of North Atlantic Ocean. In our case, the more important Mesozoic uplift-burial cycle affecting Northwest Africa is interpreted as being a result of NW Africa residing closest to an underlying mantle thermal anomaly compared to the conjugate margin. This has resulted in a stronger dynamic uplift effect which triggered episodes of erosion and burial that are able to be recorded by LTT methods. After the "dynamic pulse" that pushed upward the NWAC, its decrease led consequently to an opposite trend in the western and central Reguibat domains that allowed the re-burial of the margin in the extent revealed by our study, fading eastward within the craton. A potential contribution of eroding material from the eastern Reguibat Shield to this burial may be possible. Nevertheless, we are not able to properly evaluate this contribution since no sedimentary remnants are preserved within the Reguibat Shield nowadays.

\section{Conclusion}

This LTT study evidenced a Lower-Middle Jurassic to Upper Cretaceous kilometric erosion event that occurred in the previously presumed to be stable Northwest Africa. This result has major consequences for the Reguibat Shield and Northwest Africa and is probably related to the Central Atlantic expansion.

Along a roughly E-W $\sim 1300 \mathrm{~km}$ transect of the Reguibat Shield, we show that kilometer-scale erosion occurred from Early-Middle Jurassic to the Early Cretaceous for the western and central 
domains. The eastern domain of the Reguibat Shield also underwent an erosional event but it occurred later in the Early Cretaceous. The erosion of central and western domains was followed by subsequent reheating/burial with decreasing intensity landward, before final cooling from Late Cretaceous to present-day in western and central Reguibat Shield domains. For eastern Reguibat Shield domain, the brief pulse of erosion can be identified at the Lower-Upper Cretaceous transition and we may tentatively relate it to the Austrian unconformity.

These results have important implications when placed in the wider context of the geodynamic setting of the Central Atlantic Ocean evolution. We demonstrate a similar pattern of erosion occurring on the conjugate passive margin of eastern North America during the same period. This long wavelength uplift event only affected the northern part of the continents surroundings the young ocean and has an extent compatible with transient large scale mantle processes. A lowtemperature or deeply located sub-lithospheric mantle plume head responsible for this uplift is concomitant with the second and last phase of rifting in the southern North Atlantic Ocean and could have played a significant role in triggering its oceanic opening.

\section{Acknowledgements}

We thank Eric Douville for accessing the ICP-MS (LSCE, Gif-sur-Yvette) and Louise Bordier for the U-Th measurements. This work has been supported by the Académie Hassan II des Sciences, Casablanca, Morocco. We acknowledged P.F. Green and an anonymous reviewer for the remarks and comments that greatly helped clarifying and precising numerous points in the present manuscript. 
Armitage, J.J., Jaupart, C., Fourel, L. \& Allen, P.A. 2013. The instability of continental passive margins 608 and its effect on continental topography and heat flow. Journal of Geophysical Research: Solid Earth, 118, 1817-1836, doi: 10.1002/jgrb.50097. AUXINI 1969. Correlación estratigrafica de los sondeos perforados en el Sahara Español. Boletín Geológico y Minero, 83, 235-251. track annealing in apatite. Chemical Geology, 198, 107-137, doi: 10.1016/S0009-2541(02)00424-2. Bea, F., Montero, P., Haissen, F. \& El Archi, A. 2013. 2.46 Ga kalsilite and nepheline syenites from the Awsard pluton, Reguibat Rise of the West African Craton, Morocco. Generation of extremely K-rich magmas at the Archean-Proterozoic transition, Precambrian Research, 224, 242-254, doi: 10.1016/j.precamres.2012.09.024. Bertotti, G. and Gouiza, M. 2012. Post-rift vertical movements and horizontal deformations in the eastern margin of the Central Atlantic: middle Jurassic to Early Cretaceous evolution of Morocco. International Journal of Earth Sciences, 101, 2151-65, doi: 10.1007/s00531-012-0773-4. sequences of the West African Craton. In: Dallmeyer, R.D. \& Lécorché, J.P. (eds) The West African Orogens and Circum-Atlantic Correlatives, Springer-Verlag, IGCP-Project, 223, 65-82. 655- 663. 
Boote, D.R.D, Clark-Lowes, D.D. \& Traut, M.W. 1998. Paleozoic petroleum systems of North Africa. In: MacGregor, D.S., Moody, R.T.J. \& Clark-Lowes, D.D. (eds) Petroleum Geology of North Africa. Geological Society, London, Special Publications, 132). , 7-68, doi: 10.1144/GSL.SP.1998.132.01.02

Boudjema, A. 1987. Evolution structurale du bassin pétrolier "triasique" du Sahara nord oriental (Algerie). PhD thesis, Université Paris Sud XI, France.

Brown, R.W., Beucher, R., Roper, S., Persano, C., Stuart, F. \& Fitzgerald, P. 2013. Natural age dispersion arising from the analysis of broken crystals. Part I: Theoretical basis and implications for the apatite (U-Th)/He thermochronometer. Geochimica et Cosmochimica Acta, 122, 478-497, doi: 10.1016/j.gca.2013.05.041.

Brownfield, M.E. and Charpentier, R.R., 2003. Assessment of the undiscovered oil and gas of the Senegal Province, Mauritania, Senegal, The Gambia, and Guinea-Bissau, Northwest Africa, United States Geological Survey Bulletin, 25p.

Burkhard, M., Caritg, S., Helg, U., Robert-Charrue, C. \& Soulaimani, A. 2006. Tectonics of the AntiAtlas of Morocco. Comptes Rendus Géoscience, 338 (1-2), 11-24.

Busson, G., 1972. Principes, méthodes et résultats d'une étude stratigraphique du mésozoïque saharien. Mémoires du Muséum d'Histoire Naturelle, Nouvelle Series, Série C, Sciences de la Terre, 26, 441p.

Burov, E.B. 2011. Rheology and strength of the lithosphere. Marine and Petroleum Geology, 28, 1402-1443, doi:10.1016/j.marpetgeo.2011.05.008.

Carlson, W.D., Donelick, R.A. \& Ketcham, R.A. 1999. Variability of apatite fission-track annealing kinetics: I. Experimental results. American Mineralogist, 84, 1213-1223, doi: 10.2138/am-1999-0901.

Carpéna, J., Kienast, J., Ouzegane, K., \& Jehanno, C. 1988. Evidence of the contrasted fission-track clock behavior of the apatites from In Ouzzal carbonatites (northwest Hoggar): The low-temperature 
650

651

652

653

654

655

656

657

658

659

660

661

662

663

664

665

666

667

668

669

670

thermal history of an Archean basement. Geological Society of America Bulletin, 100, 1237-1243, doi : 10.1130/0016-7606(1988)100.

Cavellec, S., 2006. Evolution diagénétique du basin de Tim Mersoï et conséquences pour la génèse des minéralisations uranifères dans les formations carbonifères du Guezouman et du Tarat (district ArlitAkokan, Niger). PhD thesis, Université Paris Sud XI.

Cogné, J.-P. and Humler, E., 2006. Trends and rythms in global seafloor generation rate. Geochemistry, Geophysics, Geosystems, 7(3), doi:10.1029/2005GC001148.

Cogné, N., Gallagher, K., Cobbold, P.R., Riccomini, C. \& Gautheron, C. 2012. Post-breakup tectonics in southeast Brazil from thermochronological data and combined inverse-forward thermal history modeling. Journal of Geophysical Research, 117, B11413, doi:10.1029/2012JB009340.

Crowley, K.D. 1991. Thermal History of Michigan Basin and Southern Canadian Shield from apatite fission track analysis. Journal of Geophysical Research: Solid Earth, 96(B1), 697-711, doi: 10.1029/90JB02174.

Deynoux, M. 1980. Les formations glaciaires du Précambrien terminal et de la fin de l'Ordovicien en Afrique de l'Ouest. Deux exemples de glaciation d'inlandsis sur une plateforme stable. Travaux du Laboratoire de Sciences de la Terre, St Jérôme, Marseille.

Djimbi, D.M., Gautheron, C., Roques, J., Tassan-Got, L., Gerin, C. \& Simoni, E., 2015. Impact of apatite chemical composition on (U-Th)/He thermochronometry: An atomistic point of view. Geochimica et Cosmochimica Acta, 167, 162-176, doi:10.1016/j.gca.2015.06.017.

Dodson, M. H. (1973), Closure temperature in cooling geochronological and petrological systems, Contributions to Mineralogy and Petrology, 40, 259-274, doi: 10.1007/BF00373790. 
671 English, K., Redfern, J., Bertotti, G., English, J.M. \& Cherif, R.Y., 2016. Intraplate uplift: new 672 constraints on the Hoggar dome from the Illizi basin (Algeria). Basin Research, doi: $673 \quad 10.1111 /$ bre.12182.

674 Fabre, J., Arnaud-Vanneau, A., Belhadj, Z. \& Monod, T. 1996. Evolution des terrains méso675 cénozoïques d'une marge à l'autre du craton ouest africain, entre le Tanezrouft (Algérie) et l'Adrar de 676 Mauritanie. In : Bitam, L. \& Fabre, J. (eds) Géodynamique du craton ouest africain central et oriental : 677 héritage et évolution post-panafricains. Service géologique de l'Algérie, Boumerdès, Mémoires du 678 Service Géologique de l’Algérie, 8, 187-229.

679 Fabre, J. 2005. Géologie du Sahara occidental et central. Musée Royal de l'Afrique Central, Tervuren, 680 African Geoscience Collection, 108.

681 Flowers, R.M., Ketcham, R.A., Shuster, D. \& Farley, K.A. 2009. Apatite (U-Th)/He thermochronology 682 using a radiation damage accumulation and annealing model. Geochimica et Cosmochimica Acta, 73, 683 2347-2365, doi:10.1016/j.gca.2009.01.015.

684 Flowers, R.M. \& Kelley, S.A. 2011. Interpreting data dispersion and "inverted" dates in apatite (U685 Th)/He and fission-track datasets: An example from the US Midcontinent. Geochimica et 686 Cosmochimica Acta, 75, 5169-5186, doi:10.1016/j.gca.2011.06.016.

687 Frizon de Lamotte, D., Zizi, M., Missenard, Y., Hafid, M., El Azzouzi, M., Maury, R.C., Charrière, A., 688 Taki, Z., Benammi, M. \& Michard, A., 2008. The Atlas system. In: Michard, A., Chalouan, A. and 689 Saddiqi, O. (eds) Continental Evolution: The Geology of Morocco. Structure, Stratigraphy, and 690 Tectonics of the Africa-Atlantic-Mediterranean Triple Junction, Springer Verlag, Lecture Notes in Earth 691 Sciences, 116, 133-202 doi: 10.1007/978-3-540-77076-3_4.

692 Frizon de Lamotte, D., Tavakoli-Shirazi, S., Leturmy, P., Averbuch, O., Mouchot, N., Raulin, C., 693 Leparmentier, F., Blanpied, C. \& Ringenbach, J.-C. 2013. Evidence for Late Devonian vertical 
694

695

696

697

698

699

700

701

702

703

704

705

706

707

708

709

710

711

712

713

714

715

movements and extensional deformation in Northern Africa and Arabia - Integration in the geodynamics of the Devonian world. Tectonics, 32( 2), 107-122, doi: 10.1002/tect.20007

Furon, R. 1956. Sahara, Afrique occidentale française et portugaise. Lexique stratigraphique international. Editions du CNRS, Paris, IV (2), Afrique.

Galbraith, R. F. \& Laslett, G.M. 1993. Statistical models for mixed fission track ages. Nuclear tracks and radiation measurements, 21, 459-480, doi:10.1016/1359-0189(93)90185-C.

Gallagher, K., Brown, R.W., \& Johnson, C. 1998. Fission track analysis and its applications to geological problems. Annual Review of Earth and Planetary Sciences, 26 (5), 9-72, doi: 10.1146/annurev.earth.26.1.519.

Gallagher, K. 2012. Transdimensional inverse thermal history modeling for quantitative thermochronology. Journal of Geophysical Research, 117, B02408, doi:10.1029/2011JB008825.

Gautheron, C., Tassan-got, L., Barbarand, J. \& Pagel, M. 2009. Effect of alpha-damage annealing on apatite (U-Th)/He thermochronology. Chemical Geology, 266, 166-179, doi:10.1016/j.chemgeo.2009.06.001.

Gautheron, C., Tassan-got, L., Ketcham, R.A. \& Dobson, K.J. 2012. Accounting for long alpha-particle stopping distances in (U-Th-Sm)/He geochronology: 3D modeling of diffusion, zoning, implantation, and abrasion. Geochimica et Cosmochimica Acta, 96, 44-56, doi:10.1016/j.gca.2012.08.016.

Gautheron, C., Barbarand, J., Ketcham, R.A., Tassan-Got, L., van der Beek, P., Pagel, M., Pinna-Jamme, R., Couffignal, F. \& Fialin, M., 2013. Chemical influence on $\alpha$-recoil damage annealing in apatite: Implications for (U-Th)/He dating. Chemical Geology, 351, 257-267, doi: 10.1016/j.chemgeo.2013.05.027.

Gevin, P. 1960. Etudes et reconnaissances géologiques sur l'axe cristallin Yetti-Eglab et ses bordures sédimentaires (1ere partie: bordures sédimentaires). Service de la carte géologique de l'Algérie 23. 
Ghorbal, B., Bertotti, G., Foeken, J. \& Andriessen, P. 2008. Unexpected Jurassic to Neogene vertical movements in "stable" parts of NW Africa revealed by low temperature geochronology. Terra Nova, 20 (5), 355-363, doi:10.1111/j.1365-3121.2008.00828.x.

Gleadow, A.J.W. \& Duddy, I.R. 1981. A natural long-term track annealing experiment for apatite. Nuclear Tracks, 5, 169-174, doi:10.1016/0191-278X(81)90039-1.

Green, P.F. \& Duddy, I.R. 2010. Synchronous exhumation events around the Arctic including examples from Barents Sea and Alaska North Slope. In: Vining, B.A. \& Pickering, S.C. (eds) Petroleum Geology: From Mature Basins to Now Frontiers - Proceedings of the $7^{\text {th }}$ Petroleum Geology Conference, Geologocal Society, London, Petroleum Geology Conference series, 7, 633-644, doi: $10.1144 / 0070633$

Green, P.F., Lidmar-Bergström, K., Japsen, P., Bonow, J.M. \& Chalmers, J.A. 2013. Stratigraphic landscape analysis, thermochronology and the episodic development of elevated, passive continental margins. Geological Survey of Denmark and Greenland Bulletin, 30, 150p.

Grow, J.A. \& Sheridan, R.E., 1988. U.S. Atlantic continental margin: a typical Atlantic-type or passive continental margin. In: Sheridan, R.E. \& Grow, J.A. (eds) The Atlantic Continental Margin, Geological Society of America, Geology of North America, Boulder, Colorado, 1-2, 1-7.

Grist, A.M. \& Zentilli, M. 2003. Post-Paleocene cooling in the southern Canadian Atlantic region: evidence from apatite fission track models. Canadian Journal of Earth Sciences, 40 (9), 1279-1297, doi: 10.1139/e03-045.

Grobe, R.W., Alvarez-Marrón, J., Glasmacher, U.A. \& Stuart, F.M. 2014. Mesozoic exhumation history and paleolandscape of the Iberian Massif in eastern Galicia from apatite fission-track and (U+Th)/He data. International Journal of Earth Sciences, 103 (2), 539-561, doi: 10.1007/s00531-013-0976-3. 
Haddoum, H., Guiraud, R. \& Moussine-Pouchkine, A. 2001. Hercynian compressional deformations of the Ahnet-Mouydir Basin, Algerian Saharan Platform: far-field stress effects of the Late Paleozoic orogeny. Terra Nova, 13, 220-226, doi: 10.1046/j.1365-3121.2001.00344.x.

Hartley, R.A., Roberts, G.G., White, N. \& Richardson, C. 2011. Transient convective uplift of an ancient buried landscape. Nature Geoscience, 4, 562-565, doi: 10.1038/NGEO1191

Holford, S.P., Green, P.F., Duddy, I.R., Turner, J.P., Hillis, R.R. \&Stoker, M.S. 2009. Regional intraplate exhumation episodes related to plate-boundary deformation. Geologial Society of America Bulletin, 121 (11-12), 1611-1628, doi:10.1130/B26481.1.

Huismans, R. \& Beaumont, C. 2011. Depth-dependent extension, two-stage breakup and cratonic underplating at rifted margins. Nature, 473, 74-79, doi:10.1038/nature09988.

Hurford, A. J. 1990. Standardization of fission track dating calibration: recommendation by the Fission Track Working Group of the I.U.G.S. Subcommission on Geochronology. Chemical Geology: Isotope Geoscience section, 80 (2), 171-178, doi:10.1016/0168-9622(90)90025-8.

Hurford, A.J., and Green, P.F. \& Green, P.F. 1983. The zeta age calibration of fission-track dating, Chemical Geology, 41, 285-317, doi:10.1016/S0009-2541(83)80026-6.

Janowski, M., Loget, N., Gautheron, C., Barbarand, J., Bellahsen, N., Van den Driessche, J., Babault, J. \& Meyer, B. 2017. Neogene exhumation and relief evolution in the eastern Betics (SE Spain): insights from the Sierra de Gador. Terra Nova in press, doi:10.1111/ter.12252..

Jansa, L.F. \& Wiedmann, J. 1982. Mesozoic-Cenozoic Development of the Eastern North American and Northwest African continental margins: a comparison. In: von Rad, U. et al. (eds) Geology of the Northwest African Continental Margin, Springer-Verlag, Berlin Heidelberg, 215-269. 
Japsen, P., Bonow, J.M., Green, P.F., Chalmers, J.A. \& Lidmar-Bergström, K. 2006. Elevated, passive continental margins: long-term highs or Neogene uplifts? New evidence from West Greenland. Earth and Planetary Science Letters, 248, 315-324, doi:10.1016/j.epsl.2006.05.036.

Japsen, P., Chalmers, J.A., Green, P.F. \& Bonow, J.M., 2012. Elevated, passive continental margins: Not rift shoulders, but expressions of episodic, post-rift burial and exhumation. Global and Planetary Change, 90-91, 73-86, doi: 10.1016/j.gloplacha.2011.05.004.

Ketcham, R.A. 2005. Forward and Inverse modeling of Low-temperature Thermochronometry data. Reviews in Mineralogy \& Geochemistry, 58 (1), 275-314, doi: 10.2138/rmg.2005.58.11.

Ketcham, R. A., Carter, A., Donelick, R. A., Barbarand, J. \& Hurford, A. J. 2007. Improved modeling of fission-track annealing in apatite. American Mineralogist, 92, 799-810, doi: 10.2138/am.2007.2281.

Ketcham, R. A., Gautheron, C. \& Tassan-Got, L. 2011. Accounting for long alpha-particle stopping distances in (U-Th-Sm)/He geochronology: refinement of the baseline case. Geochimica et Cosmochimica Acta, 75, 7779-7791, doi:10.1016/j.gca.2011.10.011.

Klingelhoefer, F., Labails, C., Cosquer, E., Rouzo, S., Géli, L., Aslanian, D., Olivet, J.L., Sahabi, M., Nouzé, H. \& Unternehr, P., 2009. Deep crustal structure of the SWMorrocan margin from wideangle and reflection seismic data (The DAKHLA experiment). Tectonophysics, 468, 63-82, doi:10.1016/j.tecto.2008.07.022.

Kneller, E.A., Johnson, C.A., Karner, G.D., Einhorn, J. \& Queffelec, T.A. 2012. Inverse methods for modeling non-rigid plate kinematics: Application to Mesozoic plate reconstructions of the Central Atlantic. Computers \& Geosciences, 49, 217-230, doi:10.1016/j.cageo.2012.06.019.

Kraml, M., Pik, R., Rahn, M., Selbekk, R., Carignan, J. \& Keller, J. 2006. A new multi-mineral age reference material for ${ }^{40} \mathrm{Ar} /{ }^{39} \mathrm{Ar}$, (U-Th)/He and fission track dating methods: the Limberg t3 Tuff. Geostandards and Geoanalytical Research, 30, 73-86, doi: 10.1111/j.1751-908X.2006.tb00914.x. 
783

784

Labails, C., Olivet, J.L. \& The Dakhla study group, 2009. Crustal structure of the SW Moroccan margin from wide-angle and reflection seismic data (the Dakhla experiment). Part B - The tectonic heritage. Tectonophysics, 468, 83-97, doi:10.1016/j.tecto.2008.08.028.

Labails, C., Olivet, J.L., Aslanian, D. \& Roest, W.R. 2010. An alternative early opening scenario for the Central Atlantic Ocean. Earth and Planetary Science Letters, 297, 355-368, doi:10.1016/j.epsl.2010.06.024.

Lahondère, D., Thiéblemont, D., Goujou, J.C., Roger, J., Moussine-Pouchkine, A., Le Métour, J., Cocherie, A. \& Guerrot, C. 2003. Notice explicative des cartes géologiques et gîtologiques à 1:200 000 et 1:500 000 du Nord de la Mauritanie, Direction des Mines et de la Géologie, Ministère des Mines et de l'Industrie, Nouakchott, Mauritanie, 1.

Lefranc, J.P. \& Guiraud, R. 1990. The Continental Intercalaire of northwestern Sahara and its equivalents in the neighbouring regions. Journal of African Earth Science, 10 (1-2), 27-77, doi:10.1016/0899-5362(90)90047-I.

Legrand-Blain, M. \& Perret-Mirouse, M.F. 2000. Brachiopodes et Conodontes carbonifères du bassin de Taoudeni (Mali, Afrique de l'Ouest) : biostratigraphie et paléogéographie. Travaux de I'Institut Scientifique de Rabat, série géologie et géographie physique, 20, 92-107.

Leprêtre, R., Barbarand, J., Missenard, Y., Leparmentier, F. and Frizon de Lamotte, D. 2014. Vertical movements along the northern border of the West African Craton : the Reguibat Shield and adjacent basins. Geological Magazine, 151 (5), 885-898, doi:10.1017/S0016756813000939.

Leprêtre, R., Barbarand, J., Missenard, Y., Gautheron, C., Saddiqi, O. \& Pinna-Jamme, R. 2015. Postrift history of the eastern central Atlantic passive margin: Insights from the Saharan region of South Morocco. Journal of Geophysical Research: Solid Earth, 120(6), 4645-4666, doi: $10.1002 / 2014 J B 011549$ 
Logan, P. \& Duddy, I.R. 1998. An investigation of the thermal history of the Ahnet and Reggane Basins, Central Algeria, and the consequences for hydrocarbon generation and accumulation. In: MacGregor, D.S., Moody, R.T.J. \& Clark-Lowes, D.D. (eds.). Petroleum Geology of North Africa, Geological Society, London, Special Publications, 132, 131- 155, doi: 10.1144/GSL.SP.1998.132.01.07.

Marzoli, A., Renne, P.R., Piccirillo, E.M., Ernesto, M., Bellieni, G. \& De Min, A. 1999. Extensive 200 million-year-old continental flood basalts of the Central Atlantic Magmatic Province. Science, 284, 616-618, doi:10.1126/science.284.5414.616

Lorencak, M., Kohn, B.P., Osadetz, K.G. \& Gleadow, A.J.W., 2004. Combined apatite fission track and (U-Th)/He thermochronometry in a slowly cooled terrane: results from a 3440-m-deep drill hole in the southern Canadian Shield. Earth and Planetary Science Letters, 227, 87-104, doi:10.1016/j.epsl.2004.08.015.

Maillard, A., Malod, J., Thiébot, E., Klingelhoefer, F. \& Réhault, J.-P. 2006. Imaging a lithospheric detachment at the continent-ocean crustal transition off Morocco. Earth and Planetary Science Letters, 241, 686-698, doi:10.1016/j.epsl.2005.11.013.

Martinis, B. \& Visintin, V. 1966. Données géologiques sur le bassin sédimentaire côtier de Tarfaya. In: Reyre, D. (ed) Sedimentary Basins of the African Coasts, Part 1: Atlantic Coast, Association des Services Géologiques Africains, Paris, 13-26.

Matton, G. \& Jebrak, M. 2009. The Cretaceous Peri-Atlantic Alkaline Pulse (PAAP): deep mantle plume origin or shallow lithospheric break-up? Tectonophysics, 469, 1-12, doi:10.1016/j.tecto.2009.01.001.

McDowell, F. W.,McIntosh, W. C. \& Farley, K. A. 2005. A precise 40Ar-39Ar reference age for the Durango apatite (U-Th)/He and fission-track dating standard. Chemical Geology, 214, 249-63, doi:10.1016/j.chemgeo.2004.10.002. 
McHone, J.G. \& Butler, J.R. 1984. Mesozoic igneous provinces of New England and the opening of the North Atlantic Ocean. Geological Society of America Bulletin, 95 (7), 757-765, doi: 10.1130/00167606(1984)9.

Miall, A.D., Balkwill, H.R. \& McCracken, J., 2008. The Atlantic Margin Basins of North America. In: Miall, A.D. (ed) The Sedimentary Basins of the United States and Canada, Sedimentary Basins of the World, Elsevier, Amsterdam, Boston, Heidelberg, 5, 473-504, , doi: 10.1016/S1874- 5997(08)00014-2.

Michard, A., Soulaimani, A., Hoepffner, C., Ouanaimi, H., Baidder, L., Rjimati, E.C. \& Saddiqi, O. 2010. The South-Western Branch of the Variscan Belt: Evidence from Morocco. Tectonophysics, 492, 1-24, doi:10.1016/j.tecto.2010.05.021.

Murray, K.E., Orme, D.A. \& Reiners, P.W. 2014. Effects of U-Th-rich grain boundary phases on apatite helium ages. Chemical Geology, 390, 135-151, doi:10.1016/j.chemgeo.2014.09.023.

Oukassou, M., Saddiqi, O., Barbarand, J., Sebti, S., Baidder, L. \& Michard, A. 2013. Post-Variscan exhumation of the Central Anti-Atlas (Morocco) constrained by zircon and apatite fission-track thermochronology. Terra Nova, 25 (2), 151-159, doi: 10.1111/ter.12019.

Peucat, J.J., Capdevila, R., Drareni, A., Mahdjoub, Y. \& Kahoui, M. 2005. The Eglab massif in the West African Craton (Algeria), an original segment of the Eburnean orogenic belt: petrology, geochemistry and geochronology. Precambrian Research, 136, 309-352, doi:10.1016/j.precamres.2004.12.002.

Poag, C.W. \& Valentine, P.C. 1988. Mesozoic and Cenozoic stratigraphy of the United States Atlantic continental shelf and slope. In: Sheridan, R.E. \& Grow, J.A. (eds) The geology of North America: the Atlantic continental margin, Geological Society of America, Boulder, Colorado, 1-2, 67-85.

Poag, C.W. \& Schlee, J. S. 1984. Depositional sequences and stratigraphic gaps on submerged United States Atlantic margin. In: Schlee, J.S. (ed.) Interregional Unconformities and Hydrocarbon Accumulation, American Association of Petroleum Geologists, Memoir, 36, 165-182. 
Potrel, A., Peucat, J.J. \& Fanning, C.M. 1998. Archean crustal evolution of the West African Craton: example of the Amsaga Area (Reguibat Rise). U-Pb and Sm-Nd evidence for crustal growth and recycling. Precambrian Research, 90 (3-4), 107-117, doi:10.1016/S0301-9268(98)00044-8.

Ranke, U., von Rad, U. \& Wissmann, G. 1982. Stratigraphy, facies and tectonic development of the on- and off-shore Aaiun-Tarfaya basin-A review. In: von Rad, U., Hinz, K., Sarnthein, M. \& Seibold, E. (eds) Geology of the Northwestern African Continental Margin, Springer-Verlag, New York, Berlin, Heidelberg, 86-105, doi: 10.1007/978-3-642-68409-8_6.

Ratschiller, L.K. 1968. Lithostratigraphy of the Northern Sahara. Museo tridentino di scienze naturali, Trento, Italy.

Roden-Tice, M.K., Tice, S.J. and Schofield, I.S., 2000. Evidence for Differential Unroofing in the Adirondack Mountains, New York State, determined by apatite fission-track thermochronology. Journal of Geology, 108, 155-169, doi: 10.1086/314395.

Roden-Tice, M.K. \& Wintsch, R.P., 2002. Early Cretaceous Normal Faulting in Southern New England: Evidence from Apatite and Zircon Fission-Track Ages. Journal of Geology, 110 (2), 159-178, doi: $10.1086 / 338281$

Roden-Tice, M.K. \& Tice, S.J., 2005. Regional-Scale Mid-Jurassic to Late Cretaceous Unroofing from the Adirondack Mountains through Central New England Based on Apatite Fission-Track and (U-Th)/He Thermochronology. Journal of Geology, 113 (5), 535-552, doi: 10.1086/431908.

Roden-Tice, M.K., Dykstra Eusden, J. \& Wintsch, R.P. 2012. Apatite fission-track evidence for the Cretaceous development of kilometer-scale relief and steady-state Tertiary topography in New England. Geomorphology, 141-142, 114-120, doi:10.1016/j.geomorph.2011.12.029.

Rosenbaum, G., Lister, G.S. \& Duboz, C., 2002. Relative motions of Africa, Iberia and Europe during Alpine orogeny. Tectonophysics, 359, 117-129, doi:10.1016/S0040-1951(02)00442-0. 
Rougier, S. 2012. Interactions Lithosphère-Asténosphère et mouvements verticaux : Le cas du massif du Hoggar. PhD thesis, Université Paris Sud XI, France.

Rougier, S., Missenard, Y., Gautheron, C., Barbarand, J., Zeyen, H., Pinna, R., Liégeois, J.P., Bonin, B., Ouabadi, A., Derder, M. E.M. \& Frizon de Lamotte, D. 2013. Eocene exhumation of the Tuareg Shield (Sahara Desert, Africa). Geology, 41 (5), 615-618, doi: 10.1130/G33731.1.

Ruiz, G. M. H., Sebti, S., Negro, F., Saddiqi, O., Frizon de Lamotte, D., Stockli, D., Foeken, J., Stuart, F., Barbarand, J.\& Schaer, J.-P. 2011. From central Atlantic continental rift to Neogene uplift - western Anti-Atlas (Morocco). Terra Nova, 23, 35-41, doi: 10.1111/j.1365-3121.2010.00980.x.

Saddiqi, O., El Haimer, F.-Z., Michard, A., Barbarand, J., Ruiz, G. M. H., Mansour, E. M., Leturmy, P. \& Frizon de Lamotte, D. 2009. Apatite fission-track analyses on basement granites from south-western Meseta, Morocco: paleogeographic implications and interpretation of AFT age discrepancies. Tectonophysics, 475, 29-37, doi:10.1016/j.tecto.2009.01.007.

Schettino, A. \& Turco, E., 2009. Breakup of Pangaea and plate kinematics of the central Atlantic and Atlas regions. Geophysical Journal International, 178, 1078-1097, doi: 10.1111/j.1365246X.2009.04186.x.

Schofield, D.I., Horstwood, M.S.A., Pitfield, P.E.J., Gillespie, M., Darbyshire, F., O'Connor, E.A. \& Abdouloye, T.B. 2012. U-Pb dating and $\mathrm{Sm}-\mathrm{Nd}$ isotopic analysis of granitic rocks from the Tiris Complex: New constaints on key events in the evolution of the Reguibat Shield, Mauritania. Precambrian Research, 204-205, 1-11, doi:10.1016/j.precamres.2011.12.008.

Sebti, S., Saddiqi, O., El Haimer, F.Z., Michard, A., Ruiz, G., Bousquet, R., Baidder, L. \& Frizon de Lamotte, D. 2009. Vertical movements at the fringe of the West African Craton: First zircon fission track datings from the Anti-Atlas Precambrian basement, Morocco. Comptes Rendus Géoscience, 341, 71-77, doi:10.1016/j.crte.2008.11.006. 
Sehrt, M. 2014. Variscan to Neogene long-term landscape evolution at the Moroccan passive continental margin (Tarfaya Basin and western Anti-Atlas). PhD thesis, Ruprecht-Karls-Universität, Heidelberg, Germany.

Sheridan, R.E. \& Grow, J.A. 1988. The Atlantic continental margin, Geological Society of America, Boulder, Colorado, USA.

Shuster, D.L., Flowers, R.M. and Farley, K.A., 2006. The influence of natural radiation damage on helium diffusion kinetics in apatite. Earth and Planetary Science Letters, 249, 148-161, doi:10.1016/j.epsl.2006.07.028.

Shuster, D.L. \& Farley, K.A., 2009. The influence of artificial radiation damage and thermal annealing on helium diffusion kinetics in apatite. Geochimica et Cosmochimica Acta, 73, 183-196, doi:10.1016/j.gca.2008.10.013.

Spiegel C., Kohn B., Belton D., Bernerc Z., Gleadow A. (2009) Apatite (U-Th-Sm)/He thermochronology of rapidly cooled samples: The effect of He implantation. Earth and Planetary Science Letters 285, 1-2, 105-114

Spotila, J.A., Bank, G.C., Reiners, P.W., Naeser, C.W., Naeser, N.D. \& Henika, B.S., 2004. Origin of the Blue Ridge escarpment along the passive margin of Eastern North America. Basin Research, 16, 4163, doi: 10.1046/j.1365-2117.2003.00219.x.

Stampfli, G.M. \& Borel, G.D. 2004. The TRANSMED Transects in Space and Time: Constraints on the Paleotectonic Evolution of the Mediterranean Domain. In: Cavazza, W., Roure, F., Spakman, W., Stampfli, G.M. \& Ziegler, P.A. (eds) The TRANSMED Atlas. The Mediterranean Region from Crust to Mantle, Springer, Berlin, Heidelberg, 53-80, doi: 10.1007/978-3-642-18919-7_3.

Tavakoli-Shirazi, S., Frizon de Lamotte, D., Wrobel-Daveau, J.C. \& Ringenbach, J.C. 2012. Pre-Permian uplift and diffuse extensional deformation in the High Zagros Belt (Iran): integration in the 
921 geodynamic evolution of the Arabian plate. Arabian Journal of Geosciences, 6 (7), 2329-2342, doi:

$922 \quad 10.1007 / \mathrm{s} 12517-012-0542-5$.

923 Taylor, J.P. \& Fitzgerald, P. 2011. Low-temperature thermal history and landscape development of

924 the eastern Adirondack Mountains, New York: Constraints from apatite fission-track 925 thermochronology and apatite (U-Th)/He dating. Geological Society of America Bulletin, 123 (3-4), 926 412-426, doi: 10.1130/B30138.1.

927 Trompette, R. 1973. Le Précambrien et le Paléozoïque inférieur de l'Adrar de Mauritanie (bordure 928 occidentale du bassin de Taoudeni, Afrique de l'Ouest). Un exemple de sédimentation de craton. 929 Etude stratigraphique et sédimentologique. Travaux du Laboratoire de Sciences de la Terre, St930 Jérôme, Marseille.

931 Tucholke, B.E., Sawyer, D.S. \& Sibuet, J.C. 2007. Breakup of the Newfoundland-Iberia rift. In: Karner, 932 G.D., Manatschal, G. \& Pinheiro, L.M. (eds) Imaging, Mapping and Modelling Continental Lithosphere 933 Extension and Breakup, Geological Society, London, Special Publications, 282, 9-46, doi: $934 \quad 10.1144 / S P 282.2$.

935 Turner, J.P., Green, P.F., Holford, S.P. \& Lawrence, S.R. 2008. Thermal history of the Rio Muni)-NE 936 Brazil margins during continental breakup. Earth and Planetary Science Letters, 270, 354-367, doi: 937 doi:10.1016/j.epsl.2008.04.002.

938 Verati, C., Bertrand, H. \& Féraud, G. 2005. The farthest record of the Central Atlantic Magmatic 939 Province into West Africa Craton: Precise ${ }^{40} \mathrm{Ar} /{ }^{39} \mathrm{Ar}$ dating and geochemistry of Taoudenni basin 940 intrusives (northern Mali). Earth and Planetary Science Letters, 235, 391-407, 941 doi:10.1016/j.epsl.2005.04.012.

942 Verati, C., Rapaille, C., Féraud, G., A. Marzoli, Bertrand, H. \& Youbi, N. 2007. ${ }^{40} \mathrm{Ar} /{ }^{39} \mathrm{Ar}$ ages and 943 duration of the Central Atlantic Magmatic Province volcanism in Morocco and Portugal and its 
relation to the Triassic-Jurassic boundary. Palaeogeography, Palaeoclimatology, Palaeoecology, 244, 308-325, doi:10.1016/j.paleo.2006.06.033.

Villeneuve, M. 2008. Review of the orogenic belts on the western side of the West African craton: the Bassarides, Rokelides and Mauritanides. In: Ennih, N., \& J.P. Liégeois, J.P. (eds.), The boundaries of the West African Craton, Geological Society, London, Special Publications, 297, 169-201, doi: 10.1144/SP297.8.

von Rad, U., \& Sarti, M. 1986. Early Cretaceous "events" in the evolution of the eastern and western North Atlantic continental margins. Geologische Rundschau, 75 (1), 139-158, doi:10.1007/BF01770184.

von Rad, U., Hinz, K., Sarnthein, M. \& Seibold, E. 1982. Geology of the Northwest African Continental Margin, Springer, Berlin, Heidelberg.

Wade, J.A. \& McLean, B.C. 1990. The Stratigraphy of Georges Bank Basin and Relationships To the Scotian Basin. In: Keen, M.J. \& Williams, G.L. (eds) Geology of the Continental Margin of Eastern Canada, Geological Survey of Canada, Geology of Canada Series, 2, 190-238.

Wang, H.F., Crowley, K.D. \& Nadon, G.C. 1994. Thermal History of the Michigan Basin from Apatite Fission-Track Analysis and Vitrinite Reflectance. In: Ortoleva, P.J. (ed.) Basin Compartments and Seals, AAPG Special Volume, M61.

Wildman, M., Brown, R.W., Watkins, R., Carter, A., Gleadow, A. \& Summerfield, M. 2015. Post breakup tectonic inversion across the southwestern cape of South Africa: New insights from apatite and zircon fission track thermochronometry. Tectonophysics, 654, 30-55, doi:10.1016/j.tecto.2015.04.012. 
Fig. 1: Geological map of the Reguibat Shield and location of the samples. (a) Geographical location of 969 the studied area. The Reguibat Shield belongs to the NWAC, bounded to the East by the Panafrican 970 suture, separating it from the Tuareg Shield. Tf: Tindouf Basin; Td: Taoudeni Basin; Iu: Iullemeden 971 Basin; Ah: Ahnet Basin; O.M: Oued Mya Basin; Gh: Ghadames Basin. (b) Geological map of the Reguibat Shield. TLDB: Tarfaya-Laayoune-Dakhla Basin. Samples have black or grey labels depending on whether they are published or new data, respectively. Mixed labels (e.g. TGH4072A) indicate that AFT data have been published but AHe data are new. Cret. : Cretaceous. (c) Simplified stratigraphical log of the TLDB (modified after Leprêtre et al., 2015). 1: conglomerates and coarse detrital sediments; 2: coarse to fine sandstones; 3 : shales with variable sandy proportion; 4: Shales and clays, sometimes interbedded with limestones; 5: limestones.

Fig. 2: Segmentation of the Reguibat shield based on the LTT results. The data are projected along a NW-SE transect, perpendicular to the Central Atlantic passive margin. AHe ages are Ft corrected ages. Errors for AFT and AHe ages are indicated at $2 \sigma$. The distinction between the three domains of the Reguibat Shield is evidenced by the dispersion of the data and discussed in the text (section Sampling). Red outlines correspond to new data.

Fig. 3: AFT age vs. MTL plot for the whole Reguibat Shield. The grey bar indicates the timing and duration of the Jurassic rifting up to break-up, as defined by Labails et al. (2010).

Fig. 4: Track length distributions for all samples. They are separated by geographical area. Samples with more than 50 measured confined lengths have their names in black boxes. Reguibat Shield; (c) for the western Reguibat Shield. (d-i) Raw AHe ages vs. eU plots for the eastern colored areas underline the grouping of single-grain AHe ages. 
Fig. 6: Representative individual modeling for each domain of the Reguibat Shield. (a) Thermal modeling of sample GH3 in the eastern Reguibat Shield. (b) Predicted single-grain AHe ages against measured ones. Ages are corrected for Ft. (c) Predicted AFT data against measured ones. (d), (e) and (f) show the thermal modeling results for sample TGH3163 in the central Reguibat Shield, with the same legend than (a), (b) and (c), respectively. (g) and (h) show the thermal modeling results for sample AG167 in the western Reguibat Shield, with the same legend than (a) and (c), respectively.

Fig. 7: Inverse thermal modelings for the three Reguibat Shield domains. (a-c) Thermal modeling results for the eastern Reguibat Shield (a), for the central Reguibat Shield (b) and for the western Reguibat Shield (after Leprêtre et al., 2015 for AOS, SC, TAS233 and TAS29 samples) (c). The light grey box indicates in each panel the duration of the major cooling event. The dark grey box in (b-c) shows the duration of the subsequent reheating, which is not recorded in the eastern Reguibat Shield (a). For the western domain, black thermal paths correspond to the thermal modelings realized by Leprêtre et al. (2015). Due to the new AHe data, we have made new thermal modeling for the data from the central domain obtained by Leprêtre et al. (2014). For all modelings, the way we have defined the constraint-boxes is explained within the text.Fig. 8: Forward modeling for the central Reguibat Shield. (a) Tested thermal paths with HeFTy software (Ketcham, 2005). (b) Corresponding predicted AHe ages for each tested thermal path in (a). The measured Ft-corrected single-grain AHe ages are also indicated to ensure direct comparison. A small simplified map of the Reguibat Shield shows the segmentation between the different domains.

Fig. 8: Forward and inverse modeling for the central Reguibat Shield. (a) Tested thermal paths with HeFTy software (Ketcham, 2005). (b) Corresponding predicted AHe ages for each tested thermal path in (a).

Fig. 9: Comparison between AFT datasets of the conjugate passive margins of the northern Central Atlantic Ocean. (a, b) DEMs of Northeast America and Northwest Africa, respectively. Colored dots locate the AFT samples of the different studies quoted in the text with a color scale for the range of 
AFT ages. White lines are the profiles used to project the data with respect to the hinge line. (c, d) AFT datings along perpendicular profiles, from the hinge line at $x=0$. For the African AFT profile, data are from: Ghorbal et al. (2008); Saddiqi et al. (2009); Ruiz et al. (2011); Oukassou et al. (2013), Leprêtre et al. $(2014,2015)$ and this study. For the American profile, data come from the studies quoted in the text. Smaller panels on each profile show the MTL vs. AFT age plot. The grey bar indicates the age range of the rifting of the Central Atlantic Ocean (Labails et al., 2010).

Fig. 10: Comparison of Middle Jurassic-Aptian stratigraphical record of Central Atlantic Ocean conjugate passive margins. The map at the bottom shows the approximate position of North America and West Africa at Chron 25 (154 Ma). Continent contours and the $2 \mathrm{~km}$-depth bathymetry are the present-day ones. The basins whose stratigraphy is described in the text are located in dark grey. The margins have been divided into a northern and a southern segment, given their respective stratigraphy. Only one stratigraphical log is used for the northern segment since all basins shared a common evolution during the considered period. Legend for sedimentary rocks: 1 . marls; 2 . carbonates; 3 . Dolomites, 4. siltstones and marls; 5 . coarse clastics; 6 . sandstones to siltstones. Legend for the period described on the stratigraphic logs: EJ. Early Jurassic; MJ: Middle Jurassic; LJ: Late Jurassic; NC: Neocomian (Berriasian-Hauterivian); BAP: Barremian-Aptian.

Fig. 11: Evolution of the spreading rates in the Central Atlantic Ocean from Early Jurassic to Early Cretaceous. This compilation is based on works by Schettino \& Turco (2009), Labails et al. (2010) and Kneller et al. (2012).

Fig. 12: Representative thermal paths from the onshore eastern North America. Thermal paths are coming from: (a) Nova Scotia in the northern proximal passive margin (Grist \& Zentili, 2003); (b) the Michigan Basin, deep in the interior of the continent (Wang et al., 1994); (c) the southern Canadian Shield (Lorencak et al., 2004); (d) the Northern Appalachian (Taylor \& Fitzgerald, 2011). Dark grey box defines the main period of uplift in the western and central Reguibat Shield domains in the conjugated African passive margin. 


\begin{tabular}{|c|c|c|c|c|c|c|c|c|c|c|c|c|c|}
\hline & Sample & Rock-type & Location & $\begin{array}{l}\text { Elevation } \\
\text { (m) }\end{array}$ & $\begin{array}{c}\rho_{\mathrm{s}}\left(10^{5} . \mathrm{cm}^{-2}\right) \\
/ \mathrm{Ns}\end{array}$ & $\begin{array}{c}\rho_{\mathrm{i}}\left(10^{5} . \mathrm{cm}^{-2}\right) \\
/ \mathrm{Ni}\end{array}$ & $\begin{array}{c}\rho_{\mathrm{d}}\left(10^{5} . \mathrm{cm}-{ }^{2}\right) \\
/ \mathrm{Nd}\end{array}$ & $P\left(\chi^{2}\right) \%$ & $\begin{array}{c}\text { Central age } \\
(\mathrm{Ma}) \pm 1 \sigma\end{array}$ & $\begin{array}{c}U \\
(p p m)\end{array}$ & $\begin{array}{c}\text { MTL }(\mu \mathrm{m}) \pm \\
\text { se }\end{array}$ & $\begin{array}{l}\text { Std } \\
\text { dev. }\end{array}$ & Dpar $(\mu \mathrm{m})$ \\
\hline \multirow[t]{2}{*}{$\begin{array}{l}\text { Western } \\
\text { domain }\end{array}$} & AG167 & charnockite & $\begin{array}{l}13^{\circ} 24^{\prime} 2.07 " \mathrm{~W} \\
20^{\circ} 42^{\prime} 56.76 " \mathrm{~N}\end{array}$ & 233 & $\begin{array}{c}0.218 \\
323\end{array}$ & $\begin{array}{c}0.195 \\
289\end{array}$ & $\begin{array}{l}6.73 \\
6849\end{array}$ & 74 & $\begin{array}{c}137 \pm 12 \\
(20)\end{array}$ & 4 & $\begin{array}{l}- \\
-\end{array}$ & $\begin{array}{l}- \\
-\end{array}$ & $1.72 \pm 0.1$ \\
\hline & AG169 & charnockite & $\begin{array}{l}13^{\circ} 24^{\prime} 2.07^{\prime \prime} \mathrm{W} \\
20^{\circ} 42^{\prime} 56.76^{\prime \prime} \mathrm{N}\end{array}$ & 237 & $\begin{array}{c}0.201 \\
309\end{array}$ & $\begin{array}{c}0.207 \\
319\end{array}$ & $\begin{array}{l}6.682 \\
6849\end{array}$ & 93 & $\begin{array}{c}118 \pm 10 \\
(20)\end{array}$ & 4 & - & - & $1.54 \pm 0.2$ \\
\hline \multirow[t]{4}{*}{$\begin{array}{l}\text { Central } \\
\text { domain }\end{array}$} & TGH3111B & granite & $\begin{array}{l}9^{\circ} 22^{\prime} 12^{\prime \prime} \mathrm{W} \\
24^{\circ} 00^{\prime} 00^{\prime \prime} \mathrm{N}\end{array}$ & 252 & $\begin{array}{l}3.246 \\
1097\end{array}$ & $\begin{array}{c}2.598 \\
878\end{array}$ & $\begin{array}{l}6.611 \\
6563\end{array}$ & 65 & $\begin{array}{c}150 \pm 8 \\
(20)\end{array}$ & 48 & $\begin{array}{c}11.9 \pm 0.2 \\
(101)\end{array}$ & 1.7 & $1.63 \pm 0.1$ \\
\hline & TEN4065 & microgranite & $\begin{array}{l}10^{\circ} 1 ' 47.00^{\prime \prime W} \\
24^{\circ} 20^{\prime} 23.00^{\prime \prime} \mathrm{N}\end{array}$ & 258 & $\begin{array}{c}6.444 \\
883\end{array}$ & $\begin{array}{c}4.462 \\
477\end{array}$ & $\begin{array}{l}6.595 \\
6563\end{array}$ & 8 & $\begin{array}{c}172 \pm 13 \\
(20)\end{array}$ & 82 & $\begin{array}{c}11.7 \pm 0.3 \\
(35)\end{array}$ & 2 & $2.06 \pm 0.5$ \\
\hline & AL10 & granodiorite & $\begin{array}{c}7^{\circ} 7^{\prime} 5.15^{\prime \prime W} \\
26^{\circ} 37^{\prime} 33.06^{\prime \prime N}\end{array}$ & 394 & $\begin{array}{c}1.334 \\
675\end{array}$ & $\begin{array}{c}0.866 \\
438\end{array}$ & $\begin{array}{l}7.255 \\
6849\end{array}$ & 63 & $\begin{array}{c}202 \pm 14 \\
(20)\end{array}$ & 15 & $\begin{array}{c}12 \pm 0.2 \\
(49)\end{array}$ & 1.6 & $1.77 \pm 0.1$ \\
\hline & YT7 & monzogranite & $\begin{array}{l}7^{\circ} 20^{\prime} 37.34 " \mathrm{~W} \\
26^{\circ} 28^{\prime} 59.39 " \mathrm{~N}\end{array}$ & 384 & $\begin{array}{l}1.862 \\
1380\end{array}$ & $\begin{array}{l}1.394 \\
1033\end{array}$ & $\begin{array}{l}6.825 \\
6849\end{array}$ & 72 & $\begin{array}{c}166 \pm 8 \\
(20)\end{array}$ & 25 & $\begin{array}{c}11.4 \pm 0.3 \\
(49)\end{array}$ & 1.8 & $1.60 \pm 0.2$ \\
\hline \multirow[t]{8}{*}{$\begin{array}{l}\text { Eastern } \\
\text { domain }\end{array}$} & IG3 & rhyolite & $\begin{array}{c}6^{\circ} 9^{\prime} 0.43 " \mathrm{~W} \\
26^{\circ} 6^{\prime} 22.40^{\prime \prime} \mathrm{N}\end{array}$ & 366 & $\begin{array}{c}0.469 \\
543\end{array}$ & $\begin{array}{c}0.149 \\
172\end{array}$ & $\begin{array}{l}6.968 \\
6849\end{array}$ & 84 & $\begin{array}{c}393 \pm 36 \\
(20)\end{array}$ & 3 & - & - & $1.66 \pm 0.2$ \\
\hline & $\mathrm{CH} 1$ & gabbrodiorite & $\begin{array}{l}3^{\circ} 35^{\prime} 36.69 " \mathrm{~W} \\
25^{\circ} 35^{\prime} 45.94^{\prime \prime} \mathrm{N}\end{array}$ & 252 & $\begin{array}{c}1.098 \\
862\end{array}$ & $\begin{array}{c}0.454 \\
356\end{array}$ & $\begin{array}{l}7.159 \\
6849\end{array}$ & 6 & $\begin{array}{c}307 \pm 26 \\
(20)\end{array}$ & 8 & $\begin{array}{c}11.5 \pm 0.2 \\
(101)\end{array}$ & 2.1 & $1.86 \pm 0.2$ \\
\hline & $\mathrm{CH} 2$ & gabbrodiorite & $\begin{array}{c}3^{\circ} 35^{\prime} 36.69 " \mathrm{~W} \\
25^{\circ} 35^{\prime} 45.94 " \mathrm{~N}\end{array}$ & 252 & $\begin{array}{c}3.105 \\
770\end{array}$ & $\begin{array}{c}1.516 \\
376\end{array}$ & $\begin{array}{l}7.112 \\
6849\end{array}$ & 18 & $\begin{array}{l}264 \pm 21 \\
(20)\end{array}$ & 26 & $\begin{array}{c}12 \pm 0.2 \\
(69)\end{array}$ & 1.7 & $1.99 \pm 0.2$ \\
\hline & $\mathrm{CH} 3$ & gabbrodiorite & $\begin{array}{c}3^{\circ} 35^{\prime} 36.69 " \mathrm{~W} \\
25^{\circ} 35^{\prime} 45.94^{\prime \prime} \mathrm{N}\end{array}$ & 252 & $\begin{array}{c}1.059 \\
686\end{array}$ & $\begin{array}{c}0.426 \\
276\end{array}$ & $\begin{array}{l}7.064 \\
6849\end{array}$ & 86 & $\begin{array}{c}315 \pm 24 \\
(20)\end{array}$ & 7 & $\begin{array}{c}11.5 \pm 0.3 \\
(64)\end{array}$ & 2.3 & $1.95 \pm 0.2$ \\
\hline & $\mathrm{GH} 3$ & trondhjemite & $\begin{array}{c}6^{\circ} 3^{\prime} 54.77^{\prime \prime} \mathrm{W} \\
25^{\circ} 29^{\prime} 36.53 " \mathrm{~N}\end{array}$ & 360 & $\begin{array}{l}1.177 \\
1130\end{array}$ & $\begin{array}{l}0.41 \\
394\end{array}$ & $\begin{array}{l}7.016 \\
6849\end{array}$ & 6 & $\begin{array}{c}359 \pm 27 \\
(20)\end{array}$ & 7 & $\begin{array}{c}11.5 \pm 0.2 \\
(100)\end{array}$ & 1.9 & $1.76 \pm 0.2$ \\
\hline & DEG6 & gabbro & $\begin{array}{l}2^{\circ} 57^{\prime} 15.60^{\prime \prime} \mathrm{W} \\
26^{\circ} 4^{\prime} 50.02^{\prime \prime} \mathrm{N}\end{array}$ & 355 & $\begin{array}{l}2.276 \\
1065\end{array}$ & $\begin{array}{c}0.701 \\
328\end{array}$ & $\begin{array}{l}6.111 \\
6849\end{array}$ & 46 & $\begin{array}{c}355 \pm 25 \\
(20)\end{array}$ & 12 & $\begin{array}{c}11.2 \pm 0.4 \\
(27)\end{array}$ & 2.1 & $1.97 \pm 0.1$ \\
\hline & $\mathrm{GH} 20$ & gabbro & $\begin{array}{c}6^{\circ} 0 ' 2.87 " \mathrm{~W} \\
25^{\circ} 32^{\prime} 51.89 " \mathrm{~N}\end{array}$ & 350 & $\begin{array}{c}0.471 \\
206\end{array}$ & $\begin{array}{c}0.101 \\
44\end{array}$ & $\begin{array}{l}5.996 \\
3012\end{array}$ & 73 & $\begin{array}{c}497 \pm 61 \\
(10)\end{array}$ & 2 & $\begin{array}{l}- \\
-\end{array}$ & - & $1.75 \pm 0.1$ \\
\hline & TL3 & gabbro & $\begin{array}{l}3^{\circ} 10^{\prime} 37.45 " \mathrm{~W} \\
27^{\circ} 21^{\prime} 31.99 " \mathrm{~N}\end{array}$ & 381 & $\begin{array}{c}0.818 \\
447\end{array}$ & $\begin{array}{c}0.376 \\
207\end{array}$ & $\begin{array}{l}6.052 \\
3012\end{array}$ & 66 & $\begin{array}{c}237 \pm 21 \\
(20)\end{array}$ & 8 & $\begin{array}{l}- \\
-\end{array}$ & - & $2.12 \pm 0.2$ \\
\hline
\end{tabular}


* $\rho$ - density of tracks with $\mathrm{s}$ and $\mathrm{i}-$ spontaneous and induced densities in apatite crystals and the mica detector; $\mathrm{d}-$ tracks density of the neutron glass

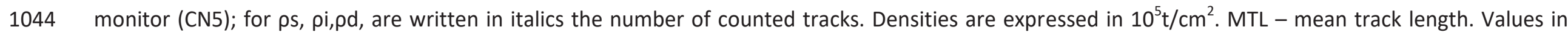

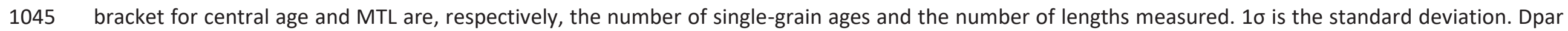
1046 corresponds to a kinetic factor determined for each sample (Barbarand et al., 2003).

1047

1048

1049 


\begin{tabular}{|c|c|c|c|c|c|c|c|c|c|c|c|}
\hline & Name & $\operatorname{Rs}(\mu \mathrm{m})$ & Weight( $\mu \mathrm{g})$ & $\mathbf{F}_{T}$ & ${ }^{4} \mathrm{He}(\mathrm{ncc} / \mathrm{g})$ & $U$ (ppm) & Th (ppm) & Sm (ppm) & eU (ppm) & Age (Ma) & Age c. (Ma) \\
\hline Central & $1153-A$ & 80.8 & 11.85 & 0.87 & 46201.6 & 3.8 & 11.9 & 7.0 & 6.7 & 57 & $66 \pm 5$ \\
\hline \multirow[t]{19}{*}{ Domain } & $1153 D$ & 34.4 & 1.17 & 0.715 & 120399,0 & 10.4 & 31.9 & 20.3 & 18.3 & 55 & $77 \pm 6$ \\
\hline & $1153-\mathrm{F}$ & 63.2 & 6.54 & 0.815 & 100000.8 & 7.6 & 20.3 & 9.5 & 12.6 & 66 & $81 \pm 6$ \\
\hline & $1153-\mathrm{H}$ & 59 & 4.69 & 0.83 & 63086.4 & 11.2 & 22.6 & 12.5 & 16.7 & 31 & $38 \pm 3$ \\
\hline & |-1153 & 47.5 & 2.56 & 0.79 & 57756,0 & 5.5 & 16.8 & 13.3 & 9.6 & 50 & $63 \pm 5$ \\
\hline & 3163-A & 54.1 & 3.6 & 0.809 & 717183.1 & 37.7 & 1.9 & 27.2 & 38.3 & 155 & $191 \pm 15$ \\
\hline & 3163-E & 66 & 7.11 & 0.827 & 288616.5 & 16.9 & 1.4 & 17.6 & 17.4 & 137 & $166 \pm 13$ \\
\hline & I-3163 & 65.6 & 6.26 & 0.847 & 470679.8 & 17.8 & 25.6 & 24.6 & 24.1 & 162 & $191 \pm 15$ \\
\hline & $3163 G$ & 96.1 & 17.27 & 0.875 & 549045.6 & 25,0 & 22,0 & NA & 30.3 & 150 & $172 \pm 14$ \\
\hline & AL10-A & 46 & 2.4 & 0.755 & 405681.5 & 22.5 & 20.6 & 31.8 & 27.7 & 121 & $161 \pm 13$ \\
\hline & AL10-E & 39.3 & 1.18 & 0.701 & 675195,0 & 76.1 & 26.7 & 31.3 & 82.8 & 67 & $96 \pm 8^{*}$ \\
\hline & AL10-C & 50.5 & 3.53 & 0.765 & 229447.2 & 11.1 & 11.9 & 29.3 & 14.2 & 134 & $175 \pm 14$ \\
\hline & AL10-L & 44.1 & 1.57 & 0.679 & 1341456.8 & 34.3 & 31.1 & 59.4 & 42.2 & 263 & $388 \pm 31^{*}$ \\
\hline & AL10-J & 37.2 & 1.22 & 0.724 & 231868.3 & 7.9 & 10,0 & 37.4 & 10.5 & 182 & $252 \pm 20$ \\
\hline & AL10-I & 45.5 & 2.02 & 0.76 & 395904.9 & 22.4 & 14.9 & 41,0 & 26.3 & 124 & $164 \pm 13$ \\
\hline & AL10-B & 39 & 1.39 & 0.726 & 557702.2 & 20.6 & 11.6 & 37.5 & 23.7 & 195 & $269 \pm 21$ \\
\hline & AL10-K & 37.9 & 1.28 & 0.717 & 145483.1 & 12.5 & 8.8 & 35.5 & 14.9 & 81 & $112 \pm 9$ \\
\hline & AL10-F & 38.7 & 1.23 & 0.687 & 129286.7 & 9.5 & 15.8 & 44.8 & 13.6 & 79 & $115 \pm 9$ \\
\hline & AL10-G & 39.9 & 1.23 & 0.707 & 1327362.4 & 32.4 & 26.5 & 65.3 & 39.3 & 280 & $396 \pm 32 *$ \\
\hline & AL10-H & 42.6 & 1.58 & 0.713 & 236976.2 & 18.4 & 18.2 & 50.1 & 23.2 & 85 & $119 \pm 10$ \\
\hline Eastern & $\mathrm{CH} 1-\mathrm{A}$ & 47.3 & 2.43 & 0.789 & 79475.1 & 7.2 & 6.9 & 5.3 & 9 & 74 & $93 \pm 7$ \\
\hline
\end{tabular}




\begin{tabular}{|c|c|c|c|c|c|c|c|c|c|c|c|}
\hline \multirow[t]{2}{*}{ Domain } & CH1-B & 56.4 & 4.13 & 0.809 & 28513.1 & 2.7 & 3.2 & 1.4 & 3.5 & 68 & $84 \pm 7$ \\
\hline & $\mathrm{CH} 1-\mathrm{C}$ & 49.4 & 2.68 & 0.802 & 48729.7 & 13.1 & 11.1 & 5.3 & 15.8 & 26 & $32 \pm 3^{*}$ \\
\hline & CH1-D & 40.2 & 1.45 & 0.751 & 205297.8 & 10.1 & 12.5 & 5.6 & 13.1 & 130 & $173 \pm 14$ \\
\hline & $\mathrm{CH} 1-\mathrm{F}$ & 38.8 & 1.31 & 0.754 & 127741.1 & 11 & 9.6 & 3.4 & 13.3 & 80 & $106 \pm 8$ \\
\hline & $\mathrm{CH} 1-\mathrm{G}$ & 64 & 6.37 & 0.831 & 88950.2 & 6.2 & 8.5 & 5.1 & 8.2 & 90 & $108 \pm 9$ \\
\hline & $\mathrm{CH} 1-\mathrm{H}$ & 37.9 & 1.28 & 0.717 & 392039.3 & 26.1 & 23.4 & 6 & 31.8 & 102 & $143 \pm 11$ \\
\hline & CH1-J & 50.6 & 3.96 & 0.761 & 141712.3 & 5,0 & 6.5 & 4.5 & 6.6 & 178 & $234 \pm 19$ \\
\hline & $\mathrm{CH} 1-\mathrm{K}$ & 40.7 & 1.74 & 0.723 & 190623.3 & 19,0 & 10.3 & 14.9 & 21.6 & 73 & $101 \pm 8$ \\
\hline & $\mathrm{CH} 3-\mathrm{C}$ & 50.5 & 3.04 & 0.789 & 119938.2 & 4.2 & 5.9 & 3.7 & 5.7 & 175 & $222 \pm 18$ \\
\hline & $\mathrm{CH} 3-\mathrm{F}$ & 35.5 & 0.96 & 0.717 & 191786.5 & 13.4 & 11.3 & 4.2 & 16.1 & 99 & $138 \pm 11$ \\
\hline & $\mathrm{CH} 3-\mathrm{A}$ & 54.7 & 4.25 & 0.79 & 93992.9 & 5.7 & 5.5 & 3.2 & 7 & 111 & $141 \pm 11$ \\
\hline & $\mathrm{CH} 3-\mathrm{G}$ & 59.2 & 6.11 & 0.793 & 71842,0 & 3.7 & 5 & 2.7 & 4.9 & 122 & $153 \pm 12$ \\
\hline & GH3A & 66.1 & 7.49 & 0.823 & 292746.2 & 8.1 & 5.6 & 12.7 & 9.6 & 253 & $307 \pm 25$ \\
\hline & GH3B & 91.1 & 21.74 & 0.876 & 172995.7 & 4.7 & 4.6 & 6.4 & 5.9 & 243 & $278 \pm 22$ \\
\hline & GH3-C & 71.5 & 8.99 & 0.842 & 56806.1 & 4.5 & 3.5 & 8.9 & 5.4 & 88 & $104 \pm 8$ \\
\hline & GH3-E & 57.9 & 4.06 & 0.784 & 230520.3 & 6.5 & 3.8 & 10.8 & 7.5 & 256 & $326 \pm 26$ \\
\hline & GH3-F & 99 & 19.03 & 0.883 & 21444.4 & 1.7 & 0.4 & 2.2 & 1.8 & 98 & $111 \pm 9$ \\
\hline & IG3-C & 43.8 & 1.72 & 0.722 & 332846.2 & 18.1 & 18.9 & 44.7 & 23 & 120 & $166 \pm 13$ \\
\hline & IG3-E & 39.4 & 1.31 & 0.686 & 191182.1 & 5 & 10 & 48.9 & 7.8 & 203 & $295 \pm 24$ \\
\hline & IG3-F & 36.7 & 0.99 & 0.675 & 118582.6 & 3.8 & 10.9 & 47.2 & 6.8 & 146 & $216 \pm 17$ \\
\hline & IG3-G & 40.6 & 1.56 & 0.741 & 91106.9 & 3.7 & 4.9 & 38.8 & 5.1 & 147 & $198 \pm 16$ \\
\hline & IG3-I & 40.4 & 1.67 & 0.721 & 187725,0 & 3.9 & 5.5 & 49.9 & 5.6 & 277 & $384 \pm 31$ \\
\hline & TL3-L & 41.1 & 1.58 & 0.745 & 131554.4 & 6.3 & 18.8 & 29.8 & 11.1 & 99 & $133 \pm 11$ \\
\hline & TL3-B & 49.4 & 2.68 & 0.803 & 66784.2 & 8.8 & 17 & 23.8 & 13.1 & 42 & $53 \pm 4$ \\
\hline & TL3-C & 41.3 & 1.57 & 0.778 & 73141.8 & 9.2 & 43.5 & 27 & 19.8 & 31 & $40 \pm 3^{*}$ \\
\hline & TL3-D & 39 & 1.44 & 0.717 & 86327.5 & 6.3 & 20.9 & 33.8 & 11.6 & 62 & $87 \pm 7$ \\
\hline
\end{tabular}




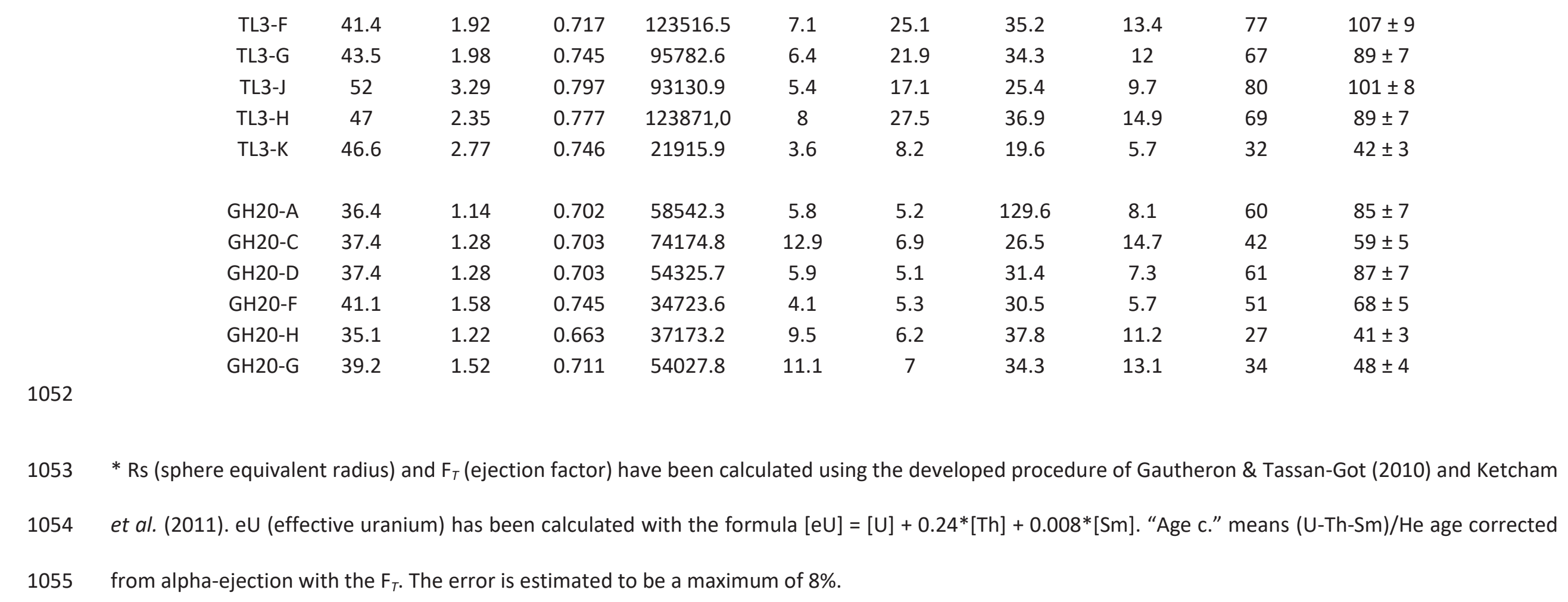


Figure 1
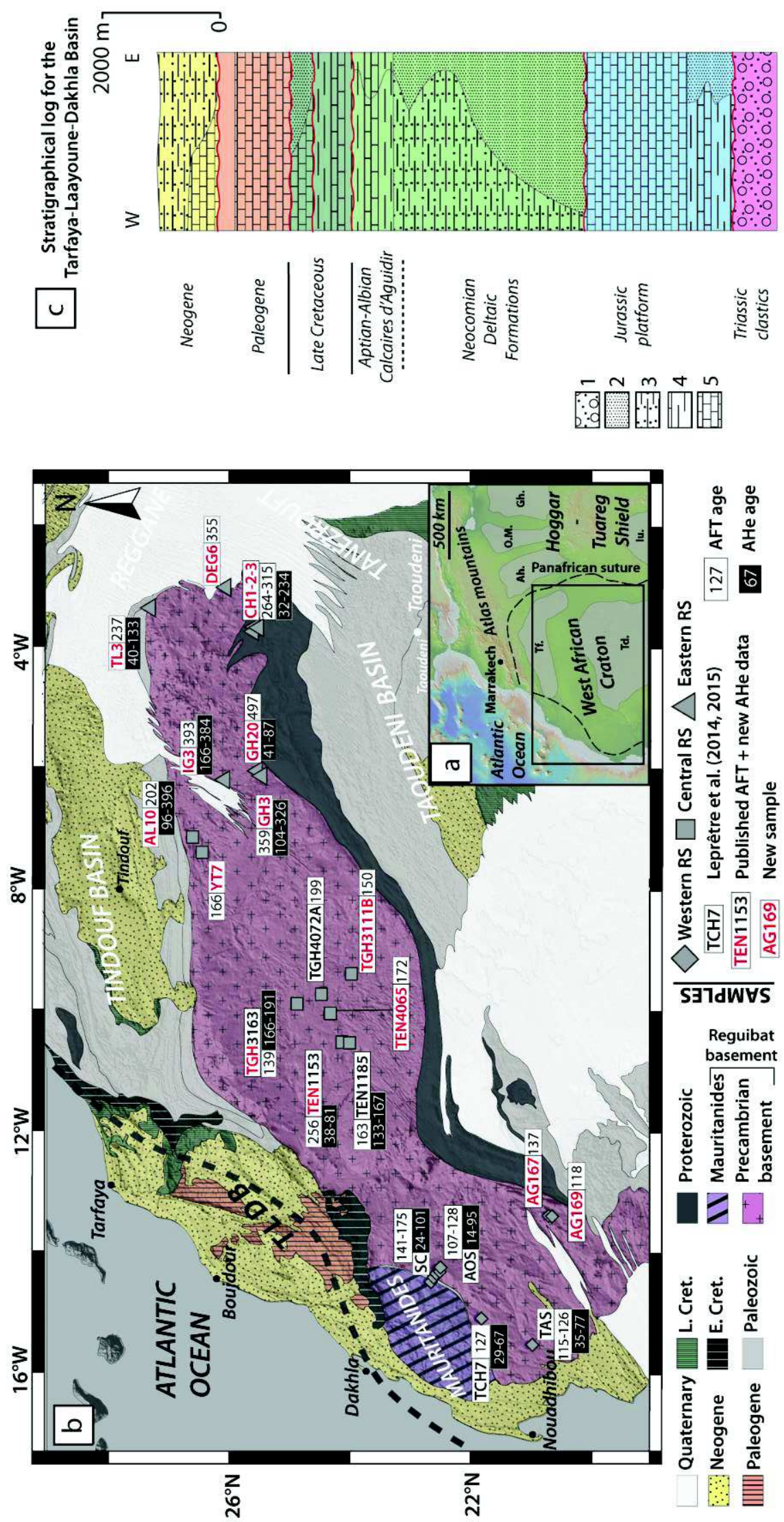
Figure 2

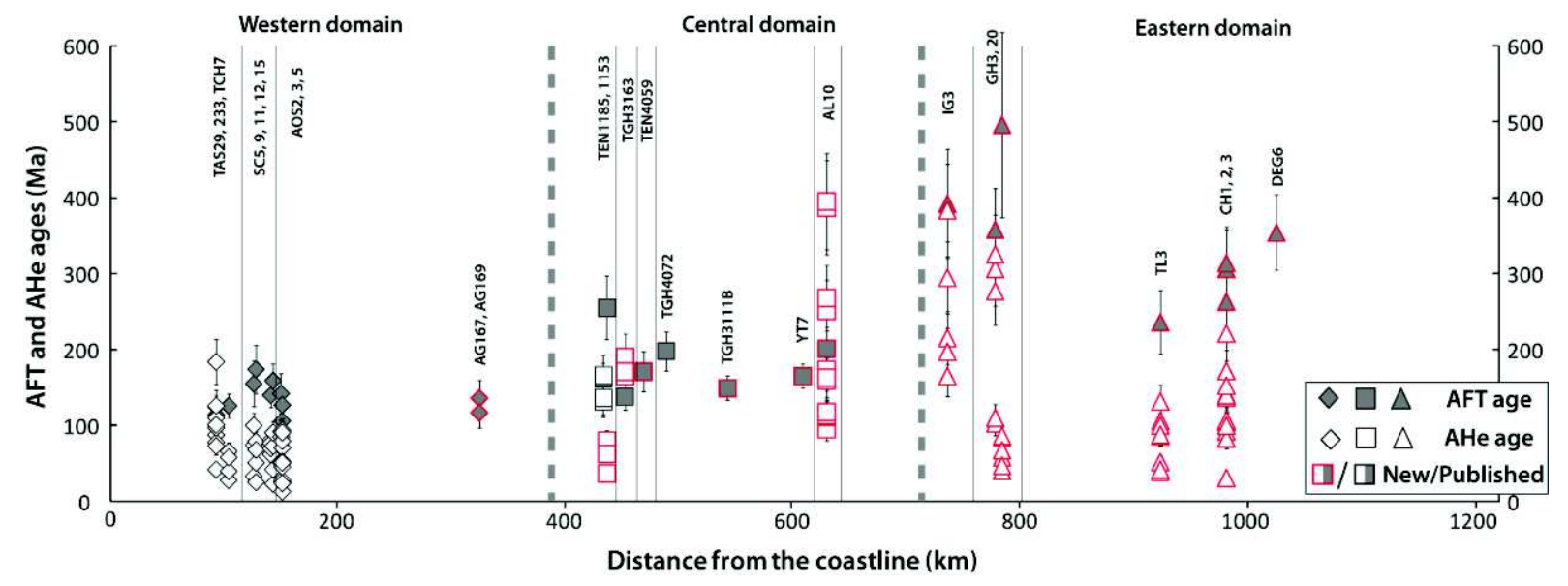

Figure 3

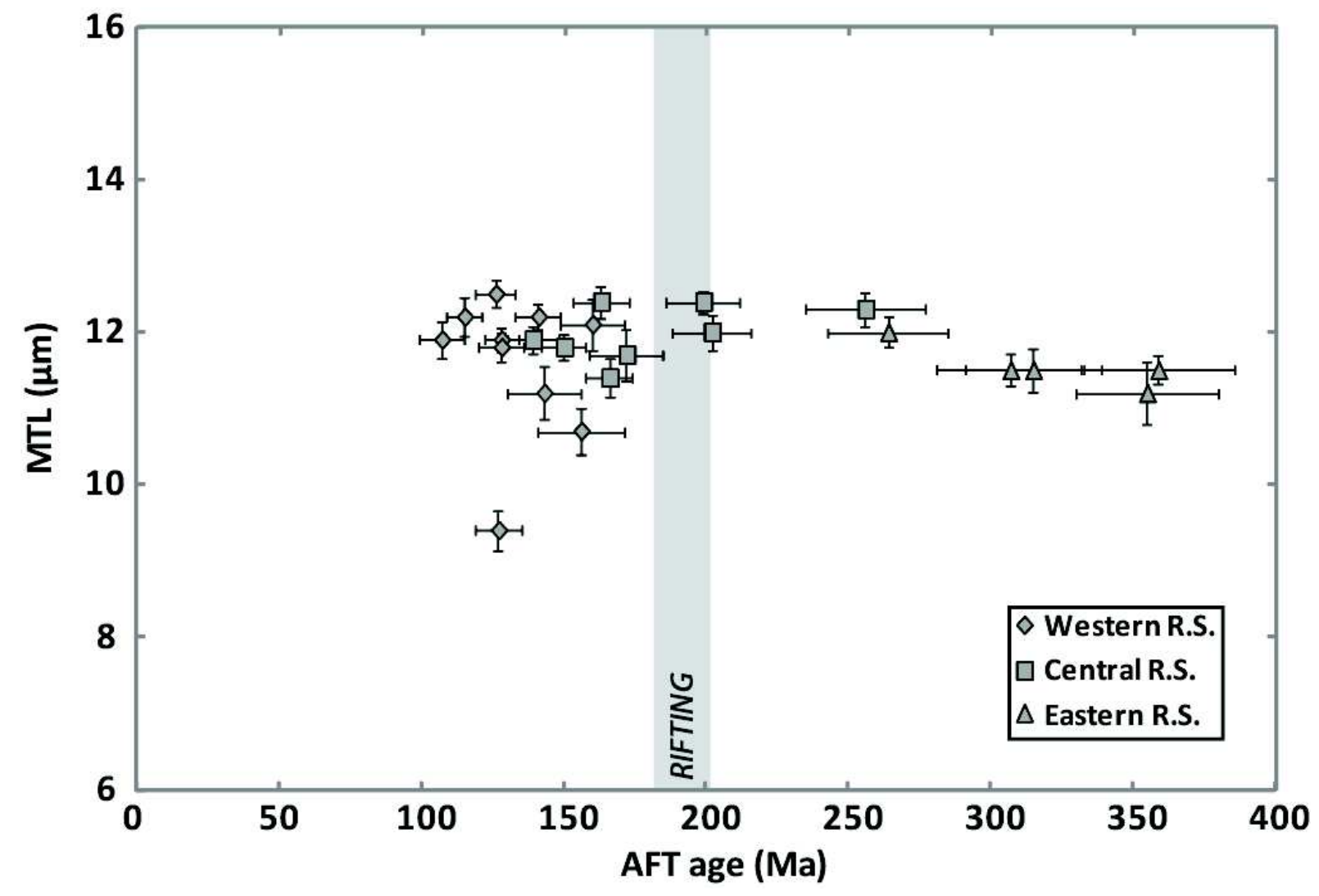


Figure 4
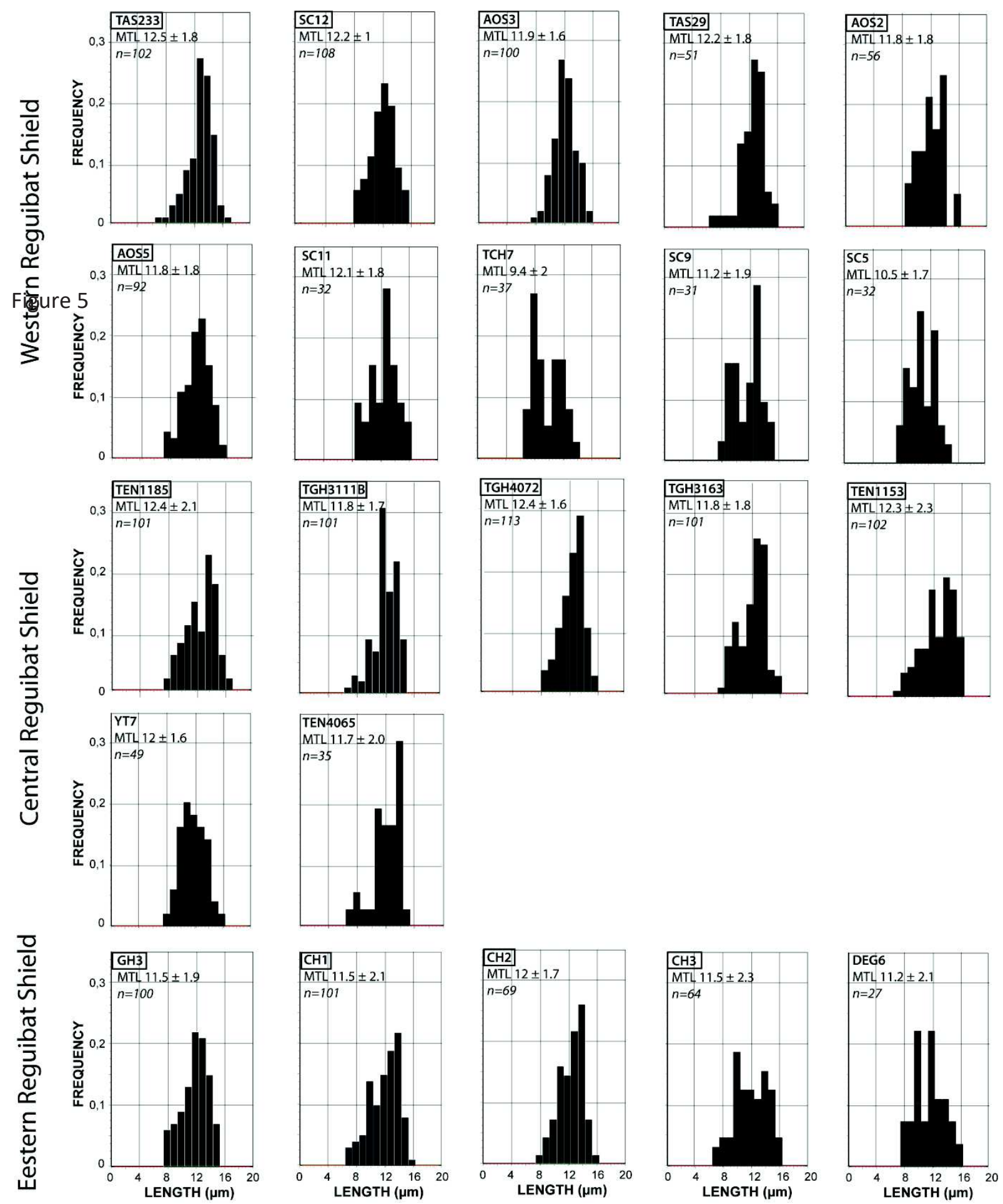
Figure 5
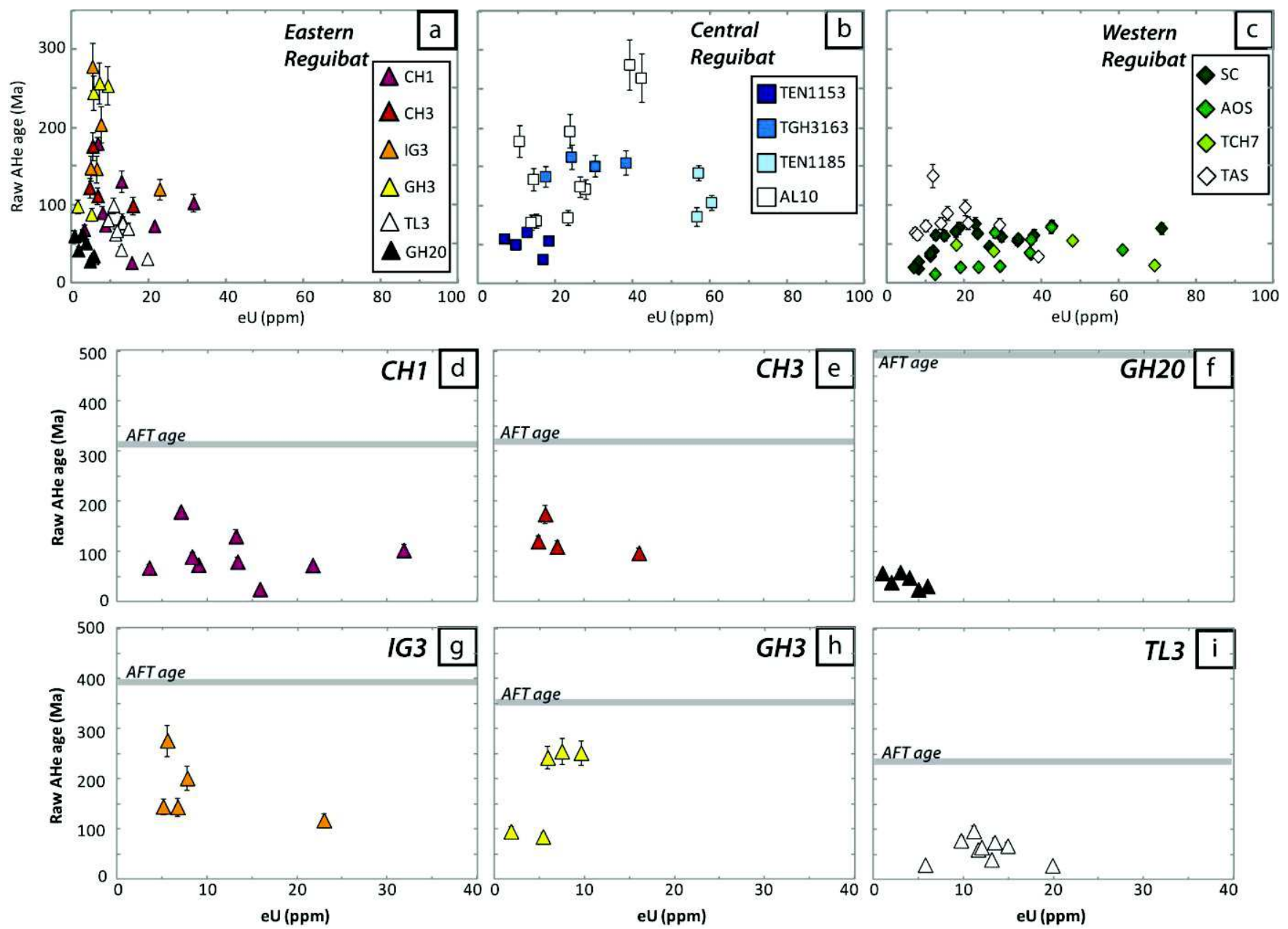
Figure 6
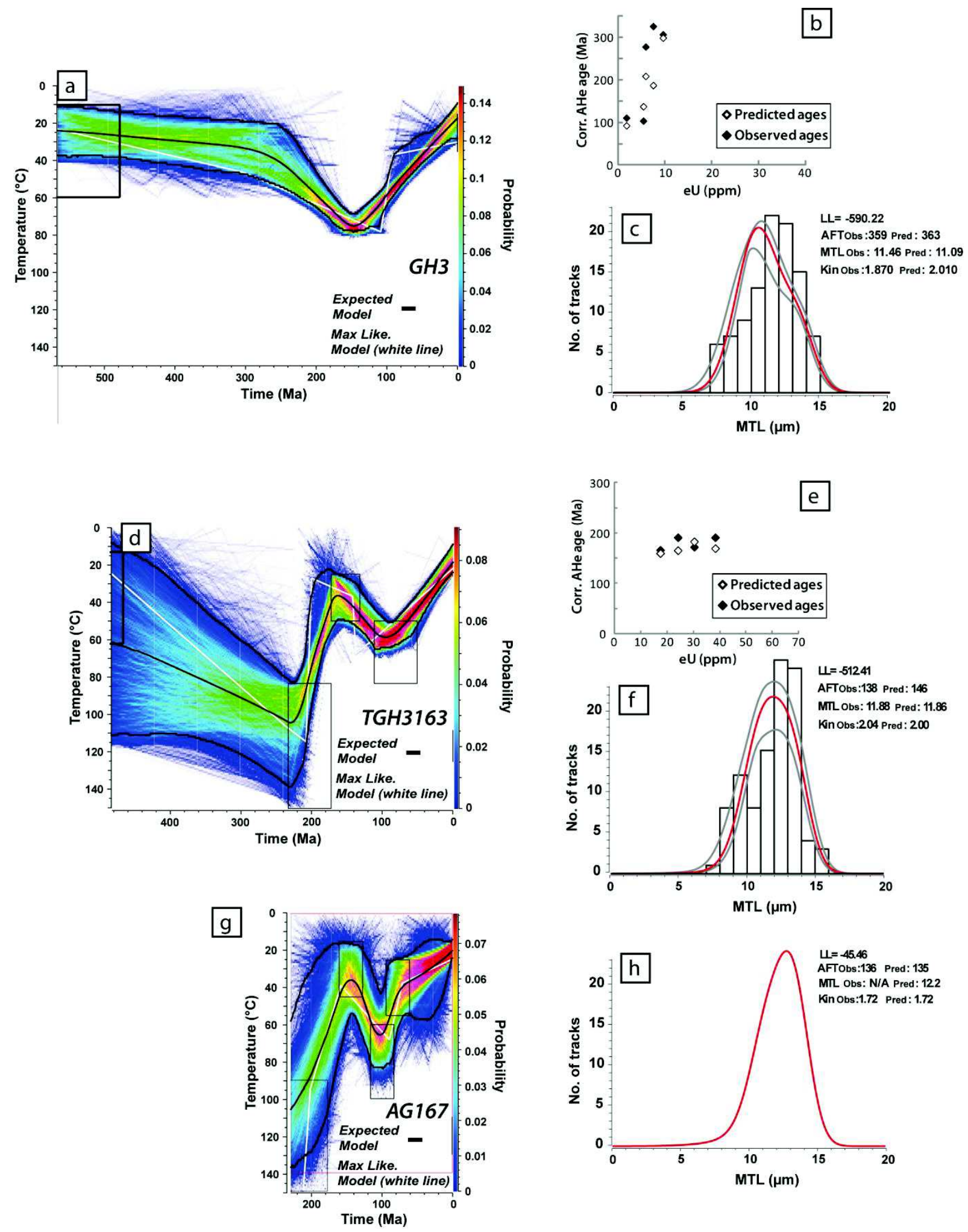
Figure 7

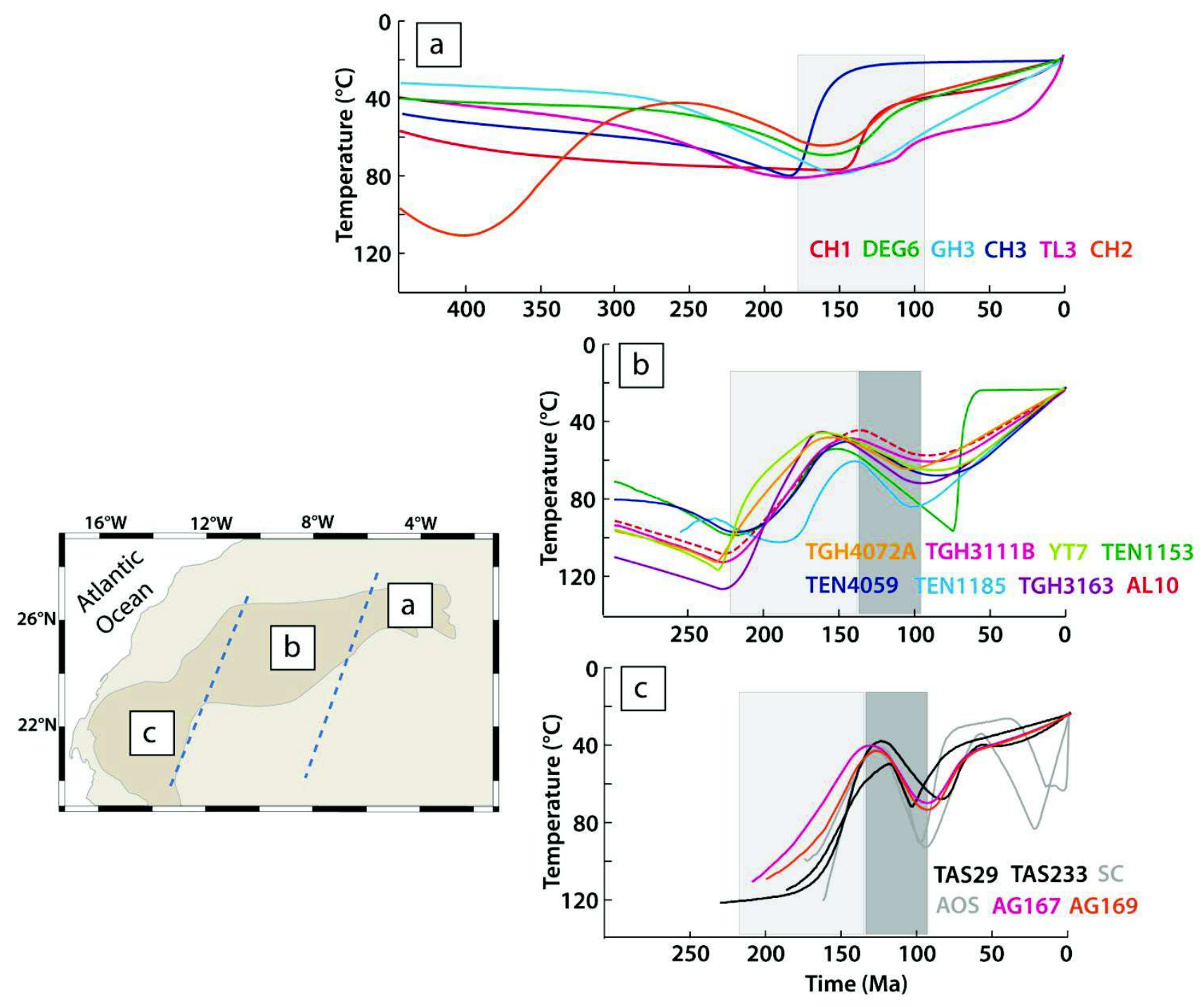


Figure 8
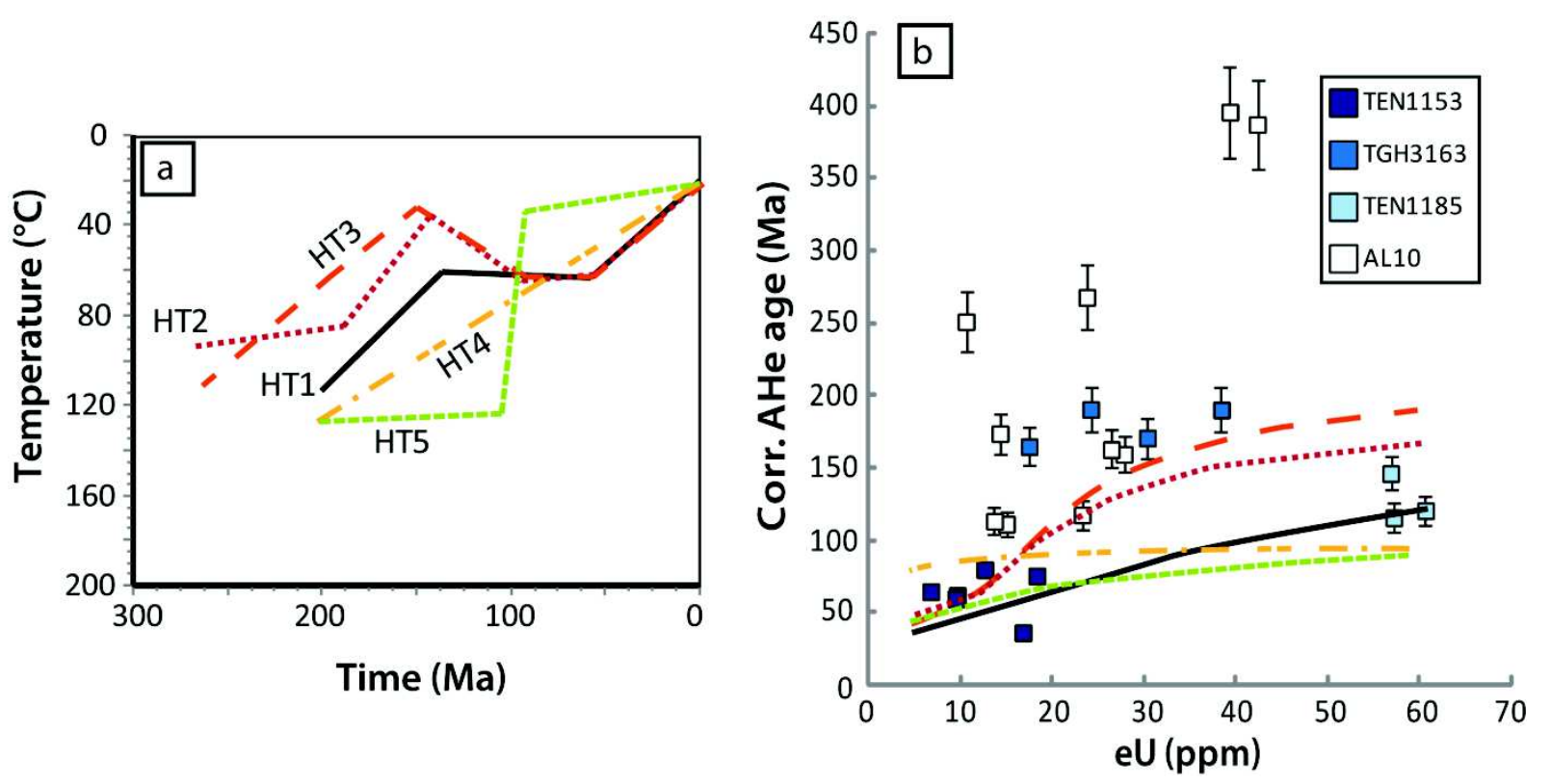
Figure 9
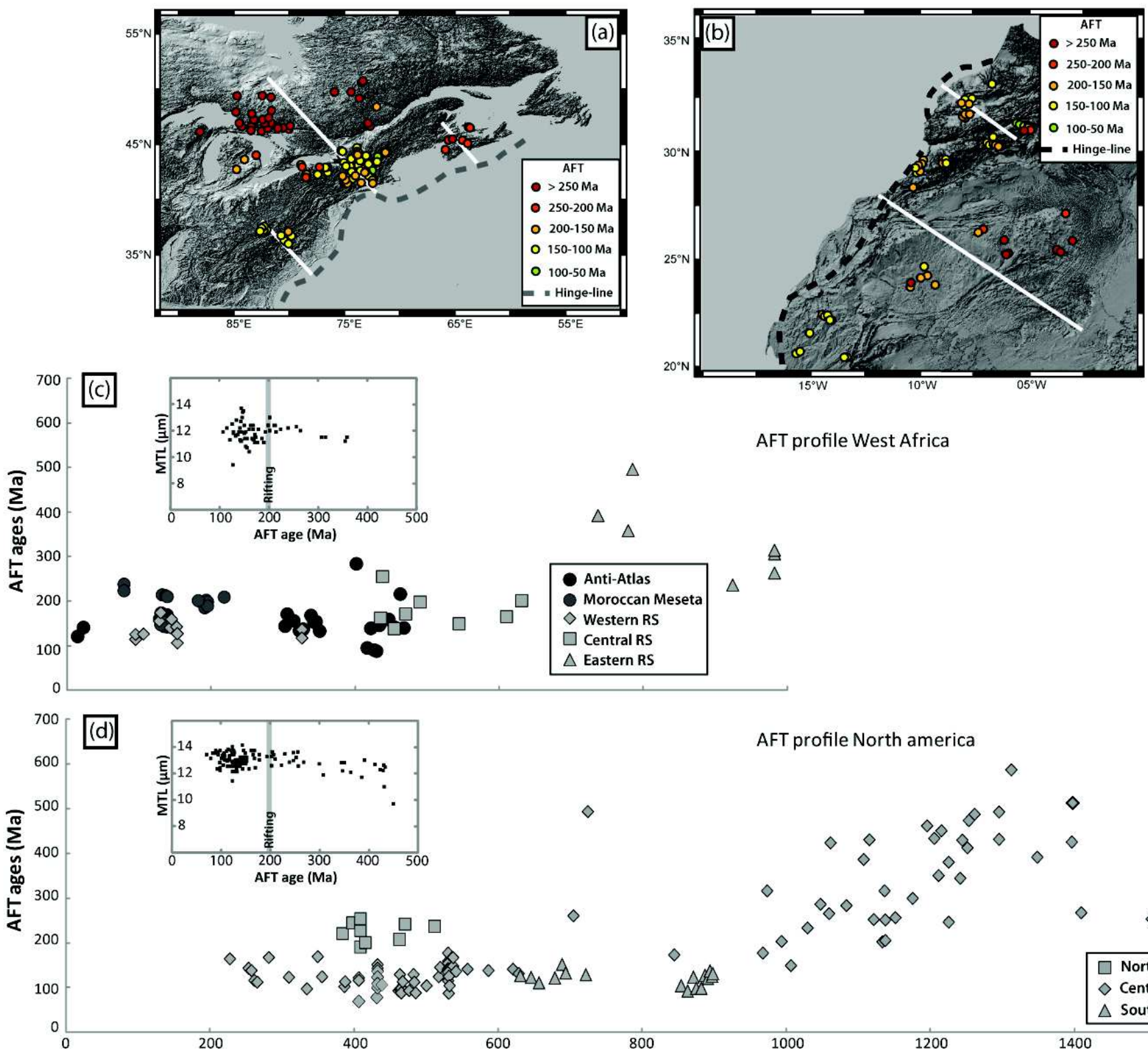

$\triangle$

$\triangle$

AFT profile West Africa

$\triangle$

Anti-Atlas

$\longrightarrow \triangle \triangle$

$\diamond$ Western RS

$\square$ Central RS

$\triangle$ Eastern RS

鸺 무

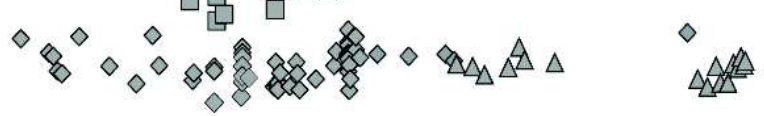

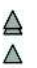

(n) 


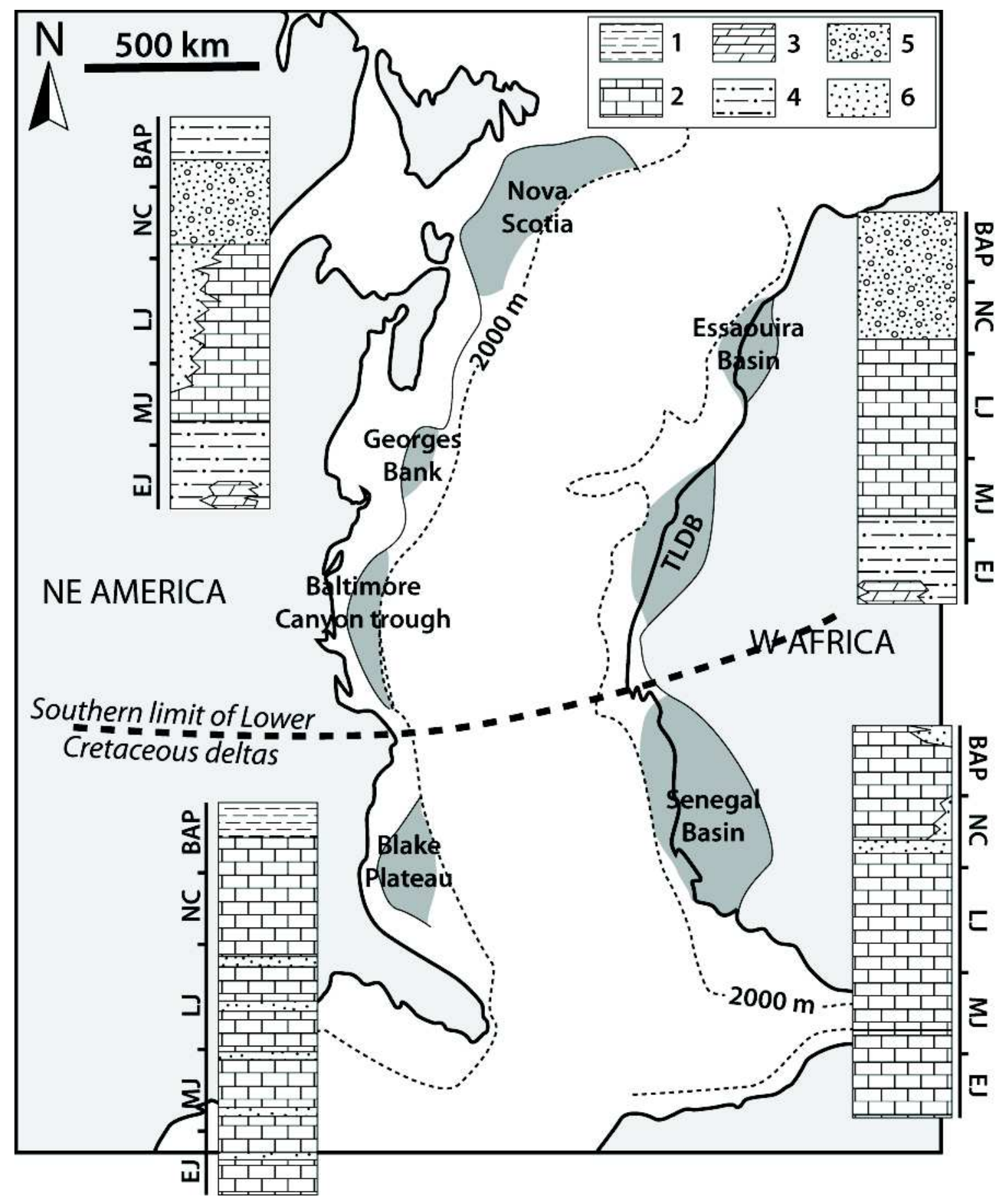




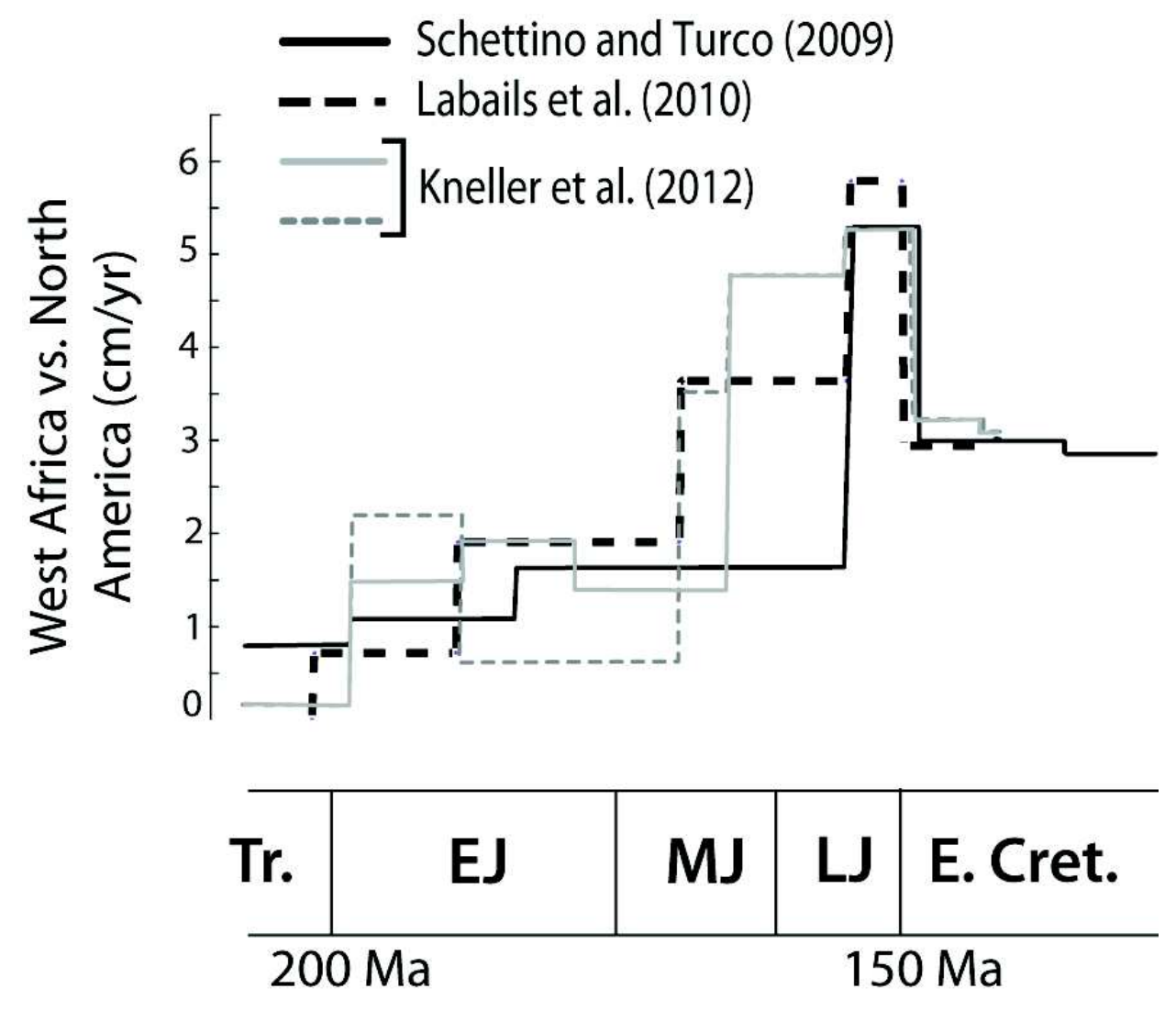

Figure 12

Nova Scotia (Grist \& Zentili, 2003)

Time (Ma)

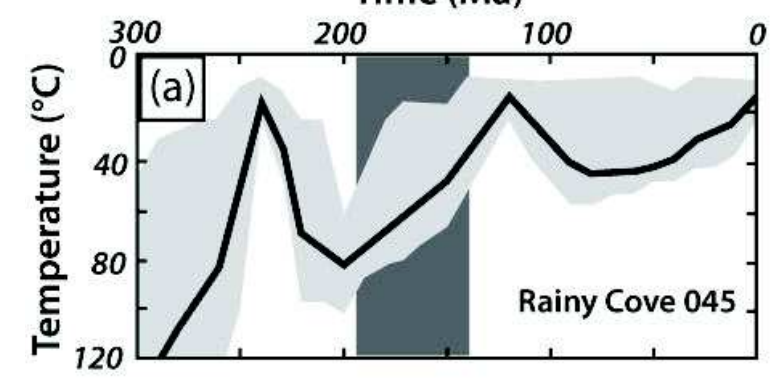

Southern Canadian Shield

(Lorencak et al., 2004)

Time (Ma)

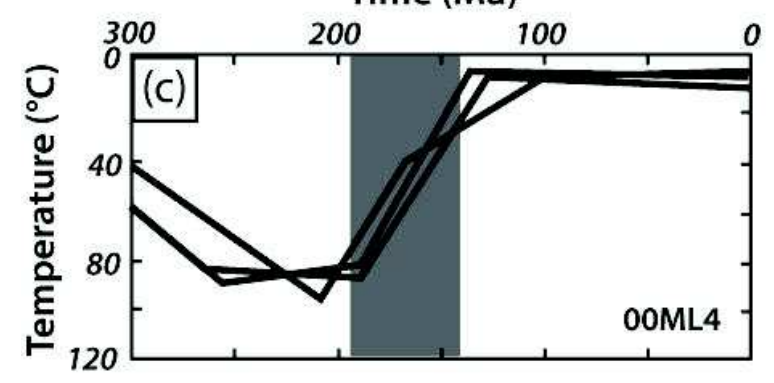

Michigan Basin (Wang et al., 1994)

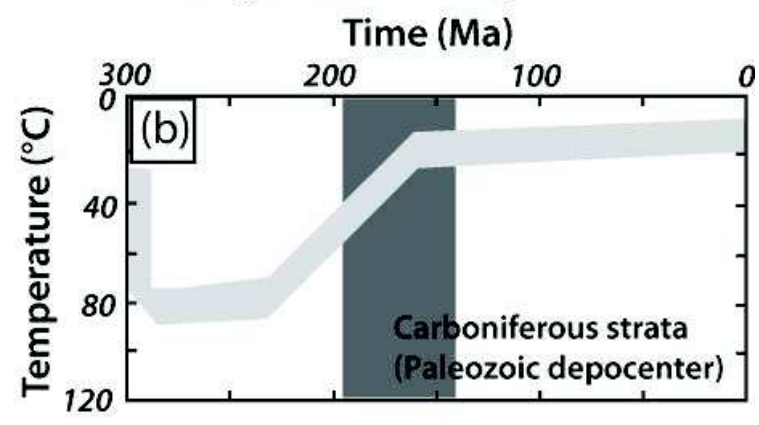

Northern Appalachian

(Taylor and Fitzgerald, 2011)

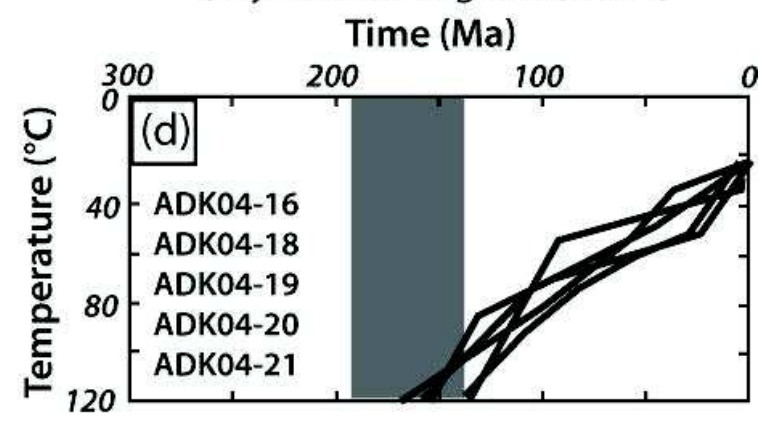




\section{Supplementary Data}

Text $\mathbf{S 1}$ - Modeling procedure for western RS samples

The thermal modeling for western RS samples is briefly recalled here. The reader is invited to read the extensive description given in Leprêtre et al. (2015).

The modeling of samples of the western RS was done through three steps, given the complexity of the dataset. A first step of inverse modeling was used as an exploratory tool to search the $(T, t)$ space. The stratigraphical constraint given by the unconformity of the Lower Cretaceous deposits and a data-dependent constraint implying samples to be at temperatures higher than $110^{\circ} \mathrm{C}$ before $200 \mathrm{Ma}$ were incorporated in the modeling to narrow the exploration of the $(T, t)$ space.

Second, representative thermal histories obtained in the first step were discriminated using the forward modeling. They implied further restrictions on the available $(T, t)$ paths that were incorporated as constraints in the third step of the modeling. The last step used inverse modeling with all determined constraints during the early steps to explore the degrees of freedom left to the model to better fit the data.

This three-step procedure led to four major constraints that we re-use here to model the AFT ages of AG167 and AG169 samples: (1) samples were at temperatures higher than $110^{\circ} \mathrm{C}$ before 200 Ma; (2) samples were near or at the surface during the Early Cretaceous; (3) a necessary reheating step occurred until the beginning of the Late Cretaceous; (4) a subsequent cooling up to $40^{\circ} \mathrm{C}$ by the end of the Late Cretaceous.

Text S2 - influence of apatite chemistry on the single-grain AHe ages scattering

To investigate the influence of the chemistry on the scattering of the single-grain AHe age, we used the mean thermal paths obtained through thermal modeling for all samples with AHe datasets. With forward modeling, we consider the whole range of Dpar and grain size of single grain within each sample. The grain size range is approximated through the equivalent sphere radius (Rs; see Table 2). The chemistry variations are taken into account through the $r m r 0$ factor, as defined by Ketcham et al. (2007). An empirical relationship links the Dpar and the rmro through the following equation:

$r m r 0=0.84 \times[(4.58-D p a r) / 2.98]^{0.21}$, the $r m r 0$ being used as the chemical determinant for the forward modeling with HeFTy for our tests.

We tested each final thermal path in forward modeling, varying the values of $r m r 0$ and Rs. For an eU range, we then reported the obtained AHe age-eU relationship for the four couple (rmro; Rs) tested (Fig. S17). One can see on figure S17 that generally, the single-grain AHe ages scattering can simply depend on these two parameters. Some out-of-trend replicates need others explanations, like the shape of broken apatite crystals (Brown et al., 2013) or contamination (Gautheron et al., 2012). 

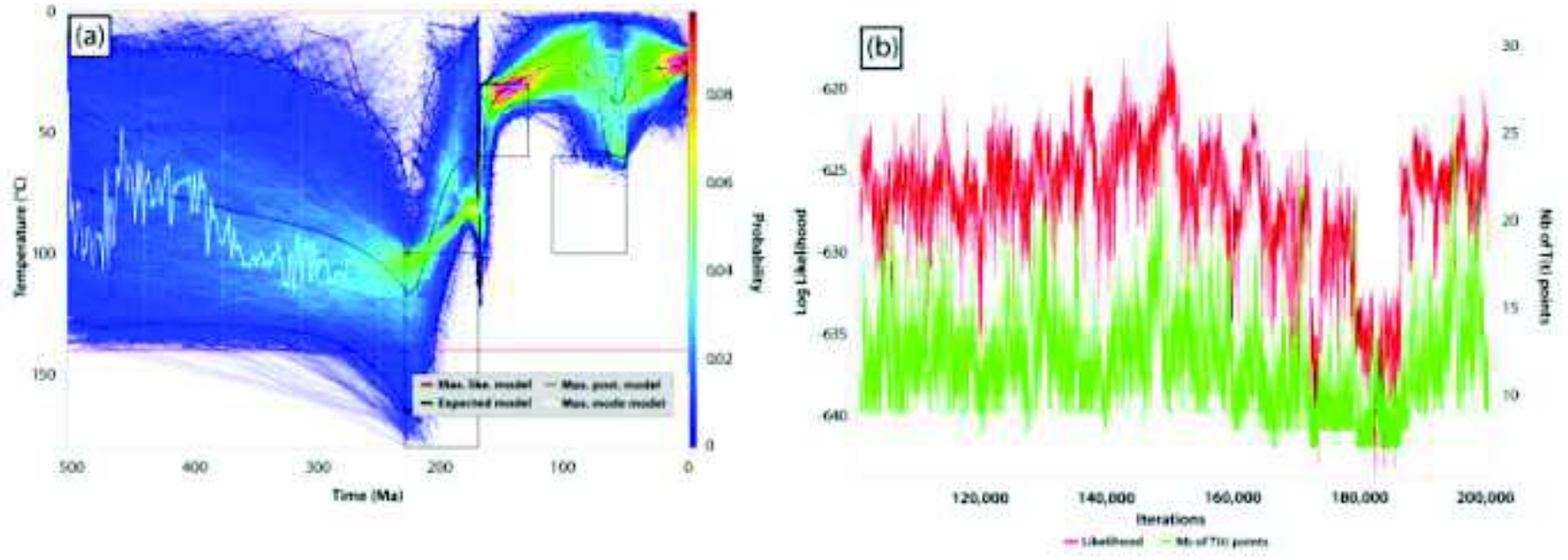

$4=6 \sin 19$

15 FIAOXZSP:1732SP : $161.7+5430$

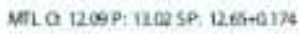

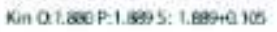
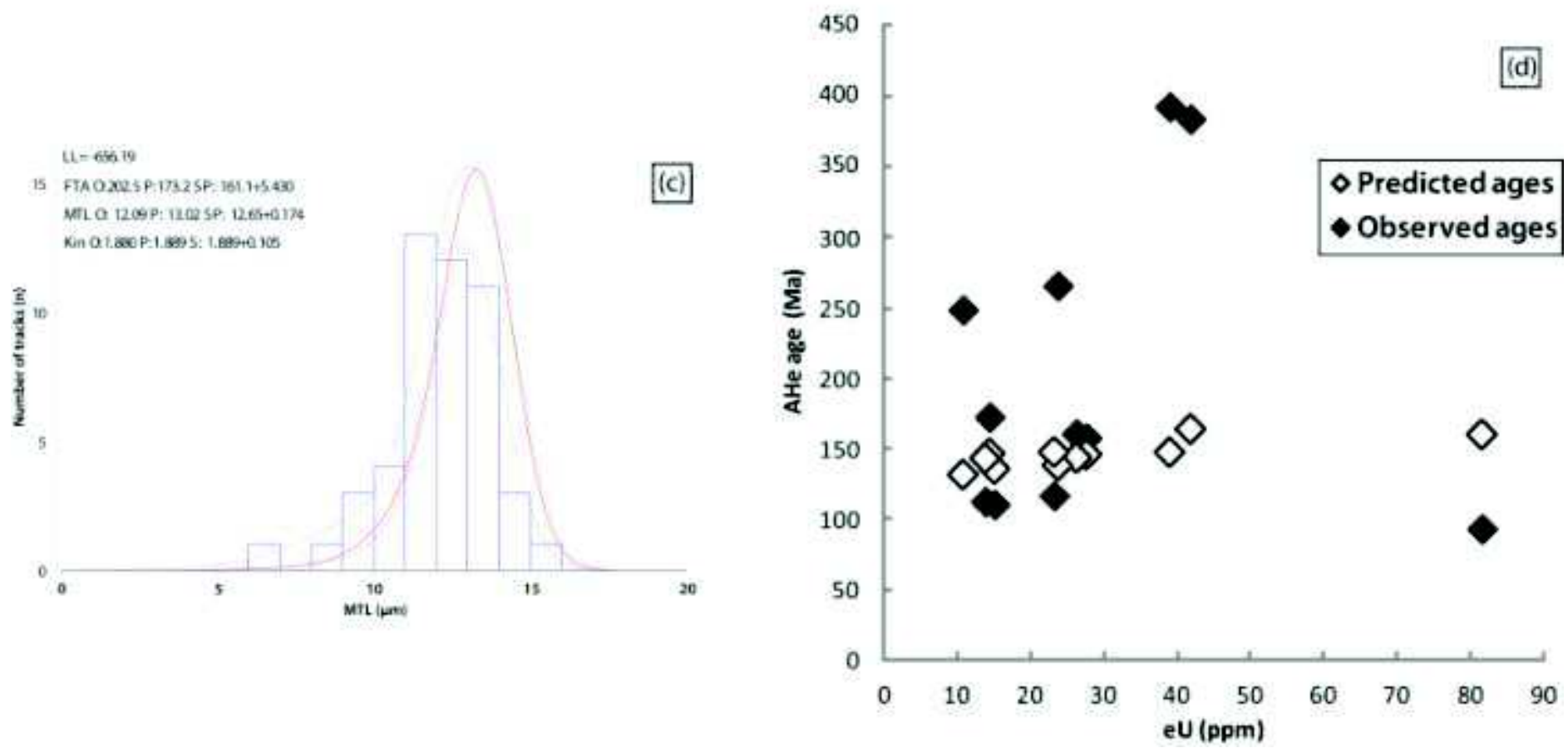

Figure S1: Thermal modeling of AL10 sample with all single-grain AHe ages. The figure must be compared with figure S12. It shows the instabilities produced by the use of anomalous replicates. . (a) Thermal history with different outputs (see details in Gallagher, 2012); (b) Evolution of the LL and the number of $T(t)$ points during the post-burn-in phase; (c) Predicted parameters for the expected model (black line in (a)). In red line is the predicted length distribution (superimposed on blue histogram in other samples). LL: LogLikelihood; FTA: fission track age; MTL: mean track length; Kin: Dpar; O: observed; P: predicted. 


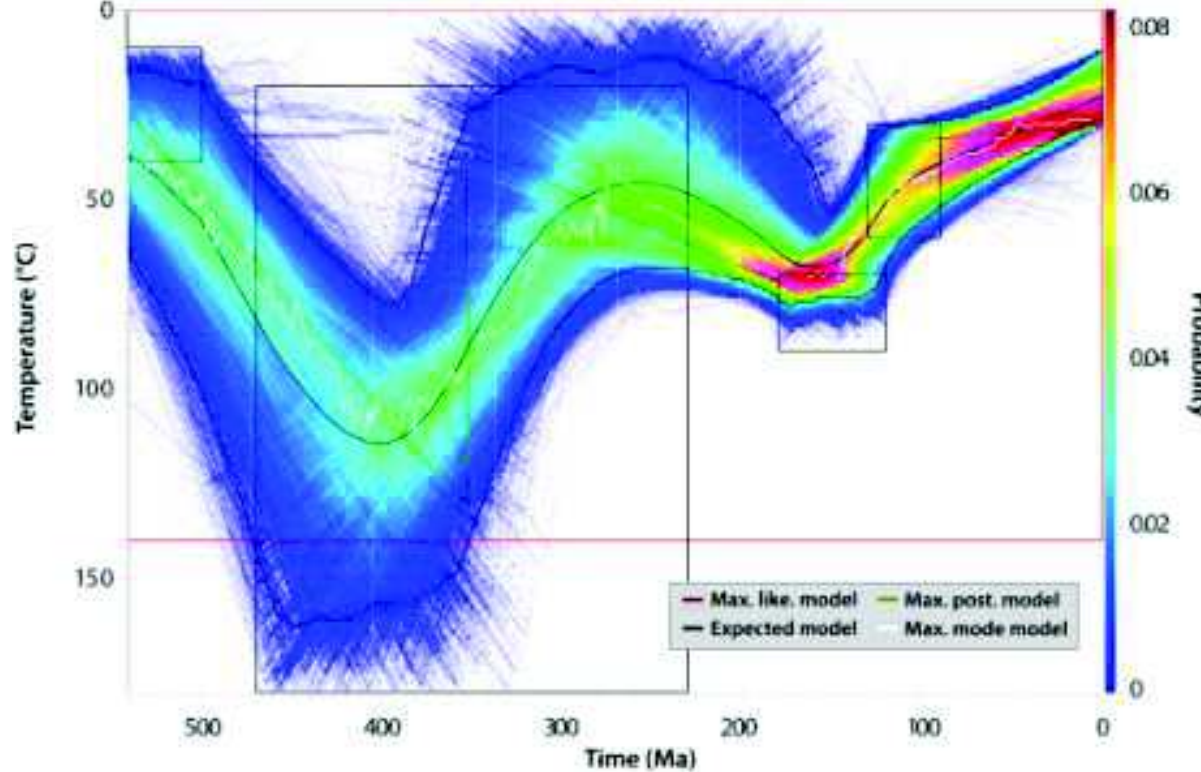

$\mathrm{Li}=-346,90$

FTA O.263.9P:268.3 SP: $2598+1473$

15 MTL Q 1202P: 1211 SP: $11.96+0.177$ Kin 0:2009P:2095 S: 2095:0.136

है

5

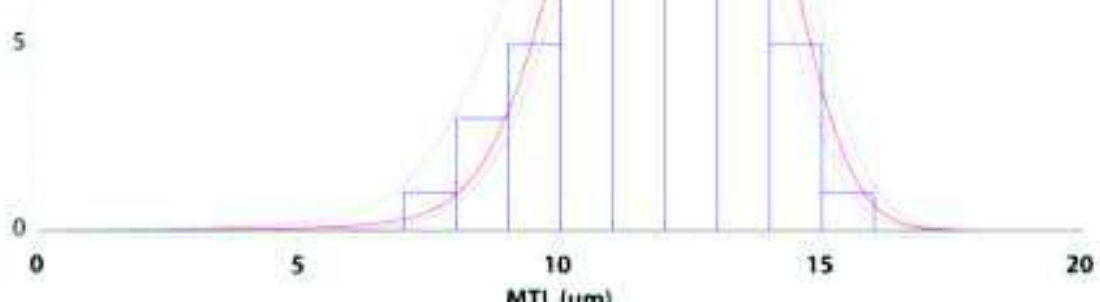

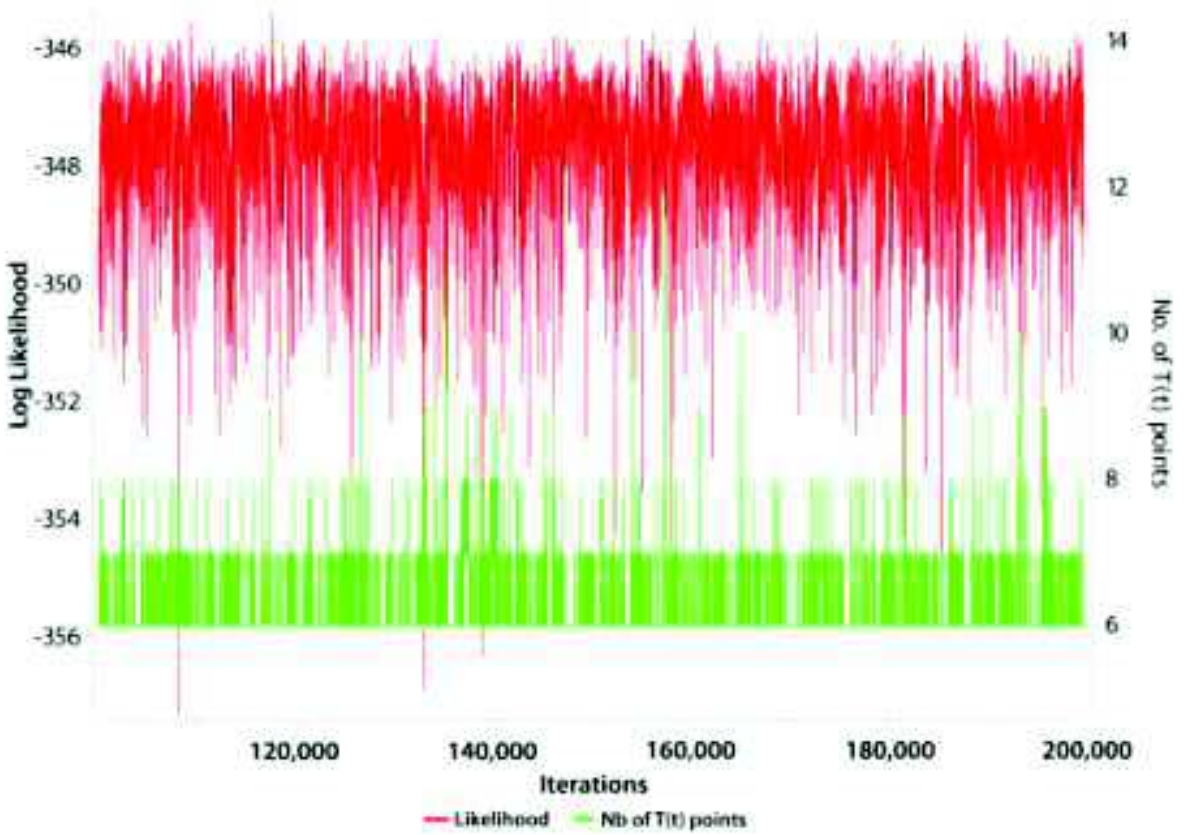

Figure S2: Thermal modeling of $\mathrm{CH} 2$ sample. (a) Thermal history with

different outputs (see details in Gallagher, 2012); (b) Evolution of the LL and the number of $\mathrm{T}(\mathrm{t})$ points during the post-burn-in phase; (c) Predicted parameters for the expected model (black line in (a)). In red line is the predicted length distribution (superimposed on blue histogram in other samples). LL: LogLikelihood; FTA: fission track age; MTL: mean track length; Kin: Dpar; O: observed; P: predicted; 


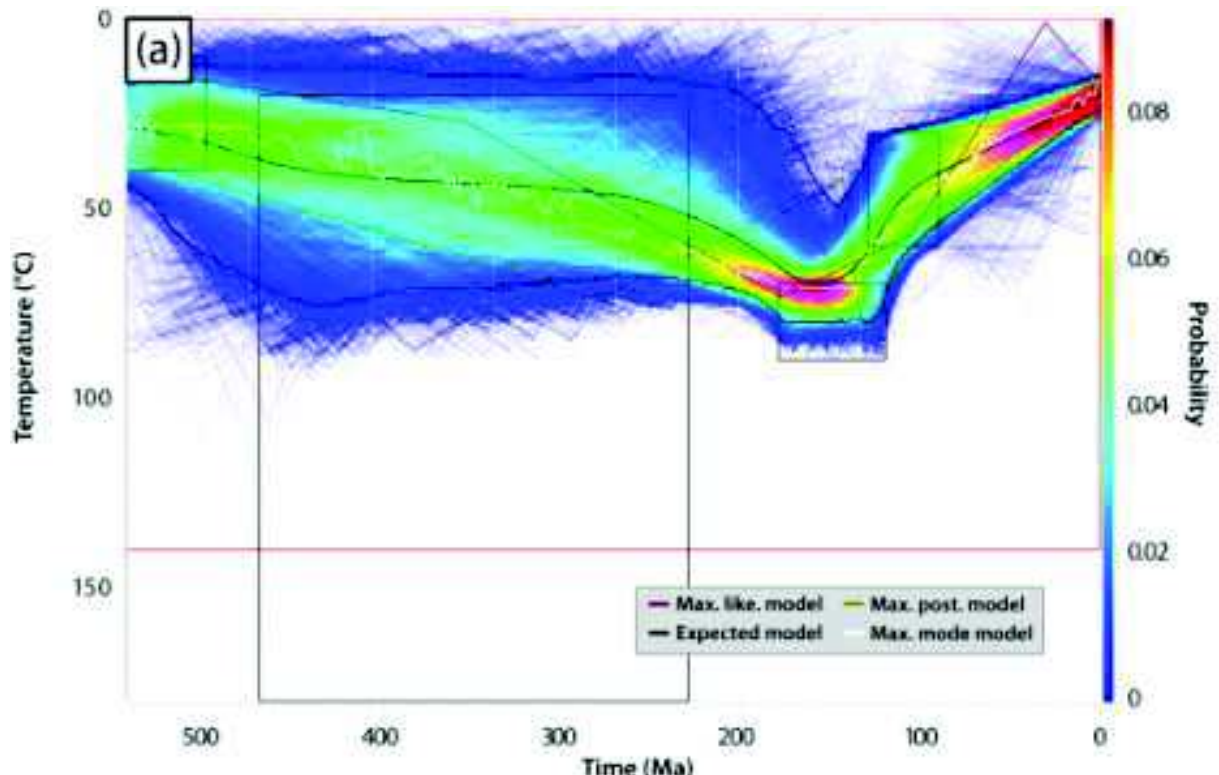

${ }_{6} \mathrm{LL}=-1747$

FTA O.355.1P:3806 SP: $351.3+16.92$

5 MIL O 11.23p: $11.605 P=11.28+0.183$ Kin 01980:19875:1087+0109

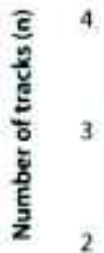

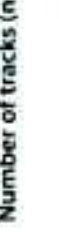

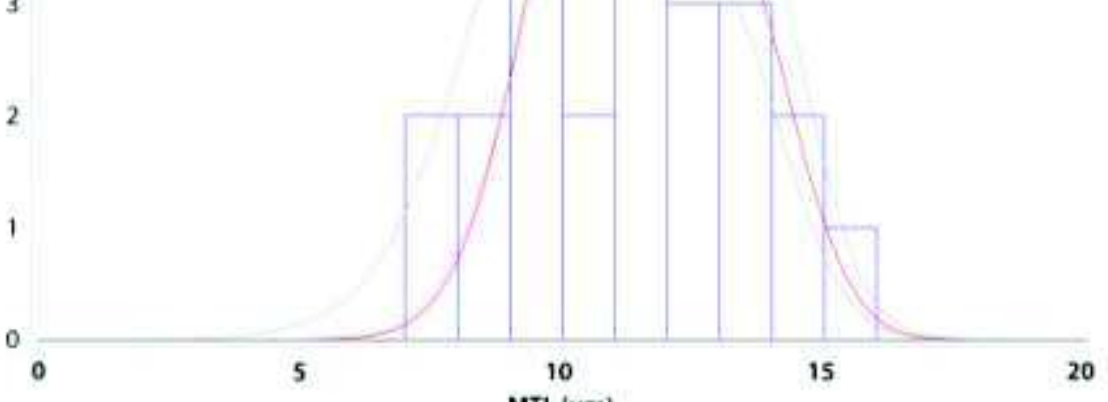

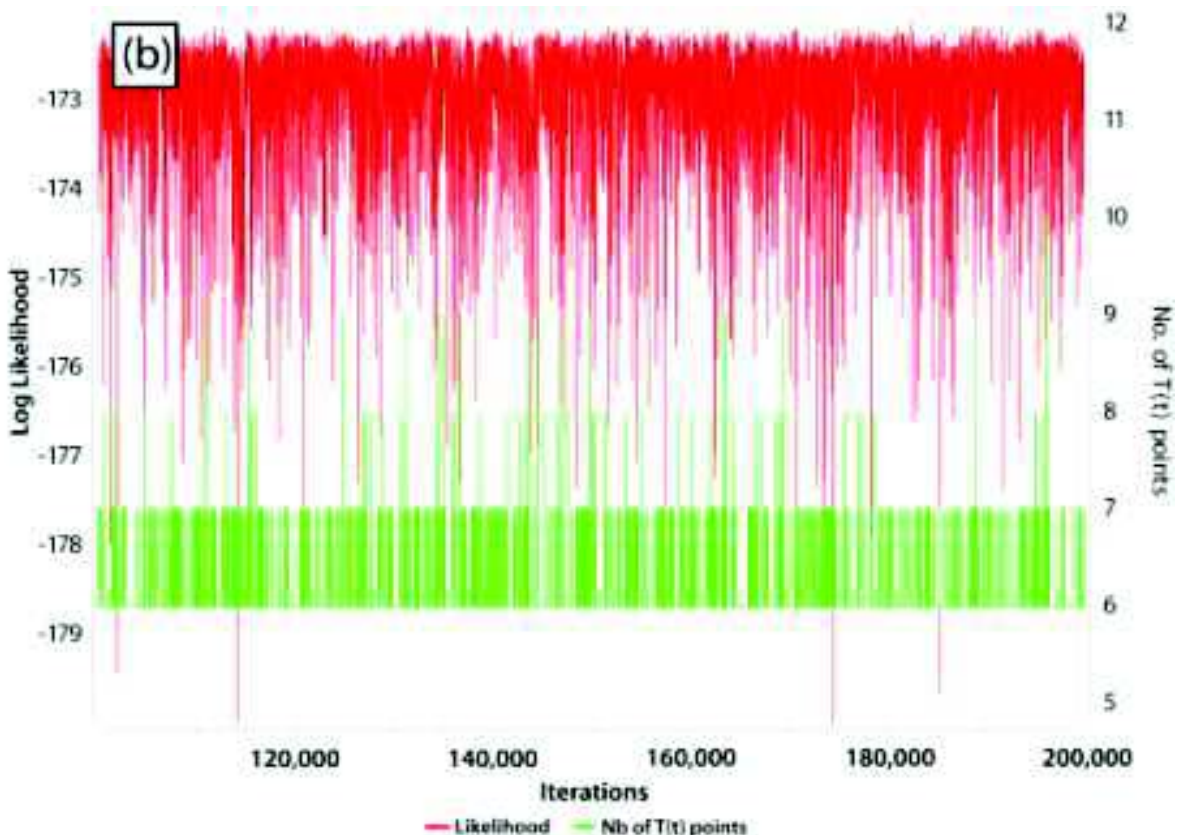

(c)
Figure S3: Inverse modeling for samples DEG6. Same legend as in figure $\mathrm{S} 2$. 

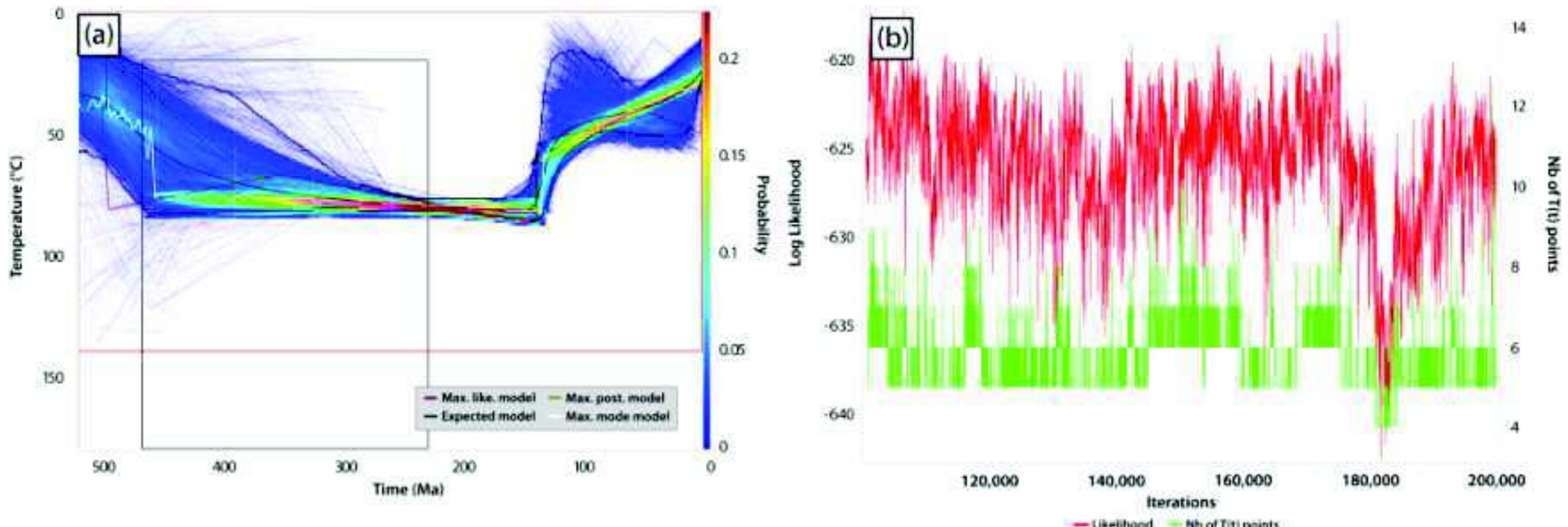

$U=-637.78$
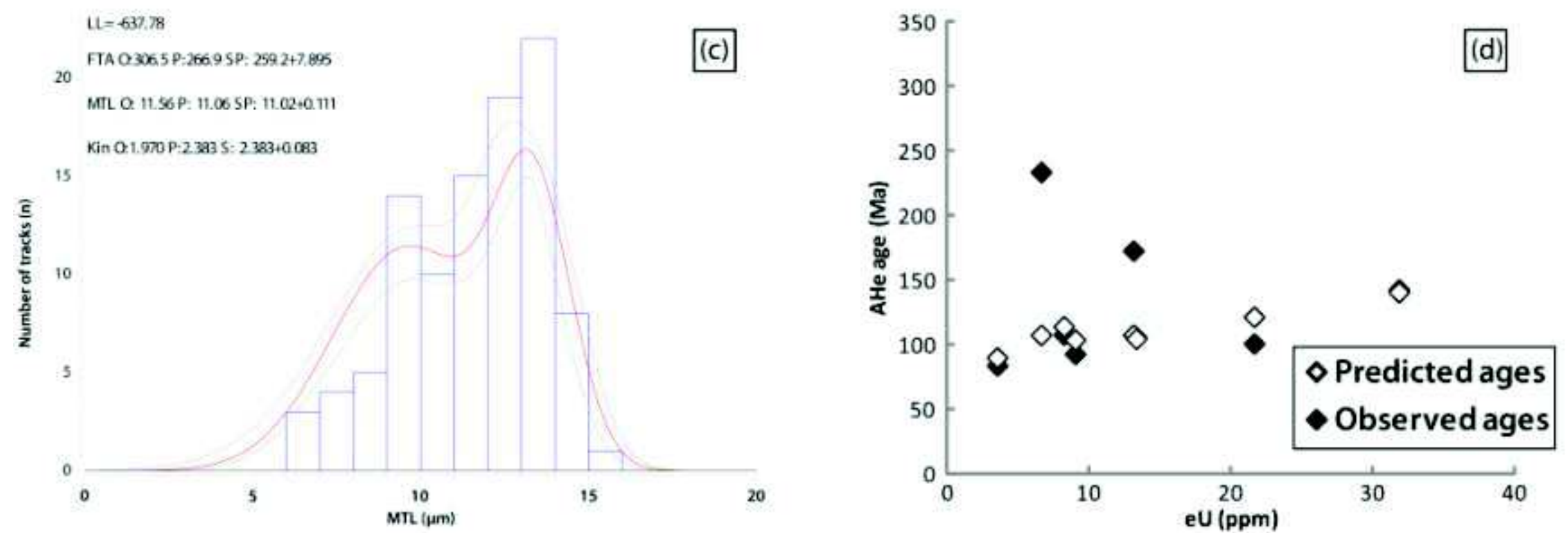

Figure S4: Inverse modeling for sample CH1. Same legend as in figure S2. (d) observed vs. predicted AHe ages. 

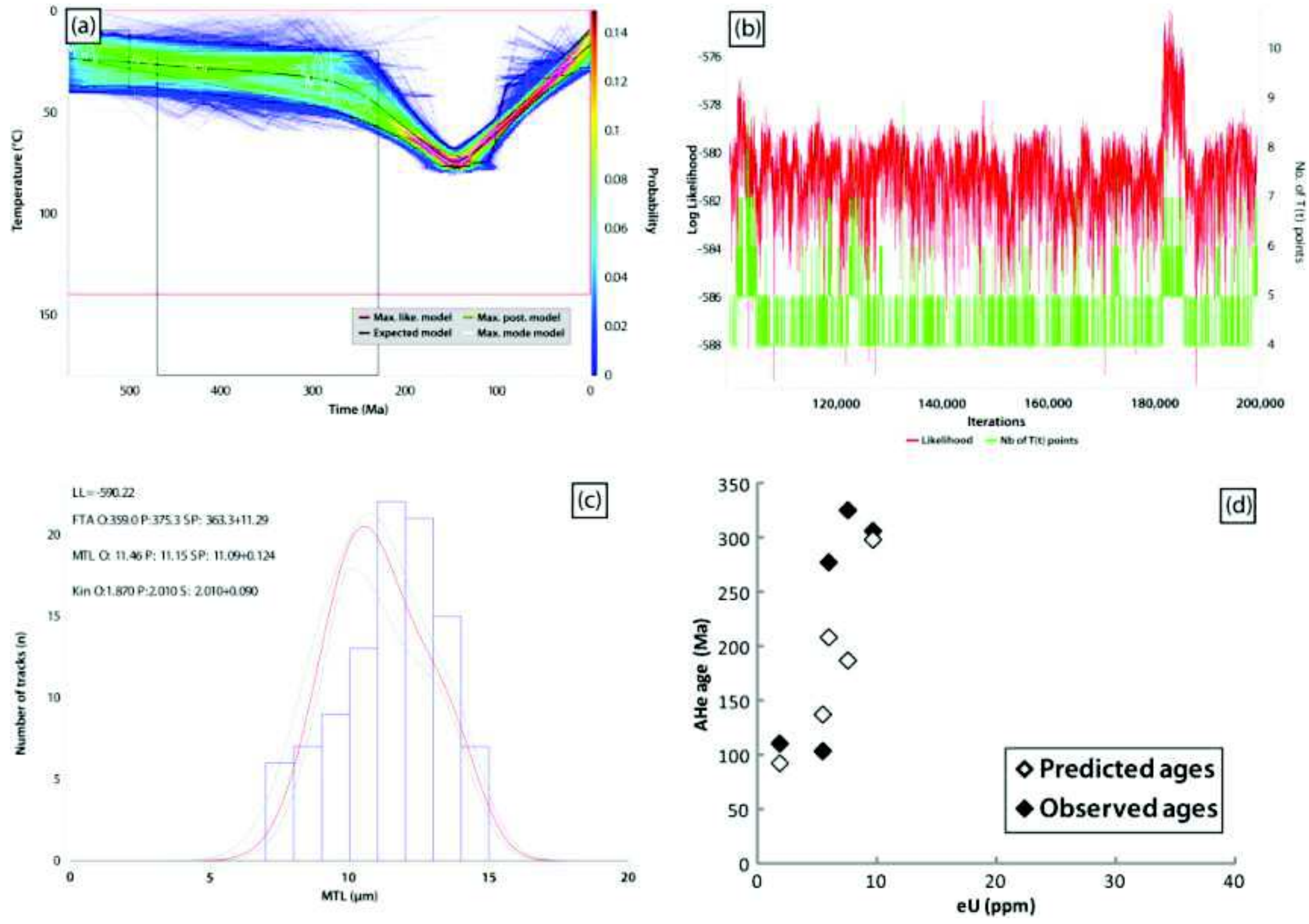

Figure S5: Inverse modeling for sample CH3. Same legend as in figures S2 and S4. 

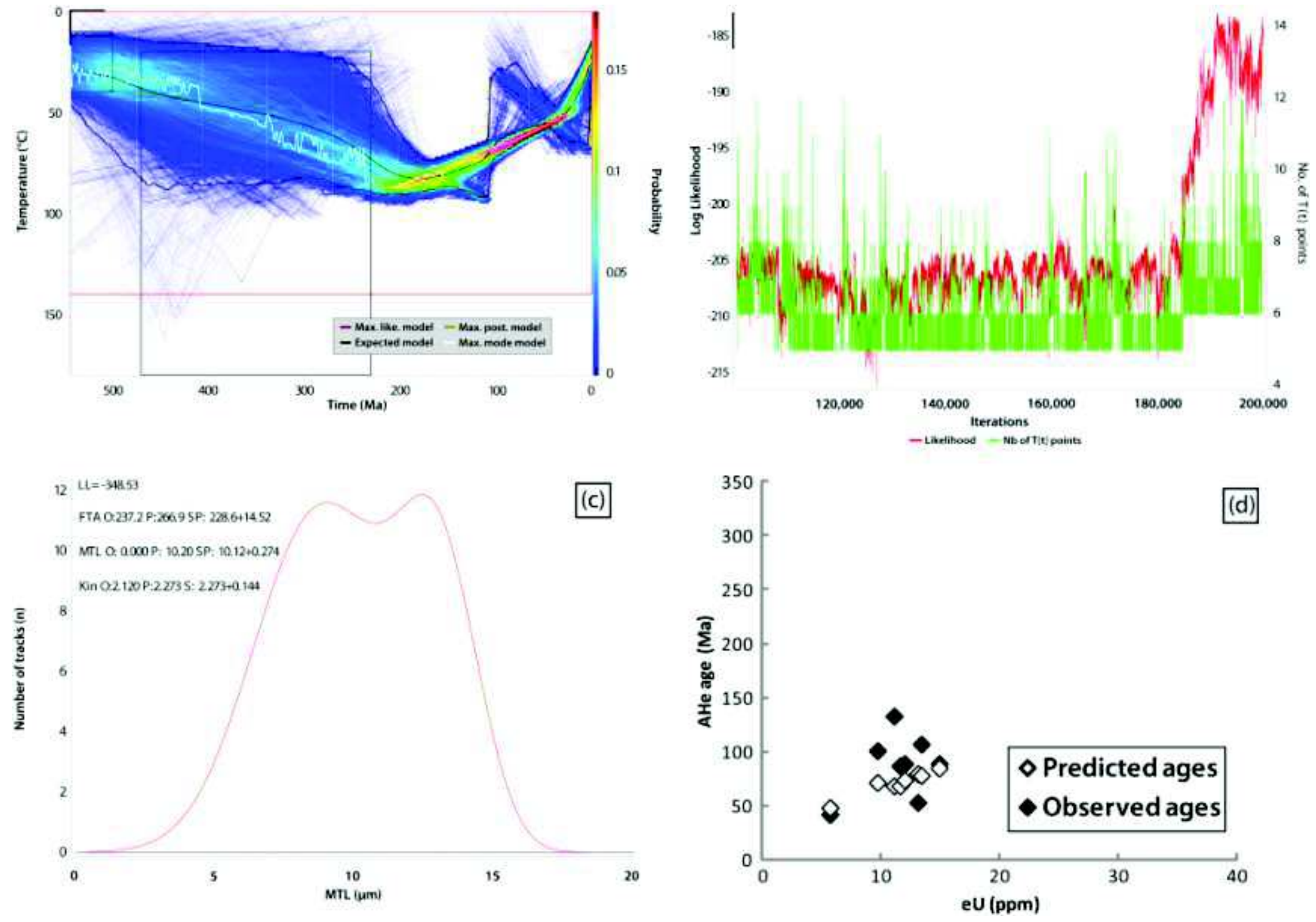

Figure S6: Inverse modeling for sample TL3. Same legend as in figures S2 and S4. 

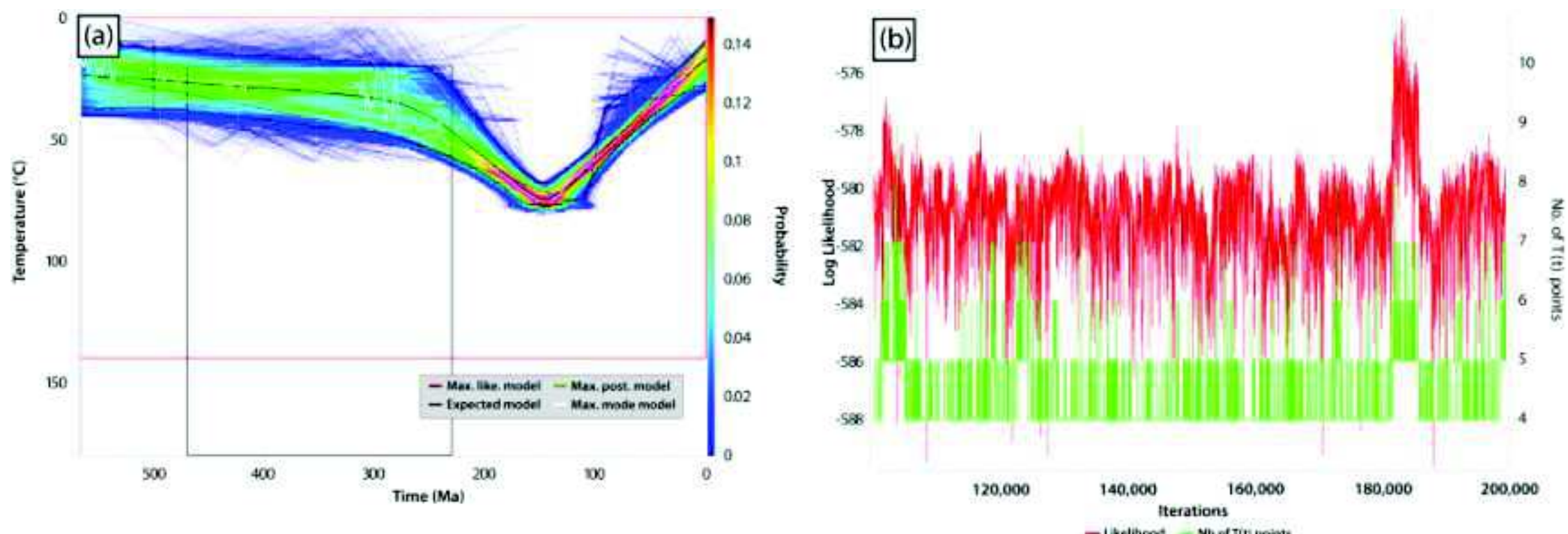

180,000

200.000 - Likelihoos - Nit af Tiv points
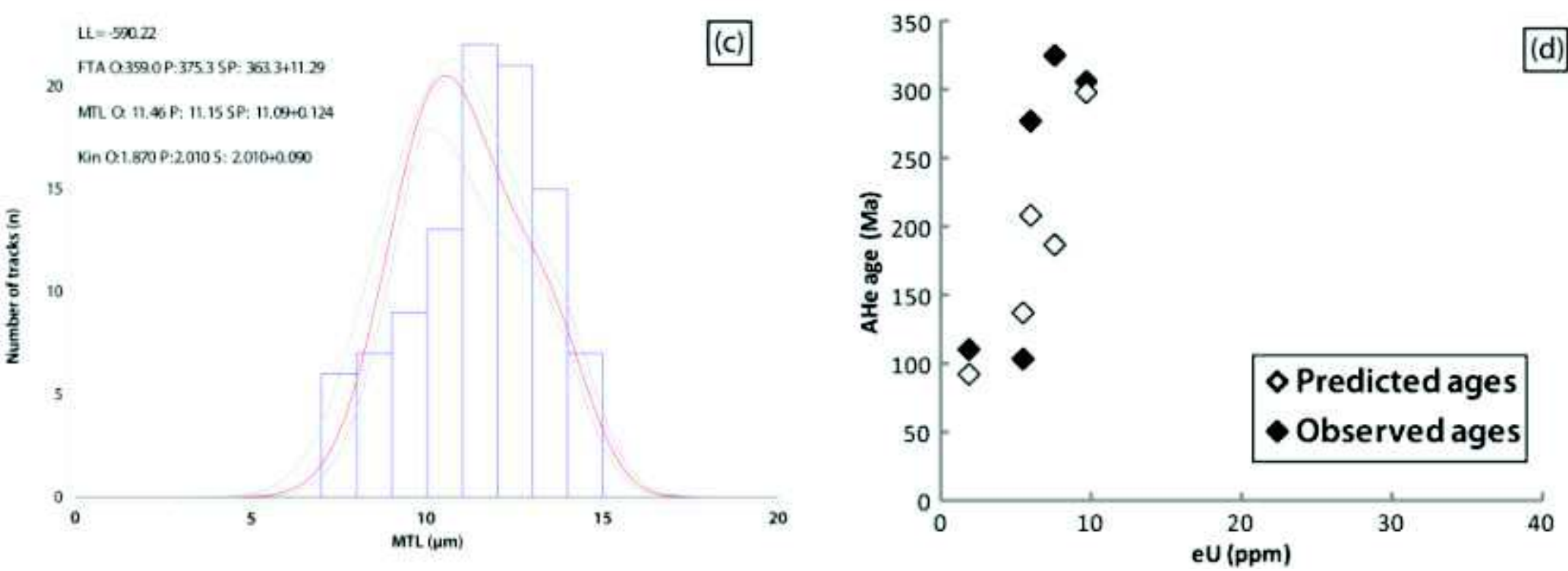

Figure S7: Inverse modeling for sample GH3. Same legend as in figures S2 and S4. 


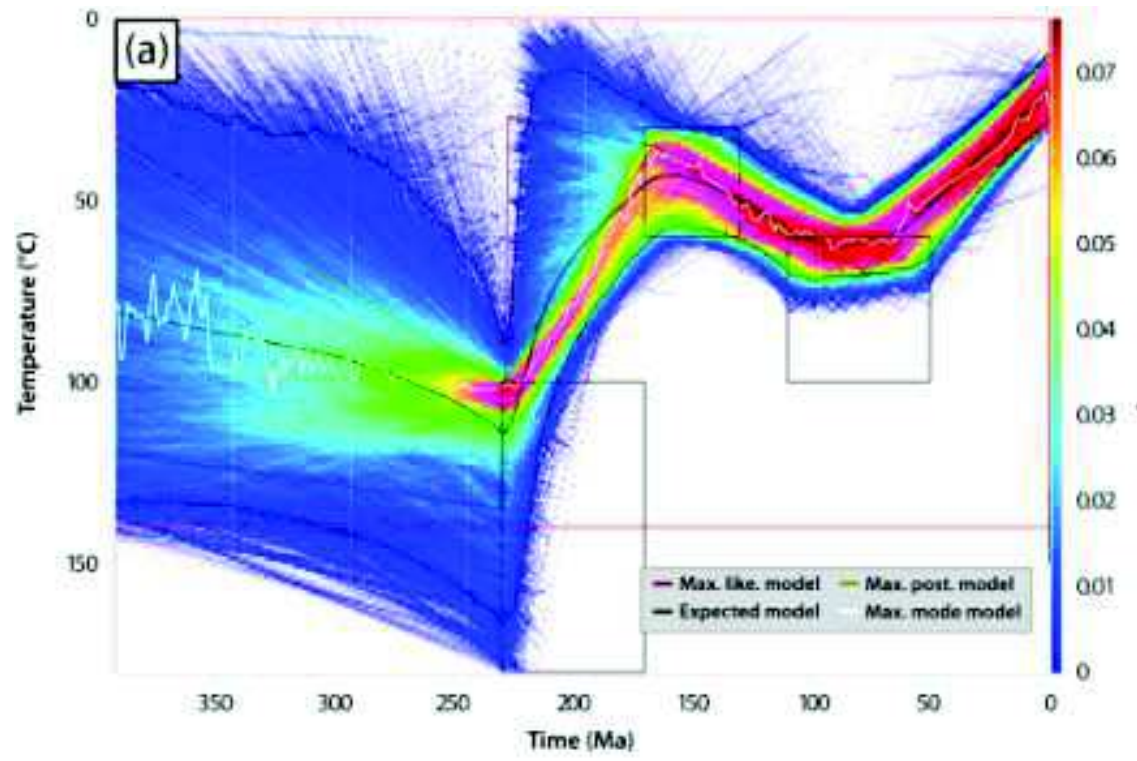

LI- -271.12

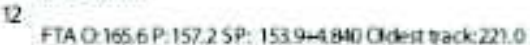

NLL O I1 39P: 11.735P: 117ro.179

Kin 016028.1.4015: 1601+019?

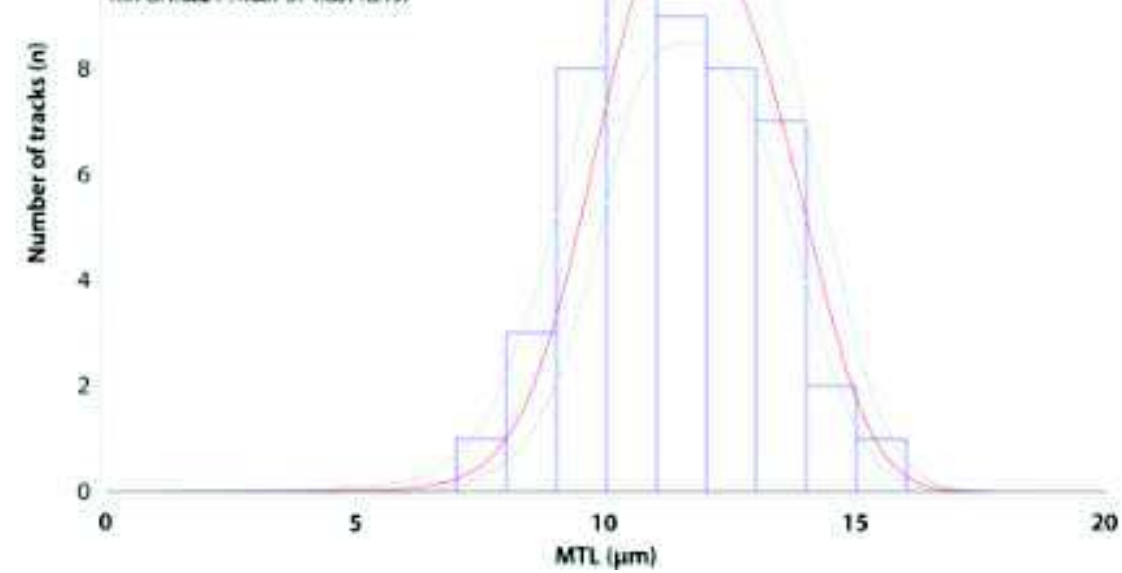

(c)

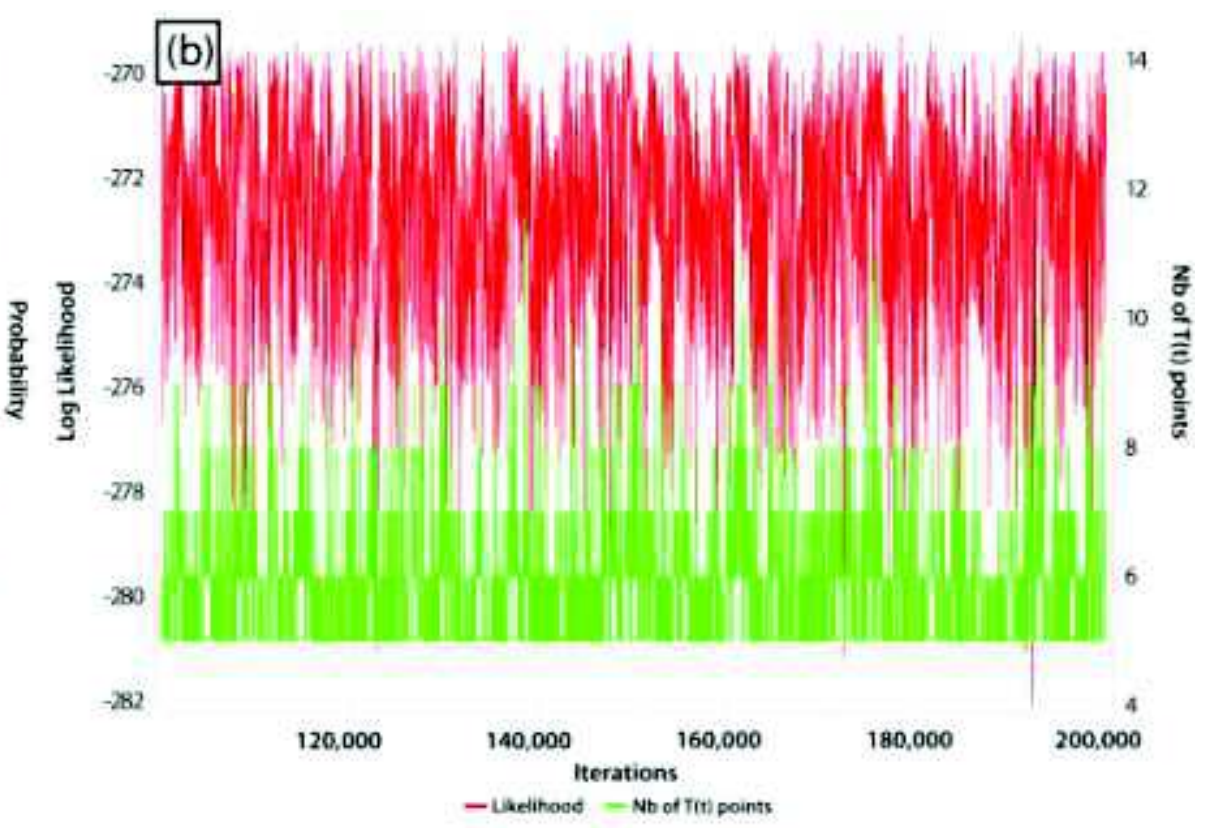

Figure S8: Inverse modeling for sample YT7. Same legend as in figure S2. 


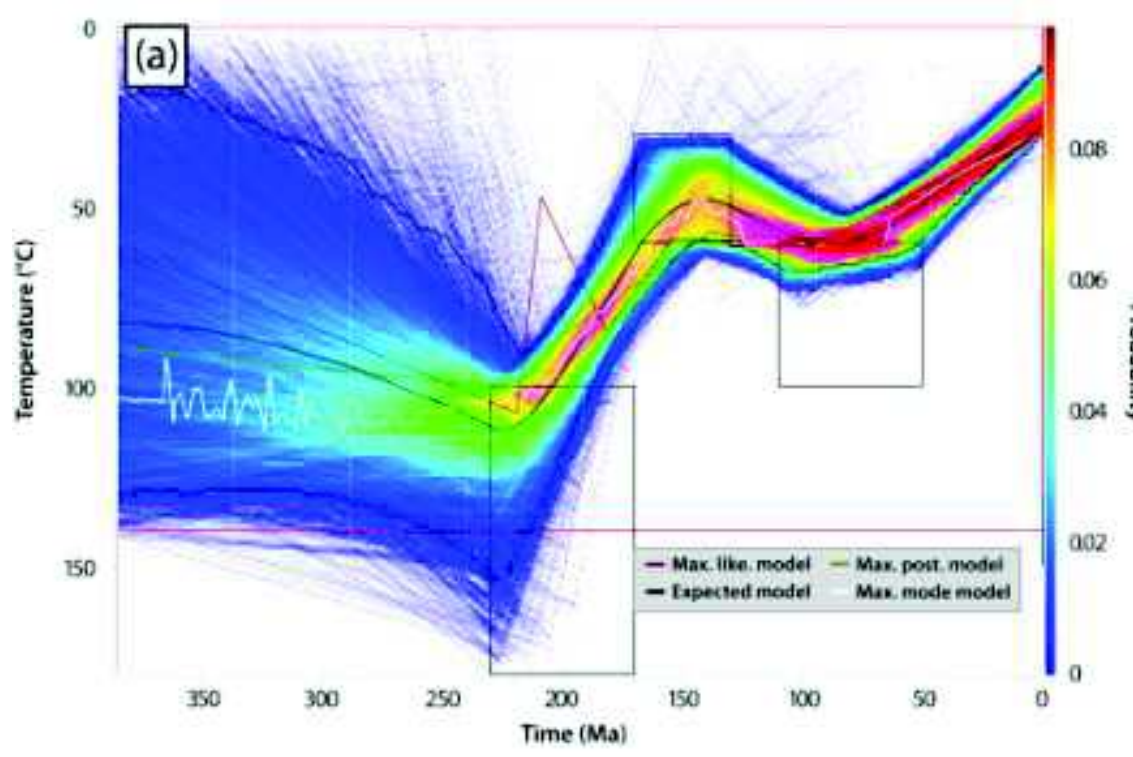

$$
\mathrm{LL}=-485.90
$$

30 FTA 0.1502 P: 147.45P: $146.4+5.428$ ${ }_{25}$ MTL O 11.85P: 1206 SP: $1200+0.139$ Kin $0,1.760 \cdot 1.7595 \cdot 1,759+0.9$

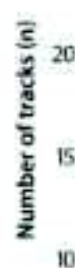

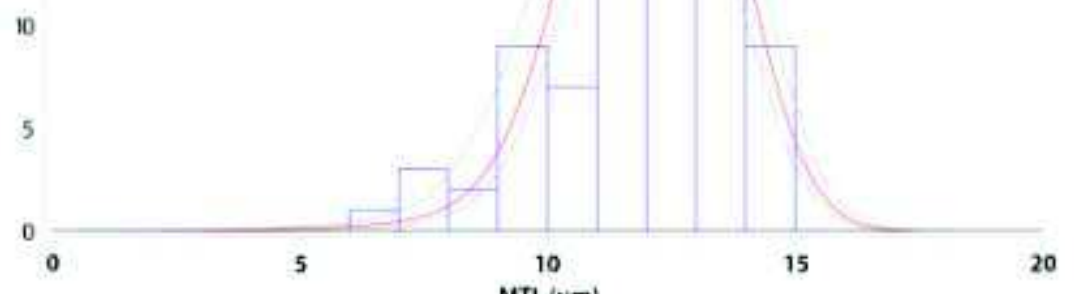

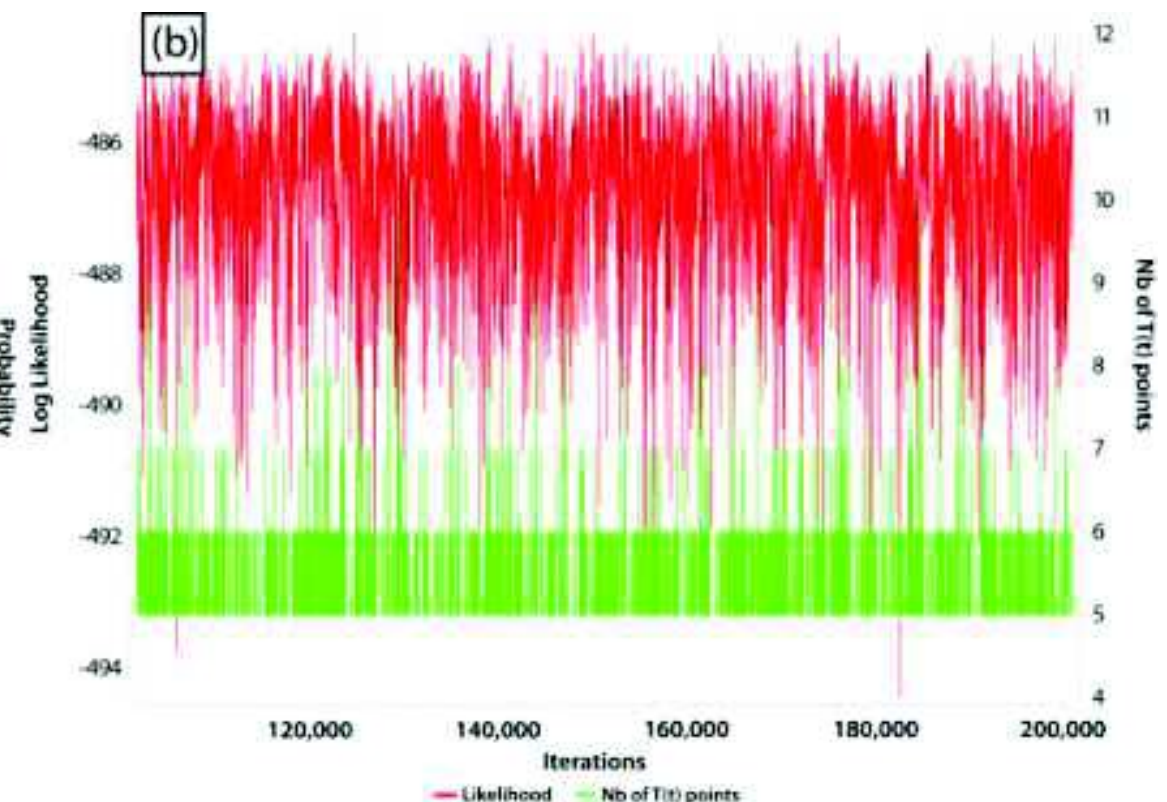

(c)

Figure S9: Inverse modeling for sample TGH3111B. Same legend as in figure S2. 


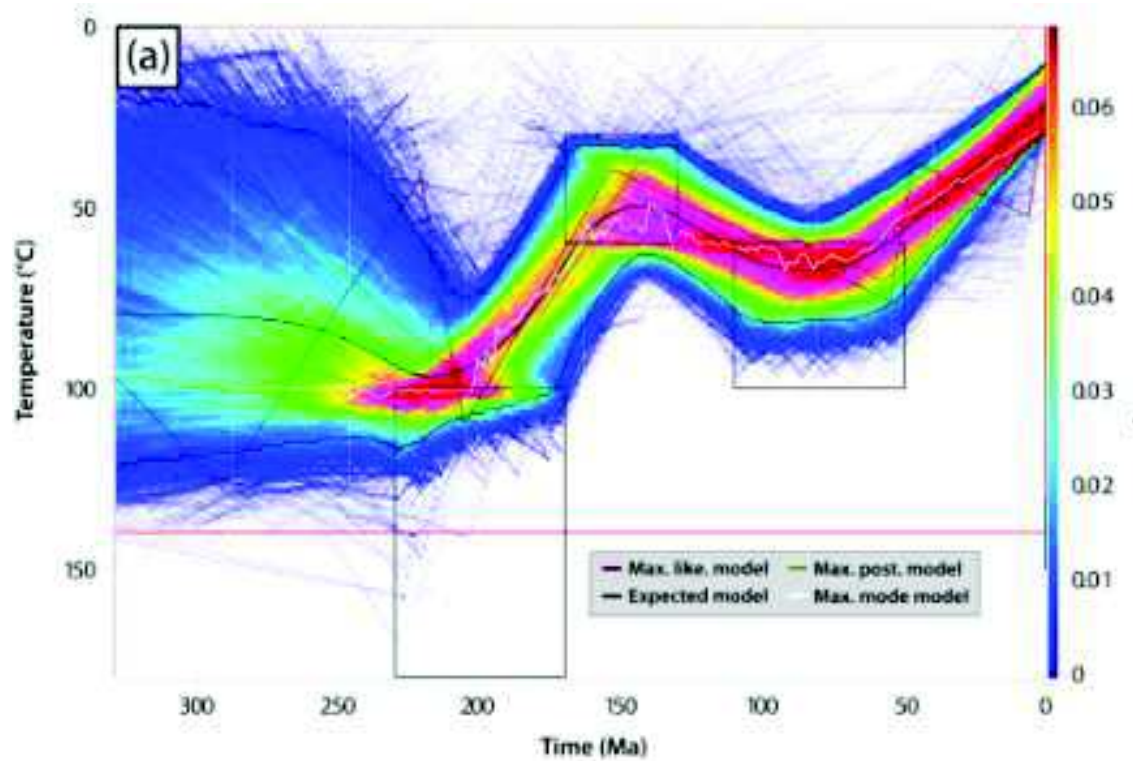

$L=216.80$

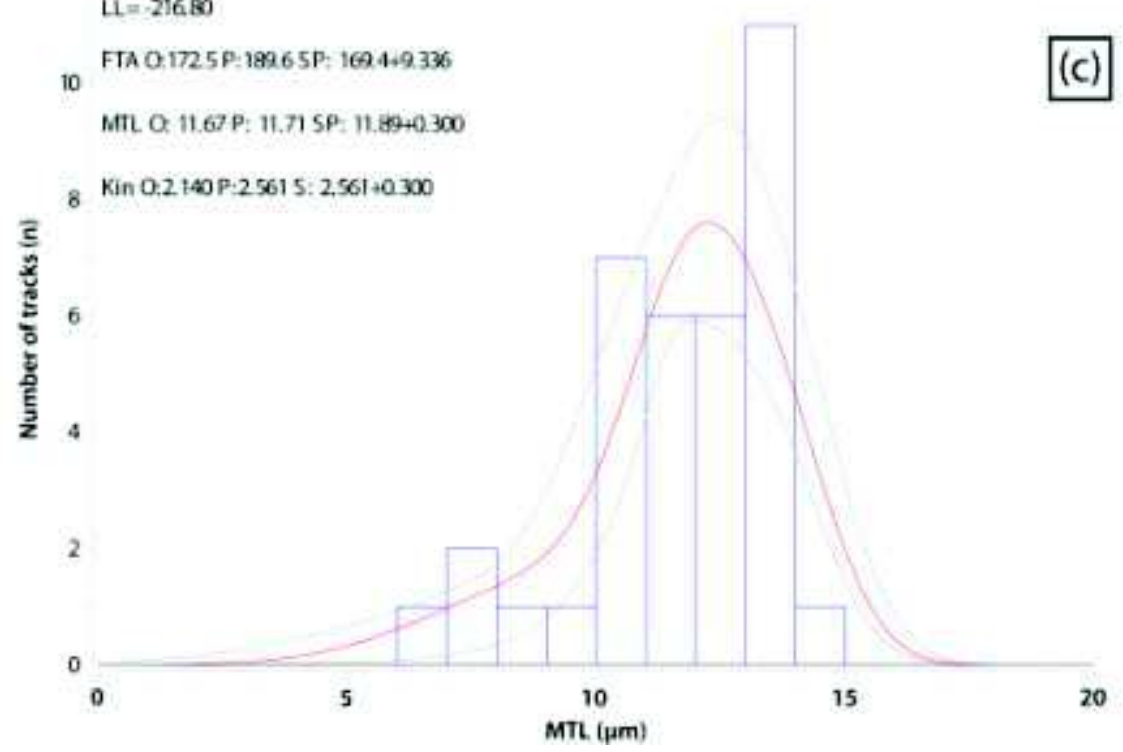

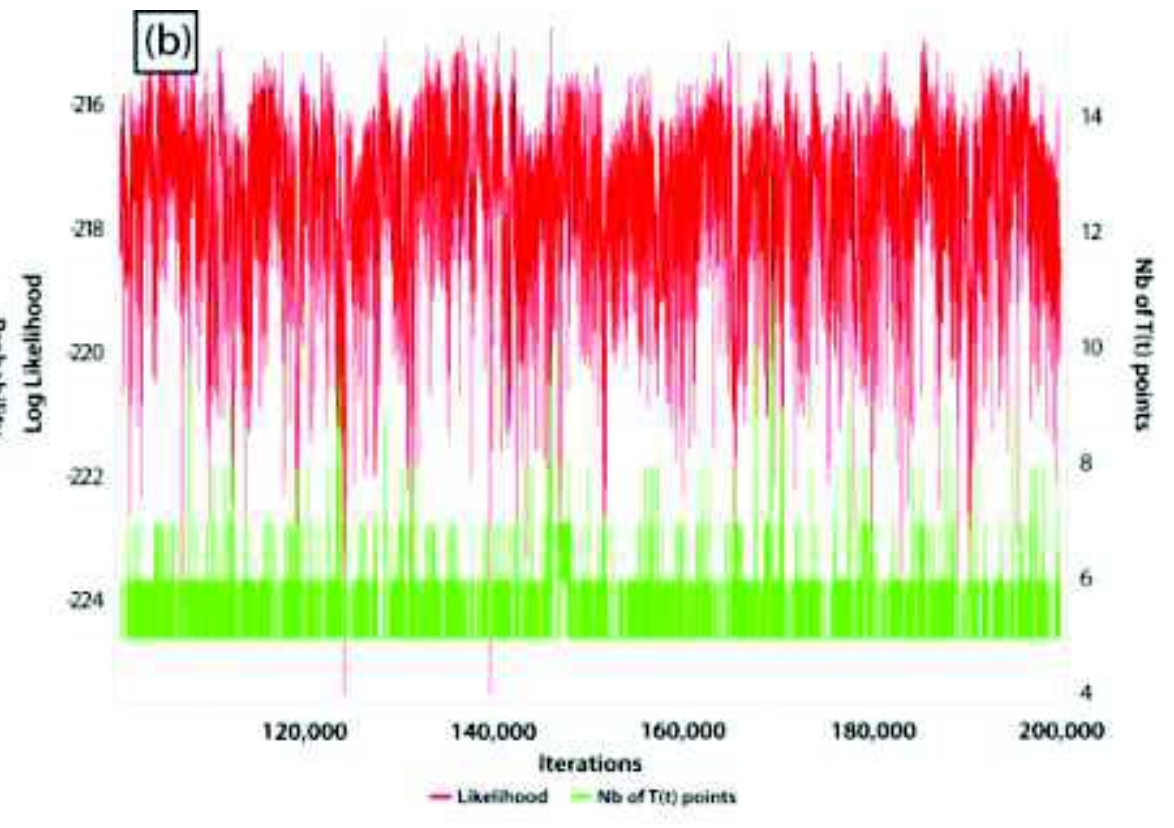

c)

Figure S10: Inverse modeling for sample TEN4065. Same legend as in figure $\mathbf{S 2}$ 


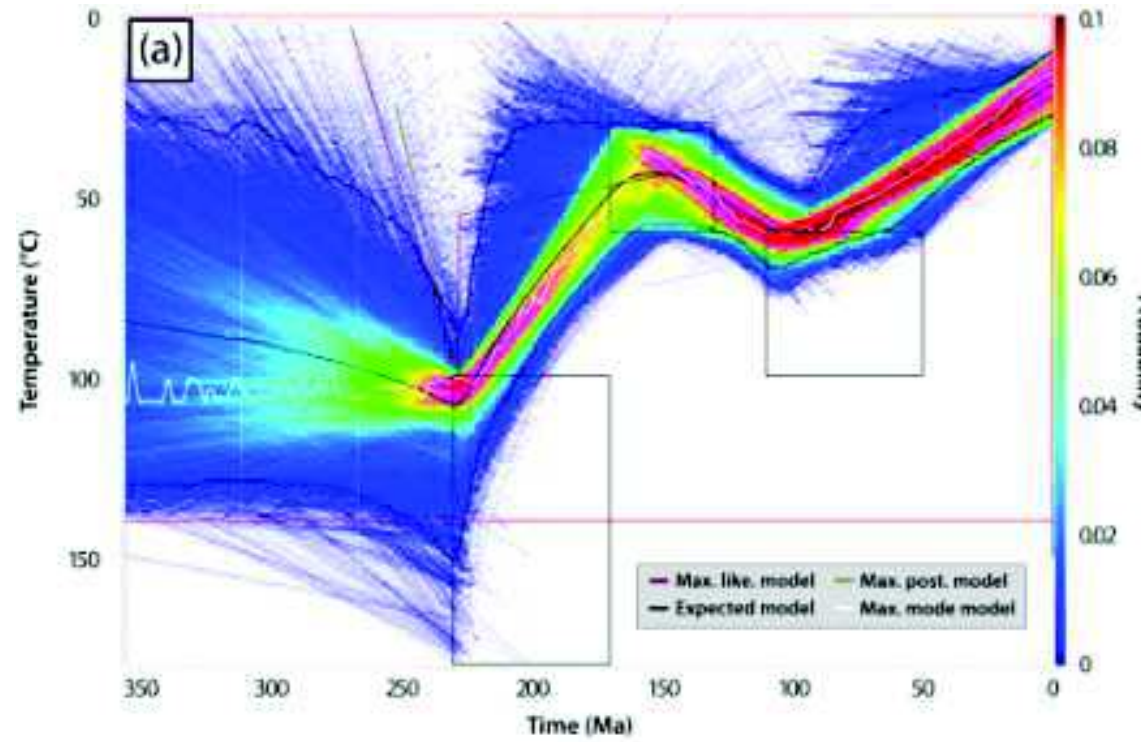

$1=5304$

30 FTAQ1984P:10045P: 16C 1+5.06

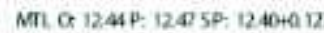

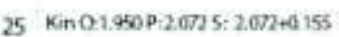
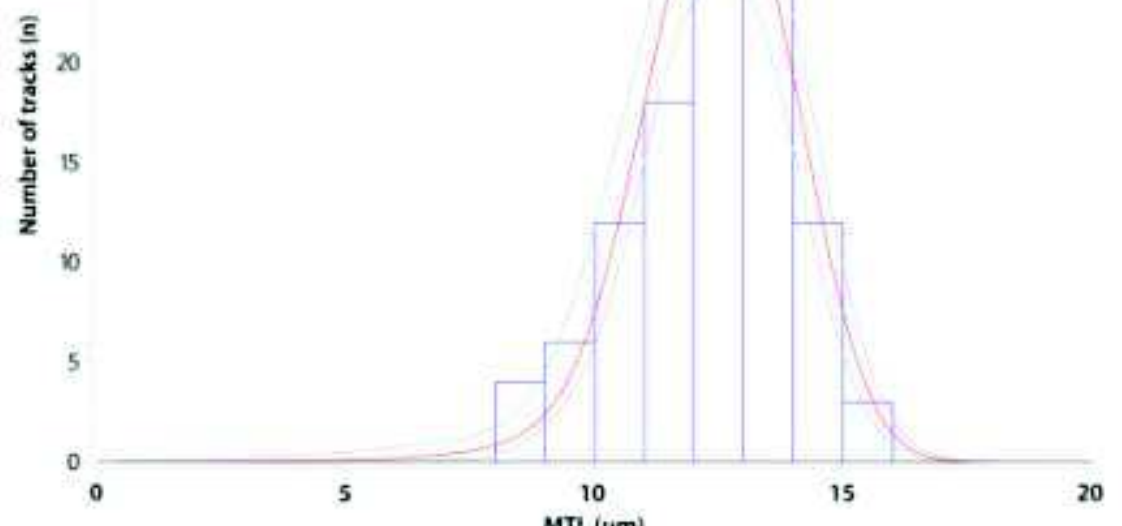

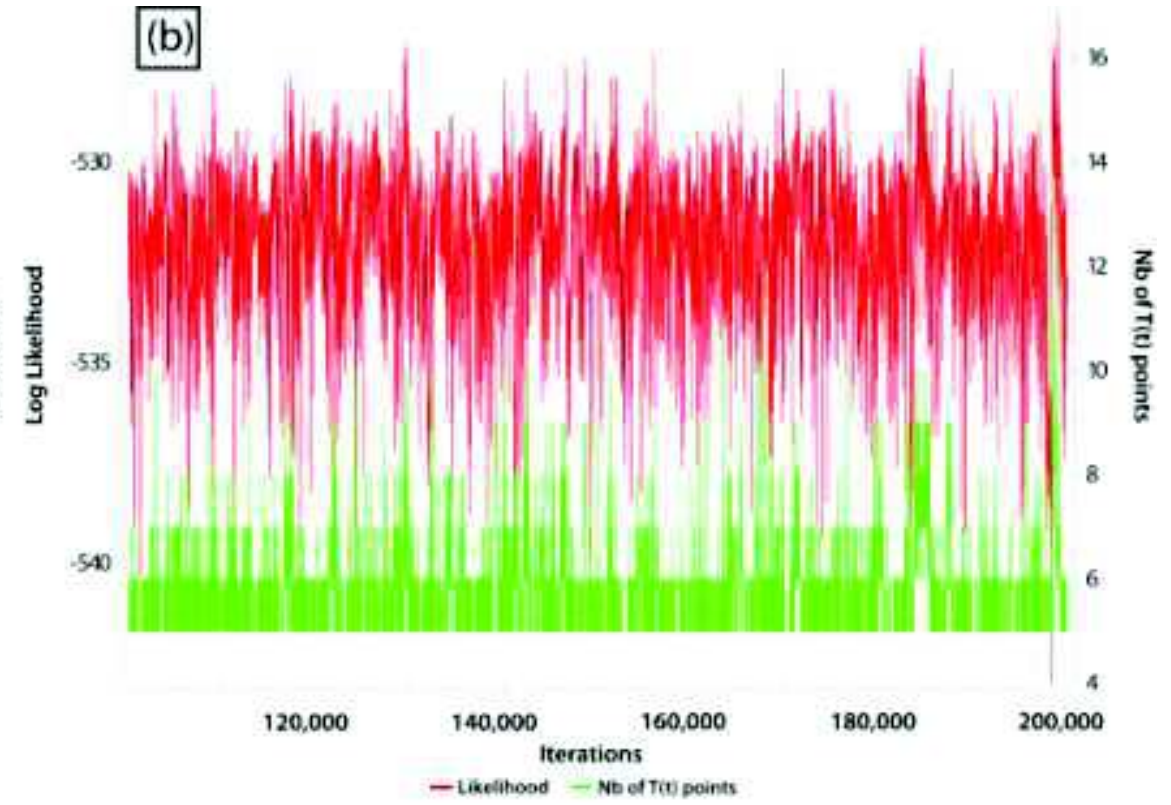

(c)
Figure S11: Inverse modeling for sample TGH4072A. Same legend as in figure $\mathrm{S} 2$ 

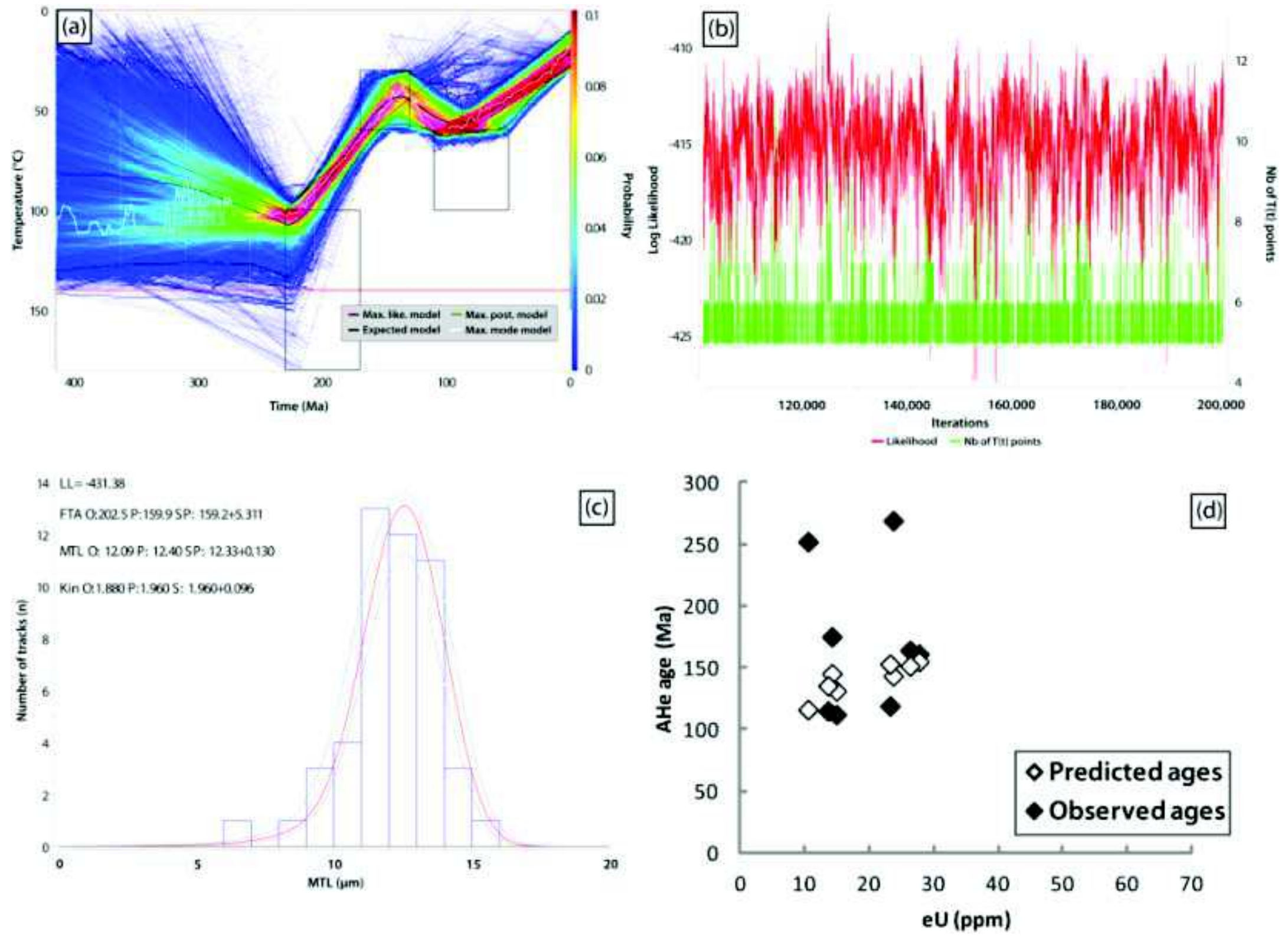

Figure S12: Inverse modeling for sample AL10. Same legend as in figures S2 and S4. 

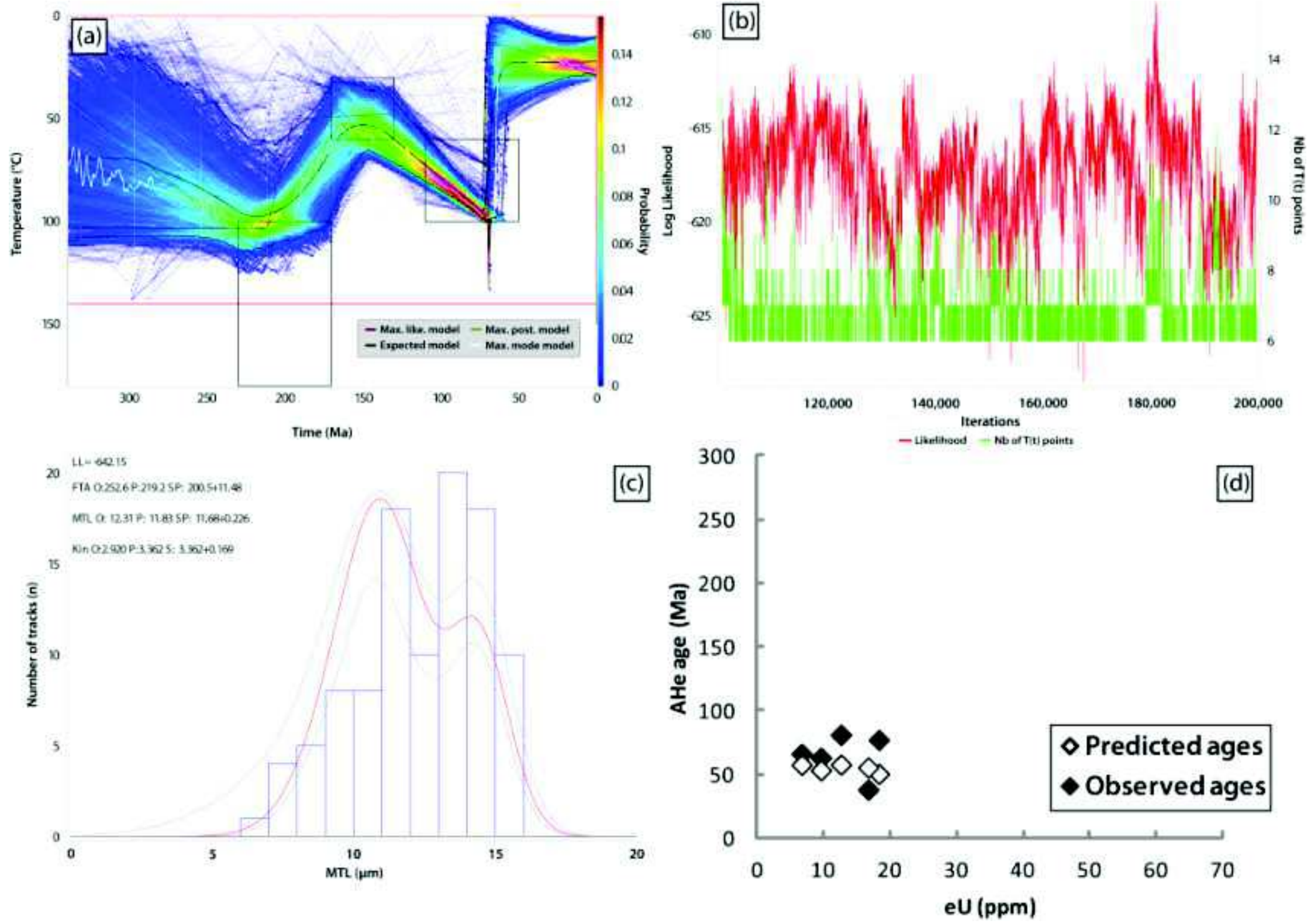

Figure S13: Inverse modeling for sample TEN1153. Same legend as in figures S2 and S4. 

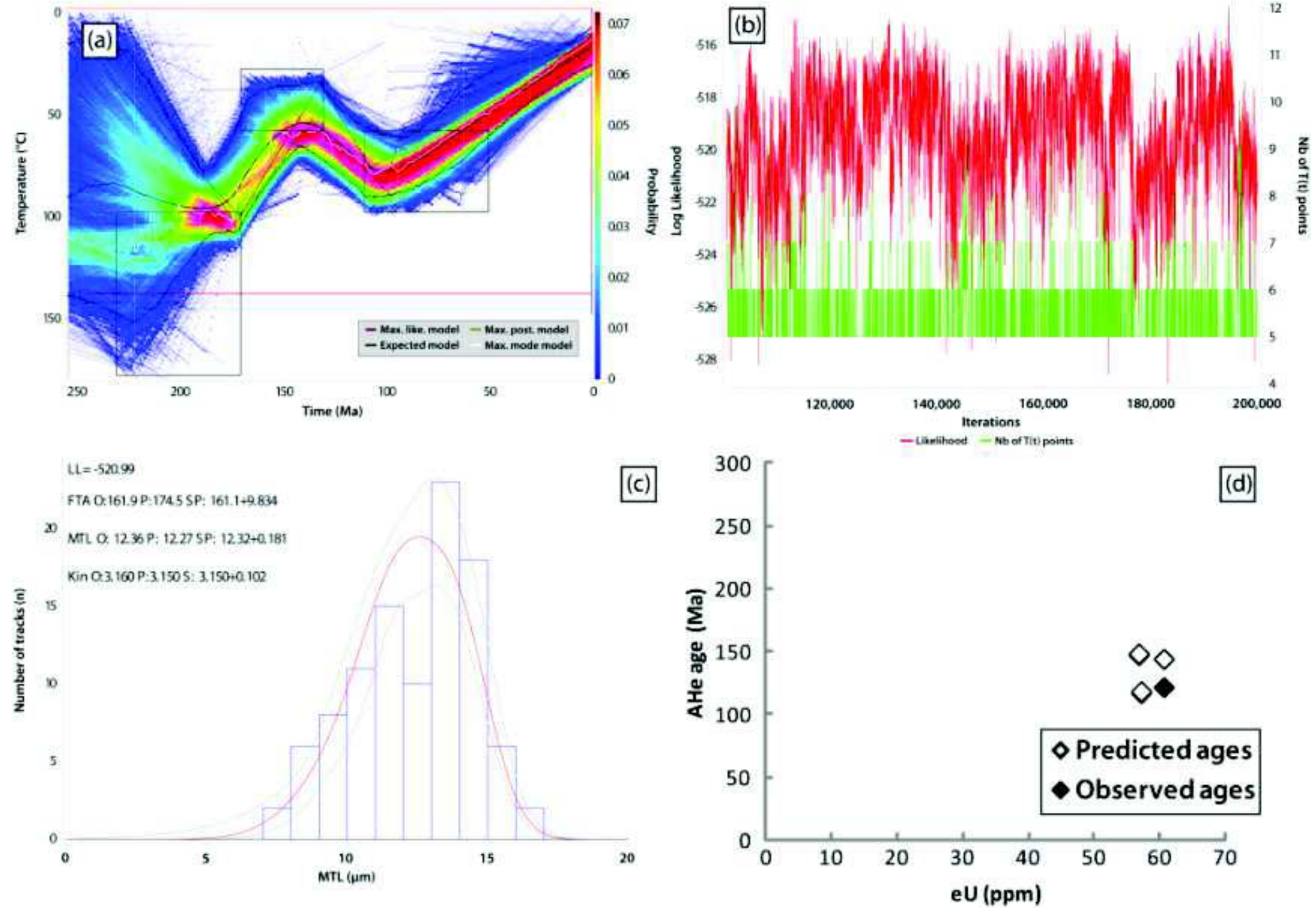

Figure S14: Inverse modeling for samples TEN1185. Same legend as in figures S2 and S4. 

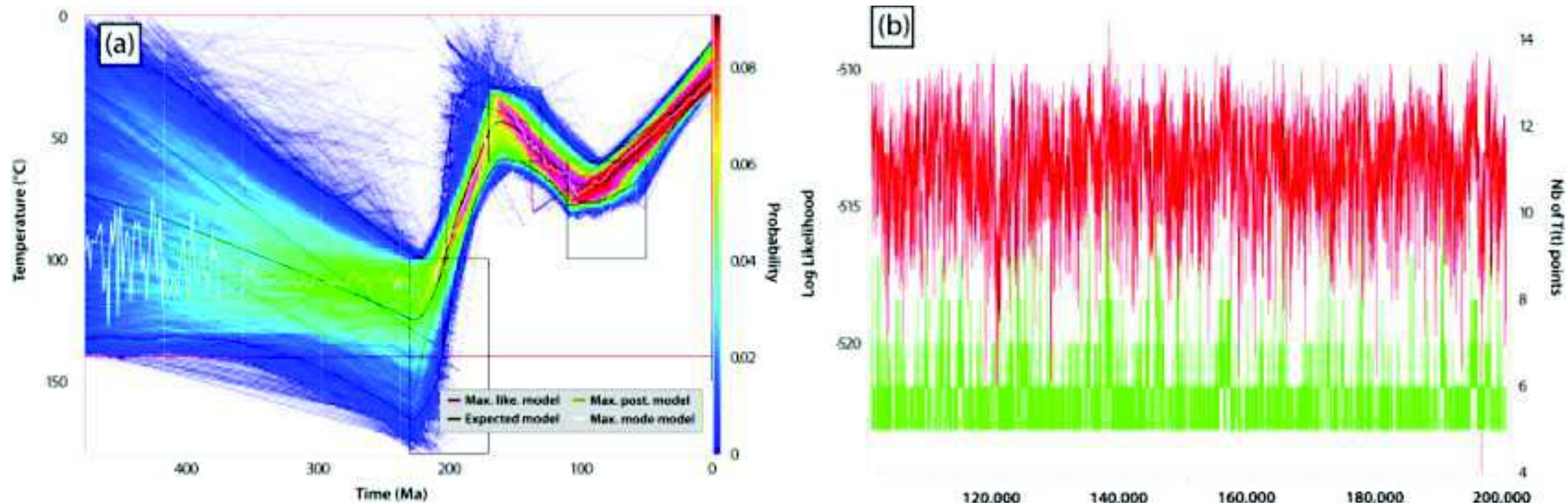

Time (Ma)
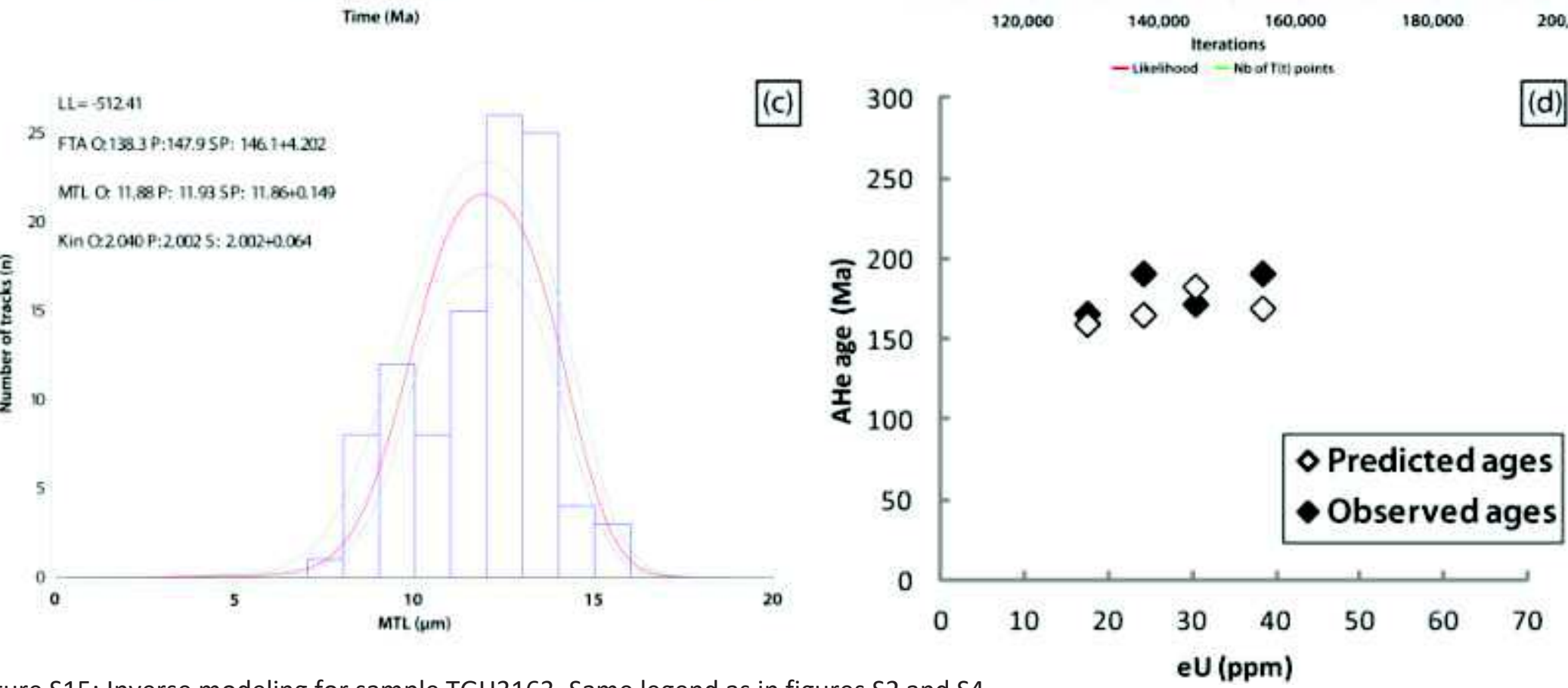

Figure S15: Inverse modeling for sample TGH3163. Same legend as in figures S2 and S4. 


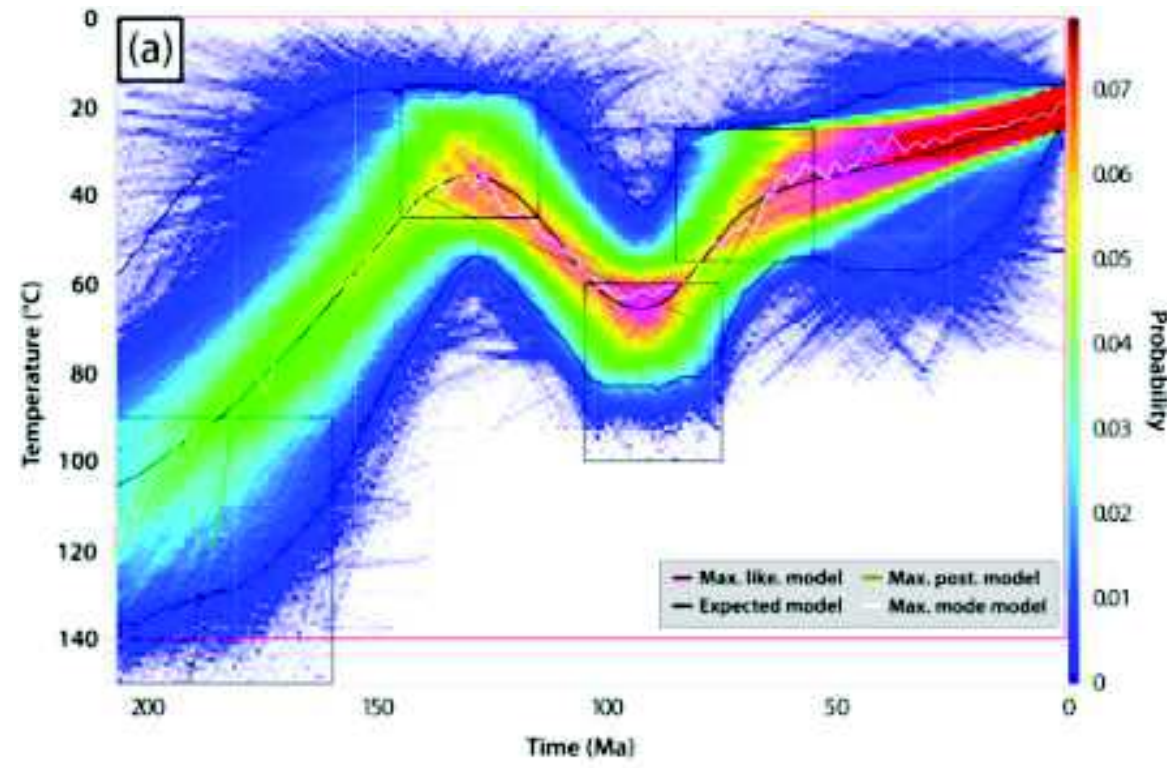

$25 \quad \mathrm{U}=45.46$

FTA OIX99P:14.35P: 135.1+9.627

20 Mrt 0.0000 P: $12325 P: 1217+0.360$

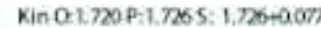

$\frac{\text { c }}{\frac{\text { g. }}{\underline{\underline{y}}}}{ }^{15}$

5

0

(c)

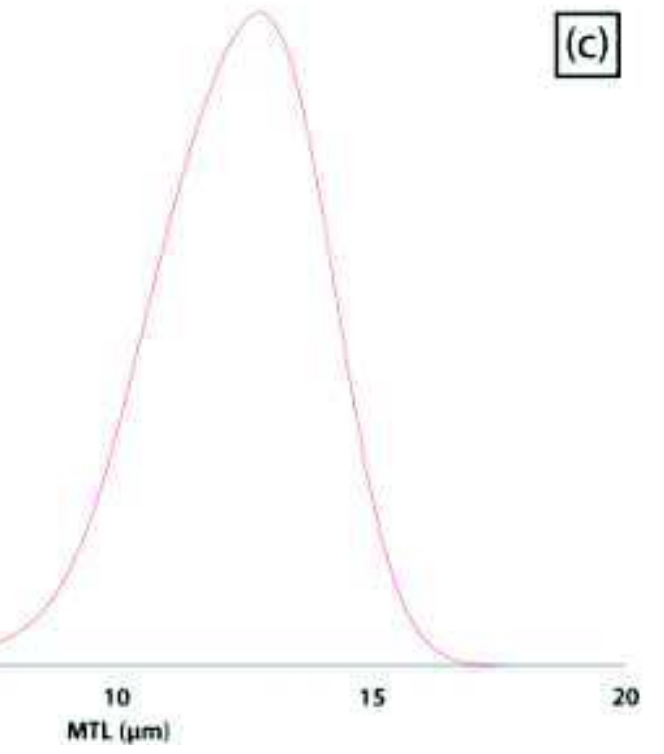

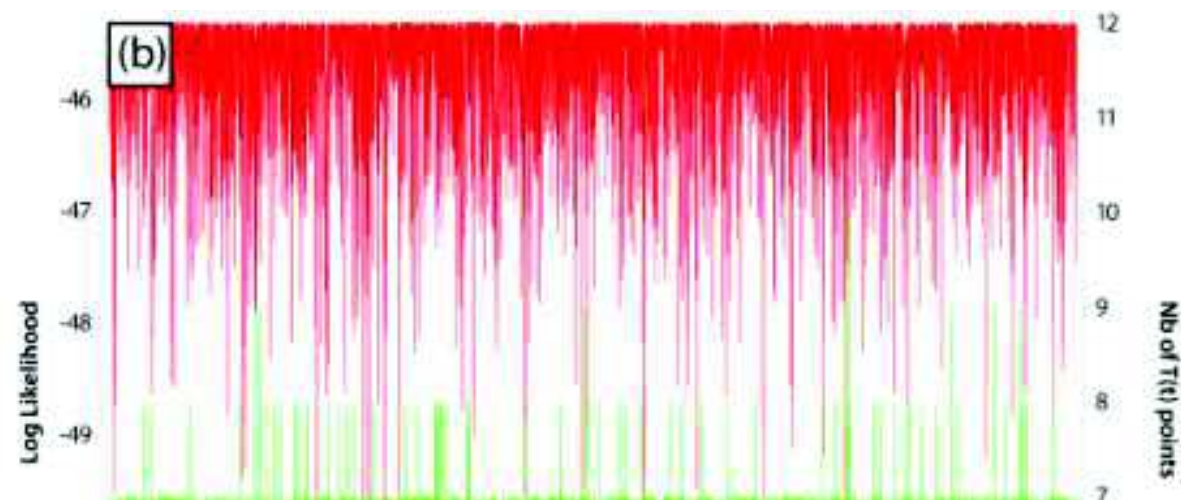

$-50$

51

120,000

$140,000 \underset{\text { Iterations }}{160,000}$
.

- Liketihoed - Nb of Tw peints

Figure S16: Inverse modeling for sample AG167. Same legend as in figure S2. 


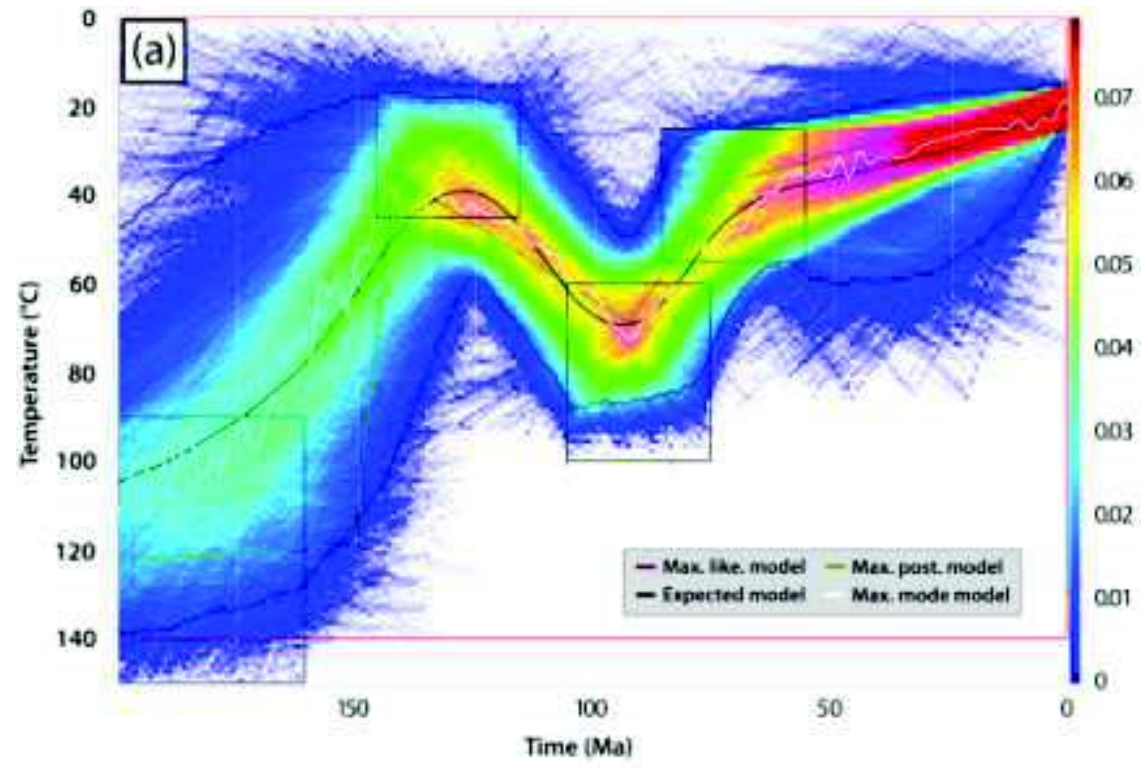

$4=-354$

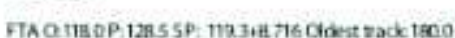

20 MTL O OCOOP: 1212SP: 1204+095

Kin 015015:1505:150:010

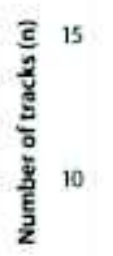

15

5

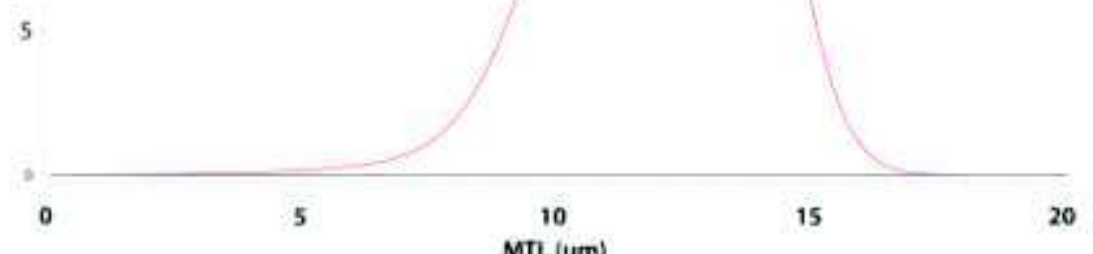

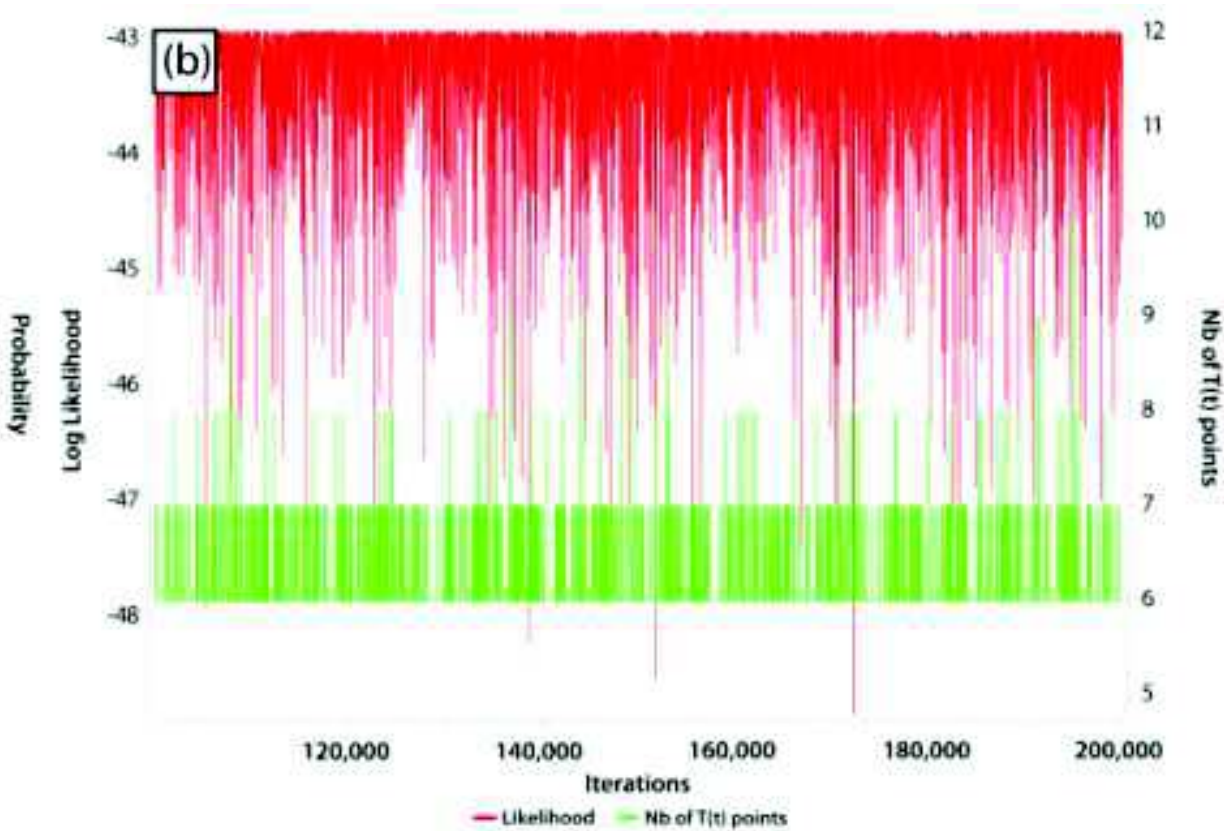

(c)

Figure S17: Inverse modeling for sample AG169. Same legend as in figure S2. 
Figure S18: Compositional chemical variations in apatites
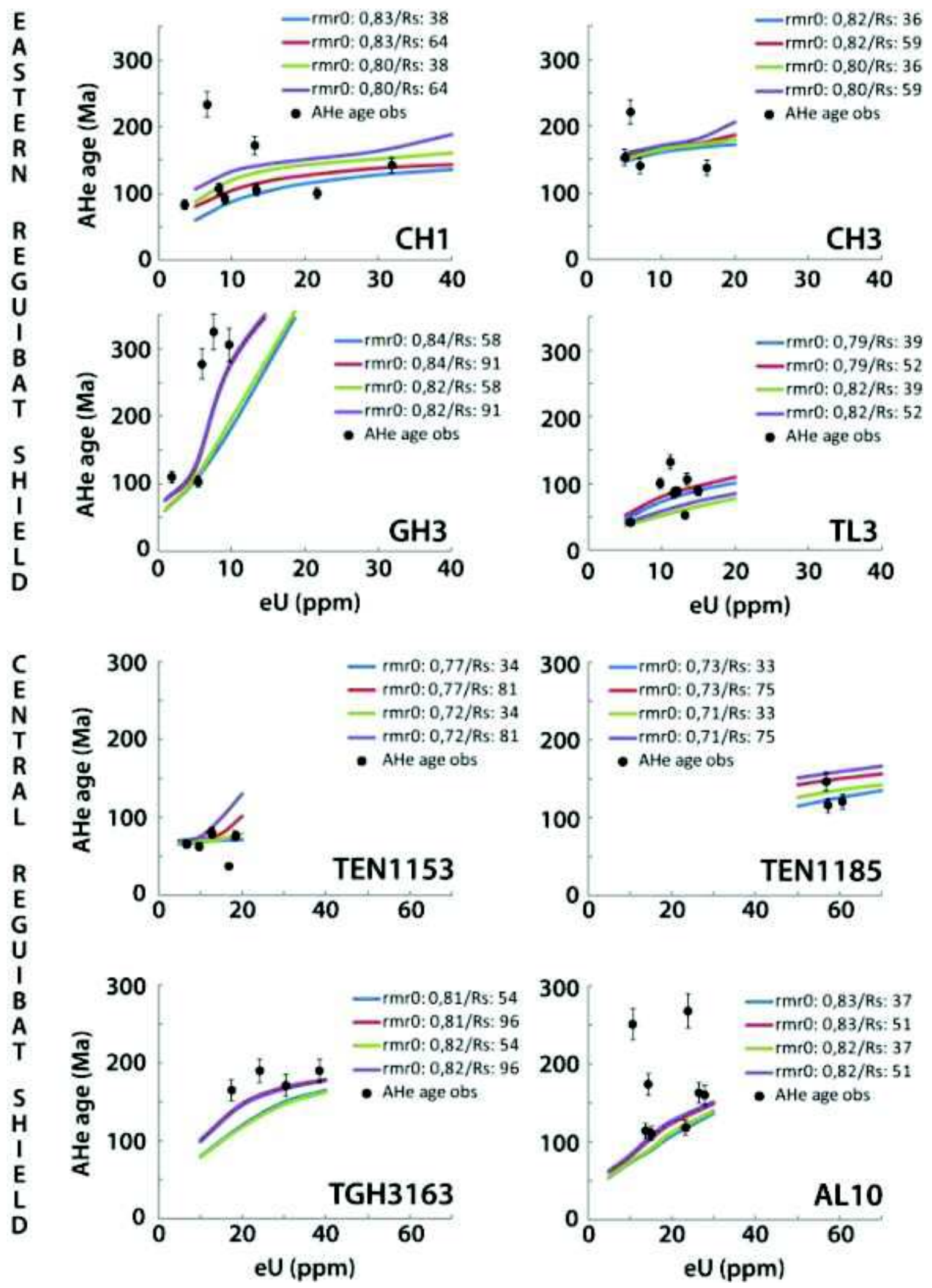
Table S1: AFT results* for the Reguibat Shield

Reguibat Central

\begin{tabular}{|c|c|c|c|c|c|c|c|c|c|c|c|c|}
\hline Sample & Rock-type & Location & $\begin{array}{l}\text { Elevation } \\
\text { (m) }\end{array}$ & $\rho_{s}$ & $\rho_{\mathrm{i}}$ & $\rho_{d}$ & $P\left(\chi^{2}\right) \%$ & Central age $(\mathrm{Ma}) \pm 1 \sigma$ & $\mathrm{U}(\mathrm{ppm})$ & MTL $(\mu \mathrm{m}) \pm \mathrm{se}$ & Std dev. & Dpar \\
\hline \multirow[t]{2}{*}{ TEN1153 } & gabbro & $10^{\circ} 30^{\prime} 36^{\prime \prime} \mathrm{W}$ & 216 & 0.759 & 0.333 & 6.14 & 73 & $256 \pm 21$ & 7 & $12.3 \pm 0.22$ & 2.3 & $2.89 \pm 0.29$ \\
\hline & & $24^{\circ} 1^{\prime} 12^{\prime \prime} \mathrm{N}$ & & 581 & 255 & 4738 & & 23 & & 102 & & \\
\hline \multirow[t]{2}{*}{ TEN1185 } & gabbro & $10^{\circ} 30^{\prime} 0^{\prime \prime} \mathrm{W}$ & 236 & 2.652 & 1.806 & 6.07 & 62 & $163 \pm 10$ & 36 & $12.4 \pm 0.21$ & 2.1 & $1.13 \pm 0.43$ \\
\hline & & $24^{\circ} 6^{\prime} 36^{\prime \prime} \mathrm{N}$ & & 875 & 596 & 4738 & & 23 & & 101 & & \\
\hline \multirow[t]{2}{*}{ TGH3163 } & granite & $9^{\circ} 52^{\prime} 48^{\prime \prime} \mathrm{W}$ & 305 & 1.546 & 1.219 & 5.99 & 44 & $139 \pm 9$ & 25 & $11.9 \pm 0.18$ & 1.8 & $1.95 \pm 0.12$ \\
\hline & & $24^{\circ} 52^{\prime} 48^{\prime \prime} \mathrm{N}$ & & 881 & 695 & 4738 & & 20 & & 101 & & \\
\hline \multirow[t]{2}{*}{ TGH4072A } & granite & $9^{\circ} 43^{\prime} 12^{\prime \prime} \mathrm{W}$ & 273 & 1.784 & 0.964 & 5.92 & 68 & $199 \pm 13$ & 20 & $12.4 \pm 0.15$ & 1.6 & $1.02 \pm 0.11$ \\
\hline & & $24^{\circ} 28^{\prime} 48^{\prime \prime} \mathrm{N}$ & & 883 & 477 & 4738 & & 20 & & 113 & & \\
\hline \multirow[t]{2}{*}{ TGH3111B } & granite & $9^{\circ} 22^{\prime} 12^{\prime \prime} \mathrm{W}$ & 252 & 3.246 & 2.598 & 6.611 & 65 & $150 \pm 8$ & 48 & $11.9 \pm 0.17$ & 1.7 & $1.63 \pm 0.06$ \\
\hline & & $24^{\circ} 00^{\prime} 00^{\prime \prime} \mathrm{N}$ & & 1097 & 878 & 6563 & & 20 & & 101 & & \\
\hline \multirow[t]{2}{*}{ TEN4065 } & microgranite & $10^{\circ} 1^{\prime} 47.00^{\prime \prime} \mathrm{W}$ & 258 & 6.444 & 4.462 & 6.595 & 8 & $172 \pm 13$ & 82 & $11.7 \pm 0.33$ & 2 & $2.06 \pm 0.53$ \\
\hline & & $24^{\circ} 20^{\prime} 23.00^{\prime \prime} \mathrm{N}$ & & 754 & 522 & 6563 & & 20 & & 35 & & \\
\hline \multirow[t]{2}{*}{ AL10 } & granodiorite & $7^{\circ} 7^{\prime} 5.15^{\prime \prime W}$ & 394 & 1.334 & 0.866 & 7.255 & 63 & $202 \pm 14$ & 15 & $12 \pm 0.23$ & 1.6 & $1.77 \pm 0.12$ \\
\hline & & $26^{\circ} 37^{\prime} 33.06^{\prime \prime} \mathrm{N}$ & & 675 & 438 & 6849 & & 20 & & 49 & & \\
\hline \multirow[t]{2}{*}{ YT7 } & monzogranite & 7²0'37.34"W & 384 & 1.862 & 1.394 & 6.825 & 72 & $166 \pm 8$ & 25 & $11.4 \pm 0.25$ & 1.8 & $1.60 \pm 0.19$ \\
\hline & & $26^{\circ} 28^{\prime} 59.39 " \mathrm{~N}$ & & 1380 & 1033 & 6849 & & 20 & & 49 & & \\
\hline
\end{tabular}

Reguibat West

\begin{tabular}{|c|c|c|c|c|c|c|c|c|c|c|c|c|}
\hline Sample & Rock-type & Location & $\begin{array}{c}\text { Elevation } \\
\text { (m) }\end{array}$ & $\rho_{s}$ & $\rho_{\mathrm{i}}$ & $\rho_{\mathrm{d}}$ & $P\left(x^{2}\right) \%$ & Central age $(\mathrm{Ma}) \pm 1 \sigma$ & $U$ (ppm) & $\mathrm{MTL}(\mu \mathrm{m}) \pm \mathrm{se}$ & Std dev. & Dpar \\
\hline \multirow[t]{2}{*}{ AOS2 } & syénite neph & $14^{\circ} 17^{\prime} \mathrm{W}$ & 400 & 1.1237 & 1.258 & 6.61 & 2 & $107 \pm 8$ & 23 & $11.8 \pm 0.24$ & 1.8 & $1.65 \pm 0.27$ \\
\hline & & $22^{\circ} 32^{\prime} \mathrm{N}$ & & 654 & 732 & 6528 & & 21 & & 56 & & \\
\hline AOS3 & syénite neph & $14^{\circ} 17^{\prime} \mathrm{W}$ & 400 & 1.899 & 1.772 & 6.58 & 63 & $128 \pm 6$ & 33 & $11.9 \pm 0.16$ & 1.6 & $1.65 \pm 0.27$ \\
\hline
\end{tabular}




\begin{tabular}{|c|c|c|c|c|c|c|c|c|c|c|c|c|}
\hline & & $22^{\circ} 32^{\prime} \mathrm{N}$ & & 1301 & 1241 & 6528 & & 21 & & 100 & & \\
\hline \multirow[t]{2}{*}{ AOS5 } & syénite neph & $14^{\circ} 17^{\prime} \mathrm{W}$ & 400 & 1.381 & 1.308 & 6.55 & 1 & $128 \pm 8$ & 24 & $11.8 \pm 0.19$ & 1.8 & $1.79 \pm 0.33$ \\
\hline & & $22^{\circ} 32^{\prime} \mathrm{N}$ & & 1153 & 1092 & 6528 & & 21 & & 92 & & \\
\hline \multirow{2}{*}{ SC11 } & granite & $14^{\circ} 21^{\prime} 38^{\prime \prime} \mathrm{W}$ & 293 & 0.85 & 0.627 & 6.5 & 50 & $160 \pm 11$ & 12 & $12.1 \pm 0.33$ & 1.8 & $1.75 \pm 0.28$ \\
\hline & & $22^{\circ} 34^{\prime} 36^{\prime \prime} \mathrm{N}$ & & 604 & 446 & 6528 & & 21 & & 32 & & \\
\hline \multirow[t]{2}{*}{ SC12 } & granite & $14^{\circ} 23^{\prime} 00^{\prime \prime} \mathrm{W}$ & 292 & 1.383 & 1.155 & 6.47 & 27 & $141 \pm 8$ & 22 & $12.2 \pm 0.17$ & 1.8 & $1.54 \pm 0.22$ \\
\hline & & $22^{\circ} 35^{\prime} 14^{\prime \prime} \mathrm{N}$ & & 1094 & 914 & 6528 & & 21 & & 108 & & \\
\hline \multirow[t]{2}{*}{$\mathrm{TCH} 7$} & granite & $15^{\circ} 6^{\prime} 37.25^{\prime \prime W}$ & 194 & 0.955 & 0.889 & 6.52 & 27 & $127 \pm 8$ & 17 & $9.4 \pm 0.27$ & 2 & $1.60 \pm 0.36$ \\
\hline & & $21^{\circ} 50^{\prime} 54.88^{\prime \prime} \mathrm{N}$ & & 916 & 853 & 6528 & & 21 & & 37 & & \\
\hline \multirow[t]{2}{*}{ SC5 } & granite & $14^{\circ} 29^{\prime} 38.00^{\prime \prime} \mathrm{W}$ & 284 & 1.04 & 0.839 & 6.657 & $<1$ & $156 \pm 15$ & 15 & $10.7 \pm 0.31$ & 1.7 & $1.63 \pm 0.10$ \\
\hline & & $22^{\circ} 40^{\prime} 50.00^{\prime \prime} \mathrm{N}$ & & 1131 & 913 & 6563 & & 20 & & 32 & & \\
\hline \multirow[t]{2}{*}{ SC9 } & granite & $14^{\circ} 18^{\prime} 56.00^{\prime \prime W}$ & 318 & 1.742 & 1.549 & 6.641 & $<1$ & $143 \pm 13$ & 28 & $11.2 \pm 0.35$ & 1.9 & $1.70 \pm 0.11$ \\
\hline & & $22^{\circ} 33^{\prime} 8.00^{\prime \prime} \mathrm{N}$ & & 866 & 770 & 6563 & & 20 & & 31 & & \\
\hline \multirow[t]{2}{*}{ SC15 } & granite & $14^{\circ} 28^{\prime} 52.00^{\prime \prime} \mathrm{W}$ & 282 & 0.6 & 0.425 & 6.626 & 10 & $175 \pm 16$ & 8 & - & - & $1.70 \pm 0.12$ \\
\hline & & $22^{\circ} 40^{\prime} 17.00^{\prime \prime} \mathrm{N}$ & & 482 & 341 & 6563 & & 20 & & - & - & \\
\hline \multirow[t]{2}{*}{ TAS29 } & gneiss & $15^{\circ} 32^{\prime} 55.96^{\prime \prime} \mathrm{W}$ & 110 & 0.743 & 0.778 & 6.586 & 11 & $115 \pm 6$ & 14 & $12.2 \pm 0.25$ & 1.8 & $1.70 \pm 0.12$ \\
\hline & & $20^{\circ} 59^{\prime} 34.10^{\prime \prime} \mathrm{N}$ & & 1047 & 1096 & 6849 & & 20 & & 51 & & \\
\hline \multirow[t]{2}{*}{ AG167 } & charnockite & $13^{\circ} 24^{\prime} 2.07^{\prime \prime W}$ & 233 & 0.218 & 0.195 & 6.73 & 74 & $137 \pm 12$ & 4 & - & - & $1.72 \pm 0.08$ \\
\hline & & $20^{\circ} 42^{\prime} 56.76^{\prime \prime} \mathrm{N}$ & & 323 & 289 & 6849 & & 20 & & - & - & \\
\hline \multirow[t]{2}{*}{ AG169 } & charnockite & $13^{\circ} 24^{\prime} 2.07^{\prime \prime W}$ & 237 & 0.201 & 0.207 & 6.682 & 93 & $118 \pm 10$ & 4 & - & - & $1.54 \pm 0.17$ \\
\hline & & $20^{\circ} 42^{\prime} 56.76^{\prime \prime} \mathrm{N}$ & & 309 & 319 & 6849 & & 20 & & - & - & \\
\hline \multirow[t]{2}{*}{ TAS233 } & volcanite & $15^{\circ} 32^{\prime} 55.96^{\prime \prime} \mathrm{W}$ & 110 & 0.68 & 0.651 & 6.634 & 87 & $126 \pm 7$ & 12 & $12.5 \pm 0.18$ & 1.8 & $1.63 \pm 0.15$ \\
\hline & & $20^{\circ} 59^{\prime} 34.10^{\prime \prime} \mathrm{N}$ & & 797 & 763 & 6849 & & 20 & & 102 & & \\
\hline
\end{tabular}




\section{Reguibat East}

\begin{tabular}{|c|c|c|c|c|c|c|c|c|c|c|c|c|}
\hline Sample & Rock-type & Location & $\begin{array}{c}\text { Elevation } \\
(\mathrm{m})\end{array}$ & $\rho_{\mathrm{s}}$ & $\rho_{\mathrm{i}}$ & $\rho_{\mathrm{d}}$ & $P\left(\chi^{2}\right) \%$ & Central age $(\mathrm{Ma}) \pm 1 \sigma$ & $U$ (ppm) & $\mathrm{MTL}(\mu \mathrm{m}) \pm \mathrm{se}$ & Std dev. & Dpar \\
\hline \multirow[t]{2}{*}{ IG3 } & rhyolite & $6^{\circ} 9^{\prime} 0.43^{\prime \prime} \mathrm{W}$ & 366 & 0.469 & 0.149 & 6.968 & 84 & $393 \pm 36$ & 3 & - & - & $1.66 \pm 0.16$ \\
\hline & & $26^{\circ} 6^{\prime} 22.40^{\prime \prime} \mathrm{N}$ & & 543 & 172 & 6849 & & 20 & & - & & \\
\hline \multirow[t]{2}{*}{$\mathrm{CH} 1$} & gabbrodiorite & $3^{\circ} 35^{\prime} 36.69 " \mathrm{~W}$ & 252 & 1.098 & 0.454 & 7.159 & 6 & $307 \pm 26$ & 8 & $11.5 \pm 0.21$ & 2.1 & $1.86 \pm 0.19$ \\
\hline & & $25^{\circ} 35^{\prime} 45.94^{\prime \prime} \mathrm{N}$ & & 862 & 356 & 6849 & & 20 & & 101 & & \\
\hline \multirow[t]{2}{*}{$\mathrm{CH} 2$} & gabbrodiorite & $3^{\circ} 35^{\prime} 36.69 " \mathrm{~W}$ & 252 & 3.105 & 1.516 & 7.112 & 18 & $264 \pm 21$ & 26 & $12 \pm 0.2$ & 1.7 & $1.99 \pm 0.17$ \\
\hline & & $25^{\circ} 35^{\prime} 45.94^{\prime \prime} \mathrm{N}$ & & 770 & 376 & 6849 & & 20 & & 69 & & \\
\hline \multirow[t]{2}{*}{$\mathrm{CH} 3$} & gabbrodiorite & $3^{\circ} 35^{\prime} 36.69^{\prime \prime} \mathrm{W}$ & 252 & 1.059 & 0.426 & 7.064 & 86 & $315 \pm 24$ & 7 & $11.5 \pm 0.29$ & 2.3 & $1.95 \pm 0.18$ \\
\hline & & $25^{\circ} 35^{\prime} 45.94^{\prime \prime} \mathrm{N}$ & & 686 & 276 & 6849 & & 20 & & 64 & & \\
\hline \multirow[t]{2}{*}{ GH3 } & trondhjemite & $6^{\circ} 3^{\prime} 54.77 " W$ & 360 & 1.177 & 0.41 & 7.016 & 6 & $359 \pm 27$ & 7 & $11.5 \pm 0.19$ & 1.9 & $1.76 \pm 0.16$ \\
\hline & & $25^{\circ} 29^{\prime} 36.53^{\prime \prime} \mathrm{N}$ & & 1130 & 394 & 6849 & & 20 & & 100 & & \\
\hline \multirow[t]{2}{*}{ DEG6 } & gabbro & $2^{\circ} 57^{\prime} 15.60^{\prime \prime} \mathrm{W}$ & 355 & 2.276 & 0.701 & 6.111 & 46 & $355 \pm 25$ & 12 & $11.2 \pm 0.41$ & 2.1 & $1.97 \pm 0.11$ \\
\hline & & $26^{\circ} 4^{\prime} 50.02^{\prime \prime} \mathrm{N}$ & & 1065 & 328 & 6849 & & 20 & & 27 & & \\
\hline \multirow[t]{2}{*}{$\mathrm{GH} 20$} & gabbro & $6^{\circ} 0^{\prime} 2.87^{\prime \prime} \mathrm{W}$ & 350 & 0.471 & 0.101 & 5.996 & 73 & $497 \pm 61$ & 2 & - & - & $1.75 \pm 0.13$ \\
\hline & & $25^{\circ} 32^{\prime} 51.89^{\prime \prime} \mathrm{N}$ & & 206 & 44 & 3012 & & 10 & & - & & \\
\hline \multirow[t]{2}{*}{ TL3 } & gabbro & $3^{\circ} 10^{\prime} 37.45^{\prime \prime} \mathrm{W}$ & 381 & 0.818 & 0.376 & 6.052 & 66 & $237 \pm 21$ & 8 & - & - & $2.12 \pm 0.19$ \\
\hline & & $27^{\circ} 21^{\prime} 31.99^{\prime \prime} \mathrm{N}$ & & 447 & 207 & 3012 & & 20 & & & & \\
\hline
\end{tabular}

* $\rho$ - density of tracks with $\mathrm{s}$ and $\mathrm{i}-$ spontaneous and induced densities in apatite crystals and the mica detector; $\mathrm{d}$ - tracks density of the neutron glass monitor (CN5); for $\rho d$ is written in italics the number of counted tracks. Densities are expressed in $10^{5} \mathrm{t} / \mathrm{cm}^{2}$. MTL - mean track length. Values in italics for central age and MTL are, respectively, the number of single-grain ages and the number of lengths measured. $1 \sigma$ is the standard deviation. Dpar corresponds to a kinetic factor determined for each sample (Barbarand et al., 2003). 
Table S2: AHe results* for the whole Reguibat Shield

\section{Reguibat Central}

\begin{tabular}{|c|c|c|c|c|c|c|c|c|c|c|c|}
\hline Name & Rs $(\mu \mathrm{m})$ & Weight $(\mu \mathrm{g})$ & FT & $4 \mathrm{He}(\mathrm{ncc} / \mathrm{g})$ & U (ppm) & Th (ppm) & Sm (ppm) & eU (ppm) & Age (Ma) & Age c. (Ma)* & s.d. \\
\hline $1185 \mathrm{C}$ & 52,1 & 3,11 & 0,756 & 678000 & 45,4 & 63,3 & NA & 60,6 & 104 & 138 & 11 \\
\hline 1185D & 74,5 & 10,33 & 0,849 & 868000 & 44,4 & 51,6 & - & 56,8 & 142 & 167 & 13 \\
\hline $1185 \mathrm{E}$ & 33,4 & 1,02 & 0,65 & 530000 & 39,4 & 74 & - & 57,1 & 86 & 133 & 11 \\
\hline $1153-A$ & 80,8 & 11,85 & 0,87 & 46201,6 & 3,8 & 11,9 & 7,0 & 6,7 & 57 & 66 & 5 \\
\hline 1153D & 34,4 & 1,17 & 0,715 & 120399,0 & 10,4 & 31,9 & 20,3 & 18,3 & 55 & 77 & 6 \\
\hline $1153-\mathrm{F}$ & 63,2 & 6,54 & 0,815 & 100000,8 & 7,6 & 20,3 & 9,5 & 12,6 & 66 & 81 & 6 \\
\hline 1153-H & 59 & 4,69 & 0,83 & 63086,4 & 11,2 & 22,6 & 12,5 & 16,7 & 31 & 38 & 3 \\
\hline 1153-I & 47,5 & 2,56 & 0,79 & 57756,0 & 5,5 & 16,8 & 13,3 & 9,6 & 50 & 63 & 5 \\
\hline 1153-J & 71,5 & 8,33 & 0,87 & 58868,8 & 5,6 & 17,0 & 12,9 & 9,7 & 50 & 58 & 5 \\
\hline 3163-A & 54,1 & 3,6 & 0,809 & 717183,1 & 37,7 & 1,9 & 27,2 & 38,3 & 155 & 191 & 15 \\
\hline 3163-E & 66 & 7,11 & 0,827 & 288616,5 & 16,9 & 1,4 & 17,6 & 17,4 & 137 & 166 & 13 \\
\hline 3163-I & 65,6 & 6,26 & 0,847 & 470679,8 & 17,8 & 25,6 & 24,6 & 24,1 & 162 & 191 & 15 \\
\hline $3163 G$ & 96,1 & 17,27 & 0,875 & 549045,6 & 25,0 & 22,0 & NA & 30,3 & 150 & 172 & 14 \\
\hline AL10-A & 46 & 2,4 & 0,755 & 405681,5 & 22,5 & 20,6 & 31,8 & 27,7 & 121 & 161 & 13 \\
\hline AL10-E & 39,3 & 1,18 & 0,701 & 675195,0 & 76,1 & 26,7 & 31,3 & 82,8 & 67 & 96 & 8 \\
\hline AL10-C & 50,5 & 3,53 & 0,765 & 229447,2 & 11,1 & 11,9 & 29,3 & 14,2 & 134 & 175 & 14 \\
\hline AL10-L & 44,1 & 1,57 & 0,679 & 1341456,8 & 34,3 & 31,1 & 59,4 & 42,2 & 263 & 388 & 31 \\
\hline AL10-J & 37,2 & 1,22 & 0,724 & 231868,3 & 7,9 & 10,0 & 37,4 & 10,5 & 182 & 252 & 20 \\
\hline AL10-I & 45,5 & 2,02 & 0,76 & 395904,9 & 22,4 & 14,9 & 41,0 & 26,3 & 124 & 164 & 13 \\
\hline AL10-B & 39 & 1,39 & 0,726 & 557702,2 & 20,6 & 11,6 & 37,5 & 23,7 & 195 & 269 & 21 \\
\hline
\end{tabular}




$\begin{array}{lllllllrrrrr}\text { AL10-K } & 37,9 & 1,28 & 0,717 & 145483,1 & 12,5 & 8,8 & 35,5 & 14,9 & 81 & 112 & 9 \\ \text { AL10-F } & 38,7 & 1,23 & 0,687 & 129286,7 & 9,5 & 15,8 & 44,8 & 13,6 & 79 & 115 & 9 \\ \text { AL10-G } & 39,9 & 1,23 & 0,707 & 1327362,4 & 32,4 & 26,5 & 65,3 & 39,3 & 280 & 396 & 32 \\ \text { AL10-H } & 42,6 & 1,58 & 0,713 & 236976,2 & 18,4 & 18,2 & 50,1 & 23,2 & 85 & 119 & 10\end{array}$

Reguibat West

\begin{tabular}{|c|c|c|c|c|c|c|c|c|c|c|c|}
\hline Name & $\mathrm{Rs}(\mu \mathrm{m})$ & Weight $(\mu \mathrm{g})$ & FT & $4 \mathrm{He}(\mathrm{ncc} / \mathrm{g})$ & U (ppm) & Th (ppm) & Sm (ppm) & eU (ppm) & Age (Ma) & Age c. $(\mathrm{Ma})^{*}$ & s.d. \\
\hline AOS3A & 57,7 & 4,14 & 0,781 & 379655,5 & 29,6 & 40,2 & 403,0 & 42,5 & 74 & 95 & 8 \\
\hline AOS3B & 48,3 & 2,56 & 0,786 & 368565,3 & 29,6 & 47,8 & 167,0 & 42,4 & 72 & 92 & 7 \\
\hline AOS3C & 58,4 & 5,02 & 0,803 & 168335,8 & 27,7 & 28,6 & 318,0 & 37,1 & 38 & 47 & 4 \\
\hline AOS3E & 55 & 3,82 & 0,806 & 317447,5 & 50,1 & 31,7 & 391,0 & 60,9 & 43 & 54 & 4 \\
\hline AOS5A & 54,4 & 3,77 & 0,843 & 17656,2 & 9,4 & 7,6 & 125,0 & 12,3 & 12 & 14 & 1 \\
\hline AOS5D & 48,7 & 2,8 & 0,736 & 59629,6 & 17,5 & 16,4 & 263,0 & 23,5 & 21 & 29 & 2 \\
\hline AOS5F & 48,2 & 2,27 & 0,754 & 175595,4 & 29,5 & 24,2 & 195,0 & 36,9 & 39 & 52 & 4 \\
\hline AOS2A & 58,6 & 4,48 & 0,783 & 252824,1 & 31,0 & 12,2 & 400,0 & 37,2 & 56 & 72 & 6 \\
\hline AOS2B & 62,7 & 6,65 & 0,812 & 219640,8 & 23,1 & 16,3 & 105,0 & 27,8 & 65 & 81 & 6 \\
\hline AOS2C & 47 & 2,35 & 0,777 & 47197,6 & 14,8 & 11,6 & 152,0 & 18,8 & 21 & 27 & 2 \\
\hline AOS2D & 43,8 & 1,96 & 0,756 & 77464,5 & 20,3 & 30,6 & 179,0 & 29,1 & 22 & 29 & 2 \\
\hline $\mathrm{TCH} 7 \mathrm{~A}$ & 49,4 & 2,8 & 0,802 & 194360,7 & 59,4 & 34,9 & 179,0 & 69,2 & 23 & 29 & 2 \\
\hline TCH7B & 68,7 & 8,03 & 0,833 & 137470,0 & 19,1 & 23,5 & 339,0 & 27,5 & 41 & 50 & 4 \\
\hline $\mathrm{TCH} 7 \mathrm{C}$ & 63,6 & 6,25 & 0,823 & 318644,3 & 43,4 & 11,1 & 229,0 & 47,9 & 55 & 67 & 5 \\
\hline TCH7D & 64,6 & 6,31 & 0,838 & 106663,8 & 13,5 & 8,9 & 267,0 & 17,8 & 50 & 59 & 5 \\
\hline
\end{tabular}




\begin{tabular}{|c|c|c|c|c|c|c|c|c|c|c|}
\hline SC5A & 46,9 & 2,61 & 0,756 & 209790,4 & 20,7 & 5,3 & 83,0 & 22,6 & 77 & 101 \\
\hline $\mathrm{SC} 5 \mathrm{C}$ & 56,6 & 4,35 & 0,802 & 26663,6 & 6,3 & 6,0 & 16,0 & 7,9 & 28 & 35 \\
\hline SC5D & 59,9 & 5,69 & 0,802 & 214046,7 & 26,8 & 10,6 & 14,9 & 29,5 & 60 & 75 \\
\hline SC9B & 59,9 & 5,4 & 0,809 & 59285,0 & 6,7 & 11,6 & 271,0 & 11,7 & 42 & 52 \\
\hline SC9D & 41,4 & 1,92 & 0,717 & 282683,0 & 26,7 & 37,2 & 274,0 & 37,9 & 62 & 86 \\
\hline SC9E & 45,8 & 2,35 & 0,761 & 606340,6 & 52,0 & 65,8 & 401,0 & 71,0 & 71 & 93 \\
\hline $\mathrm{SC} 11 \mathrm{C}$ & 50,3 & 3,01 & 0,782 & 18223,7 & 4,7 & 4,0 & 284,0 & 7,9 & 19 & 24 \\
\hline SC11D & 68 & 7,34 & 0,839 & 92903,5 & 7,3 & 13,5 & 228,0 & 12,4 & 62 & 74 \\
\hline SC11E & 53,2 & 2,98 & 0,775 & 157369,9 & 11,4 & 25,5 & 103,0 & 18,4 & 71 & 92 \\
\hline $\mathrm{SC} 11 \mathrm{~F}$ & 66,7 & 5,97 & 0,815 & 47092,6 & 8,2 & 2,9 & 266,0 & 11,0 & 35 & 43 \\
\hline $\mathrm{SC} 12 \mathrm{~A}$ & 41,6 & 1,65 & 0,749 & 108423,6 & 9,6 & 13,1 & 232,0 & 14,6 & 61 & 82 \\
\hline SC12D & 64 & 6,22 & 0,827 & 180770,1 & 19,1 & 9,4 & 241,0 & 23,3 & 64 & 78 \\
\hline $\mathrm{SC} 12 \mathrm{G}$ & 49,5 & 2,44 & 0,754 & 222394,6 & 22,1 & 12,8 & 141,0 & 26,3 & 48 & 63 \\
\hline $\mathrm{SC} 12 \mathrm{~F}$ & 52,3 & 2,8 & 0,77 & 151382,1 & 24,6 & 25,6 & 360,0 & 33,7 & 55 & 71 \\
\hline SC15A & 59,7 & 4,73 & 0,833 & 141643,9 & 10,6 & 16,3 & 382,0 & 17,5 & 67 & 80 \\
\hline SC15B & 56,5 & 3,7 & 0,782 & 16790,6 & 3,6 & 8,7 & 126,0 & 6,7 & 21 & 27 \\
\hline SC15F & 48,3 & 2,27 & 0,747 & 50901,3 & 5,6 & 19,5 & 90,0 & 11,0 & 39 & 52 \\
\hline SC15G & 56,5 & 3,99 & 0,828 & 234089,4 & 25,4 & 23,6 & 340,0 & 33,8 & 57 & 69 \\
\hline T233-B & 52,5 & 3,31 & 0,833 & 87654,0 & 9,1 & 2,6 & 12,9 & 9,8 & 74 & 89 \\
\hline T233-H & 55,5 & 4,01 & 0,803 & 163091,7 & 35,9 & 12,9 & 9,4 & 39,0 & 35 & 43 \\
\hline T233-D & 49,3 & 1,4 & 0,678 & 263063,3 & 27,0 & 7,2 & 30,6 & 29,0 & 75 & 111 \\
\hline T233-G & 58,8 & 4,58 & 0,822 & 55323,1 & 6,5 & 1,9 & 14,3 & 7,0 & 65 & 79 \\
\hline T233-F & 49,7 & 2,85 & 0,786 & 127884,5 & 12,9 & 3,2 & 12,5 & 13,7 & 77 & 98 \\
\hline TAS29A & 66,7 & 5,97 & 0,815 & 168827,7 & 14,1 & 5,4 & 12,1 & 15,4 & 90 & 111 \\
\hline
\end{tabular}




\begin{tabular}{|c|c|c|c|c|c|c|c|c|c|c|c|}
\hline TAS29B & 42,1 & 2 & 0,767 & 238975,6 & 16,0 & 16,9 & 27,9 & 20,1 & 98 & 127 & 10 \\
\hline TAS29C & 50 & 2,57 & 0,758 & 196139,6 & 19,6 & 4,9 & 10,1 & 20,8 & 78 & 102 & 8 \\
\hline TAS29D & 56,9 & 3,14 & 0,748 & 196541,4 & 10,7 & 3,9 & 13,1 & 11,7 & 138 & 185 & 15 \\
\hline TAS29E & 71,4 & 7,22 & 0,84 & 57789,0 & 7,2 & 1,8 & 6,5 & 7,6 & 62 & 74 & 6 \\
\hline
\end{tabular}

\section{Reguibat East}

\begin{tabular}{|c|c|c|c|c|c|c|c|c|c|c|c|}
\hline Name & $\mathrm{Rs}(\mu \mathrm{m})$ & Weight $(\mu \mathrm{g})$ & FT & 4He(ncc/g) & U (ppm) & Th (ppm) & Sm (ppm) & eU (ppm) & Age (Ma) & Age c. (Ma)* & s.d. \\
\hline $\mathrm{CH} 1-\mathrm{A}$ & 47,3 & 2,43 & 0,789 & 79475,1 & 7,2 & 6,9 & 5,3 & 9,0 & 74 & 93 & 7 \\
\hline $\mathrm{CH} 1-\mathrm{B}$ & 56,4 & 4,13 & 0,809 & 28513,1 & 2,7 & 3,2 & 1,4 & 3,5 & 68 & 84 & 7 \\
\hline $\mathrm{CH} 1-\mathrm{C}$ & 49,4 & 2,68 & 0,802 & 48729,7 & 13,1 & 11,1 & 5,3 & 15,8 & 26 & 32 & 3 \\
\hline CH1-D & 40,2 & 1,45 & 0,751 & 205297,8 & 10,1 & 12,5 & 5,6 & 13,1 & 130 & 173 & 14 \\
\hline $\mathrm{CH} 1-\mathrm{F}$ & 38,8 & 1,31 & 0,754 & 127741,1 & 11,0 & 9,6 & 3,4 & 13,3 & 80 & 106 & 8 \\
\hline $\mathrm{CH} 1-\mathrm{G}$ & 64 & 6,37 & 0,831 & 88950,2 & 6,2 & 8,5 & 5,1 & 8,2 & 90 & 108 & 9 \\
\hline $\mathrm{CH} 1-\mathrm{H}$ & 37,9 & 1,28 & 0,717 & 392039,3 & 26,1 & 23,4 & 6,0 & 31,8 & 102 & 143 & 11 \\
\hline CH1-J & 50,6 & 3,96 & 0,761 & 141712,3 & 5,0 & 6,5 & 4,5 & 6,6 & 178 & 234 & 19 \\
\hline $\mathrm{CH} 1-\mathrm{K}$ & 40,7 & 1,74 & 0,723 & 190623,3 & 19,0 & 10,3 & 14,9 & 21,6 & 73 & 101 & 8 \\
\hline $\mathrm{CH} 3-\mathrm{C}$ & 50,5 & 3,04 & 0,789 & 119938,2 & 4,2 & 5,9 & 3,7 & 5,7 & 175 & 222 & 18 \\
\hline $\mathrm{CH} 3-\mathrm{F}$ & 35,5 & 0,96 & 0,717 & 191786,5 & 13,4 & 11,3 & 4,2 & 16,1 & 99 & 138 & 11 \\
\hline $\mathrm{CH} 3-\mathrm{A}$ & 54,7 & 4,25 & 0,79 & 93992,9 & 5,7 & 5,5 & 3,2 & 7,0 & 111 & 141 & 11 \\
\hline $\mathrm{CH} 3-\mathrm{G}$ & 59,2 & 6,11 & 0,793 & 71843,0 & 3,7 & 5,0 & 2,7 & 4,9 & 122 & 153 & 12 \\
\hline $\mathrm{GH} 3 \mathrm{~A}$ & 66,1 & 7,49 & 0,823 & 292746,2 & 8,1 & 5,6 & 12,7 & 9,6 & 253 & 307 & 25 \\
\hline GH3B & 91,1 & 21,74 & 0,876 & 172995,7 & 4,7 & 4,6 & 6,4 & 5,9 & 243 & 278 & 22 \\
\hline $\mathrm{GH} 3-\mathrm{C}$ & 71,5 & 8,99 & 0,842 & 56806,1 & 4,5 & 3,5 & 8,9 & 5,4 & 88 & 104 & 8 \\
\hline GH3-E & 57,9 & 4,06 & 0,784 & 230520,3 & 6,5 & 3,8 & 10,8 & 7,5 & 256 & 326 & 26 \\
\hline GH3-F & 99 & 19,03 & 0,883 & 21444,4 & 1,7 & 0,4 & 2,2 & 1,8 & 98 & 111 & 9 \\
\hline
\end{tabular}




\begin{tabular}{|c|c|c|c|c|c|c|c|c|c|c|c|}
\hline IG3-C & 43,8 & 1,72 & 0,722 & 332846,2 & 18,1 & 18,9 & 44,7 & 23,0 & 120 & 166 & 13 \\
\hline IG3-E & 39,4 & 1,31 & 0,686 & 191182,1 & 5,0 & 10,0 & 48,9 & 7,8 & 203 & 295 & 24 \\
\hline IG3-F & 36,7 & 0,99 & 0,675 & 118582,6 & 3,8 & 10,9 & 47,2 & 6,8 & 146 & 216 & 17 \\
\hline IG3-G & 40,6 & 1,56 & 0,741 & 91106,9 & 3,7 & 4,9 & 38,8 & 5,1 & 147 & 198 & 16 \\
\hline IG3-I & 40,4 & 1,67 & 0,721 & 187725,0 & 3,9 & 5,5 & 49,9 & 5,6 & 277 & 384 & 31 \\
\hline TL3-L & 41,1 & 1,58 & 0,745 & 131554,4 & 6,3 & 18,8 & 29,8 & 11,1 & 99 & 133 & 11 \\
\hline TL3-B & 49,4 & 2,68 & 0,803 & 66784,2 & 8,8 & 17,0 & 23,8 & 13,1 & 42 & 53 & 4 \\
\hline TL3-C & 41,3 & 1,57 & 0,778 & 73141,8 & 9,2 & 43,5 & 27,0 & 19,8 & 31 & 40 & 3 \\
\hline TL3-D & 39 & 1,44 & 0,717 & 86327,5 & 6,3 & 20,9 & 33,8 & 11,6 & 62 & 87 & 7 \\
\hline TL3-F & 41,4 & 1,92 & 0,717 & 123516,5 & 7,1 & 25,1 & 35,2 & 13,4 & 77 & 107 & 9 \\
\hline TL3-G & 43,5 & 1,98 & 0,745 & 95782,6 & 6,4 & 21,9 & 34,3 & 12,0 & 67 & 89 & 7 \\
\hline TL3-J & 52 & 3,29 & 0,797 & 93130,9 & 5,4 & 17,1 & 25,4 & 9,7 & 80 & 101 & 8 \\
\hline TL3-H & 47 & 2,35 & 0,777 & 123871,0 & 8,0 & 27,5 & 36,9 & 14,9 & 69 & 89 & 7 \\
\hline TL3-K & 46,6 & 2,77 & 0,746 & 21915,9 & 3,6 & 8,2 & 19,6 & 5,7 & 32 & 43 & 3 \\
\hline GH2O-A & 36,4 & 1,14 & 0,702 & 58542,3 & 5,8 & 5,2 & 129,6 & 8,1 & 60 & 85 & 7 \\
\hline GH2O-C & 37,4 & 1,28 & 0,703 & 74174,8 & 12,9 & 6,9 & 26,5 & 14,7 & 42 & 59 & 5 \\
\hline GH2O-D & 37,4 & 1,28 & 0,703 & 54325,7 & 5,9 & 5,1 & 31,4 & 7,3 & 61 & 87 & 7 \\
\hline GH2O-F & 41,1 & 1,58 & 0,745 & 34723,6 & 4,1 & 5,3 & 30,5 & 5,7 & 51 & 68 & 5 \\
\hline $\mathrm{GH} 20-\mathrm{H}$ & 35,1 & 1,22 & 0,663 & 37173,2 & 9,5 & 6,2 & 37,8 & 11,2 & 27 & 41 & 3 \\
\hline GH2O-G & 39,2 & 1,52 & 0,711 & 54027,8 & 11,1 & 7,0 & 34,3 & 13,1 & 34 & 48 & 4 \\
\hline
\end{tabular}

* Rs (sphere equivalent radius) and $\mathrm{F}_{T}$ (ejection factor) have been calculated using the developed procedure of Gautheron \& Tassan-Got (2010) and Ketcham et al. (2011). eU (effective uranium) has been calculated with the formula $[\mathrm{eU}]=[\mathrm{U}]+0.24^{*}[\mathrm{Th}]+0.008^{*}[\mathrm{Sm}]$. "Age c." means (U-Th-Sm)/He age corrected from alpha-ejection with the $F_{T}$. The error is estimated to be a maximum of $8 \%$. 
Table S3: Results from forward modeling of central RS samples

$\begin{array}{ccccccc}\begin{array}{c}\text { Equivalent sphere radius }=55 \\ \text { eU (ppm) }\end{array} & \text { AHe age (Ma) } & \text { HT1 } & \text { HT2 } & \text { HT3 } & \text { HT4 } & \text { HT5 } \\ 5 & 45 & 37 & 42 & 42 & 45 & 79 \\ 10 & 55 & 46 & 58 & 55 & 54 & 85 \\ 15 & 78 & 54 & 81 & 81 & 61 & 88 \\ 20 & 125 & 63 & 106 & 112 & 67 & 90 \\ 30 & 165 & 82 & 137 & 151 & 75 & 92 \\ 40 & 180 & 99 & 152 & 171 & 81 & 94 \\ 60 & 190 & 120 & 167 & 189 & 90 & 95\end{array}$

HT: Thermal History

eU: efficient Uranium 